\title{
ALTERAÇÕES NAS PROPRIEDADES QUÍMICAS DE UM ARGISSOLO ADUBADO COM LODO DE ESGOTO E DESENVOLVIMENTO E ACÚMULO DE NUTRIENTES EM PLANTAS DE MILHO
}

\section{MARCIA APARECIDA SIMONETE}

Engenheiro Agrônomo

Orientador: Prof. Dr. JORGE DE CASTRO KIEHL

Tese apresentada à Escola Superior de Agricultura "Luiz de Queiroz", Universidade de São Paulo, para obtenção do título de Doutor em Agronomia, Área de Concentração: Solos e Nutrição de Plantas.

\author{
PIRACICABA \\ Estado de São Paulo - Brasil \\ Março- 2001
}


Dados Internacionais de Catalogação na Publicação (CIP)

DIVISĀO DE BIBLIOTECA E DOCUMENTAÇĀO - Campus "Luiz de Queiroz"/USP

\section{Simonete, Márcia Aparecida}

Alteraçōes nas propriedades químicas de um argissolo adubado com lodo de esgoto e desenvolvimento e acúmulo de nutrientes em plantas de milho / Márcia Aparecida Simonete. - - Piracicaba, 2001.

$89 \mathrm{p}$.

Tese (doutorado) - Escola Superior de Agricultura Luiz de Queiroz, 2001.

Bibliografia.

1. Adubação 2. Dosagem 3. Estufa 4. Lodo de esgoto 5. Matéria orgânica 6. Metal pesado 7. Milho 8. Propriedade fisico-química do solo I. Título

CDD 633.15 
A DEUS, por estar presente em todos momentos da minha humilde existência,

\section{OFEREÇO.}

Aos meus pais ADELFO e VITALINA SIMONETE;

Às minhas irmãs MARIA HELENA, MARILZA e MARILDA;

Aos meus sobrinhos JULIANO, MATHEUS, LARÁ e GABRIEL; 


\section{AGRADECIMENTOS}

Ao Prof. Dr. Jorge de Castro Kiehl, pela orientação, amizade e confiança à mim depositada durante o desenvolvimento deste trabalho.

À Coordenação do Curso de Pós-Graduação em Solos e Nutrição de Plantas da ESALQ/USP, pela oportunidade concedida.

À CAPES pela concessão da bolsa de estudo.

À “irmã" Claudia Teixeira, não existem palavras que eu possa expressar meus agradecimentos.

Aos amigos Silvino Moreira, Aderbal Rocha, Cristiano Andrade, Janaina Braga do Carmo, Glaucia Anti, Mônica Camargo, Luiz Pedro Plese, Marco Nogueira, Walcylene Pereira pelos momentos alegres, companheirismo e amizade.

Às secretárias Geovana, Nancy e Márcia, pela consideração, gentileza e atenção constantes.

Aos funcionários do Departamento de Solos e Nutrição de Plantas da ESALQ/USP - Àrea de Solos, pela importante colaboração na execução das análises de laboratório.

À todos os colegas do Curso de Pós-Graduação da ESALQ/USP, pela convivência agradável.

Finalmente à todos aqueles que direta ou indiretamente colaboraram para a realização deste trabalho, o meu sincero agradecimento. 


\section{SUMÁRIO}

Página

LISTA DE FIGURAS....................................................................................... vi

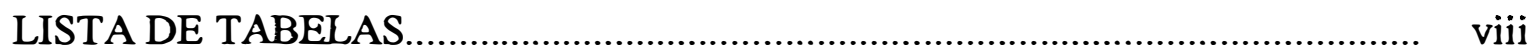

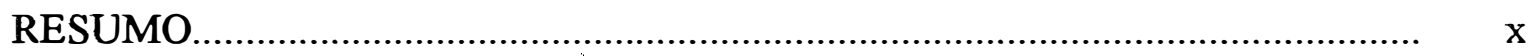

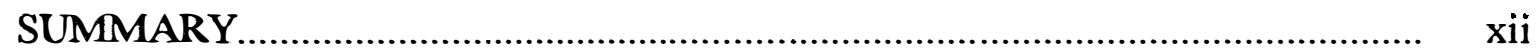

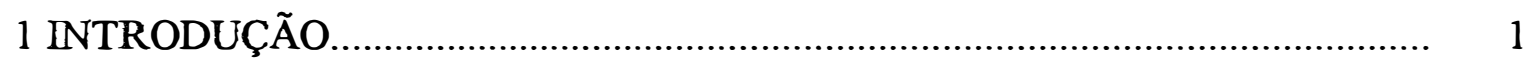

2 REVISÃO DE LITERATURA..........................................................................

2.1 Caracterização do lodo de esgoto........................................................................ 3

2.2 Alterações nas propriedades químicas do solo com a adição de lodo de esgoto... 5

2.3 Lodo de esgoto como fertilizante......................................................................

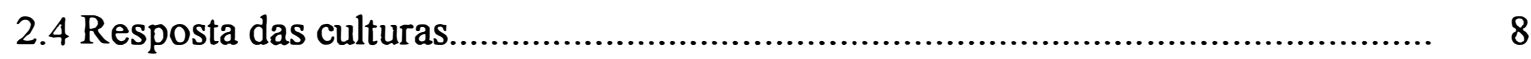

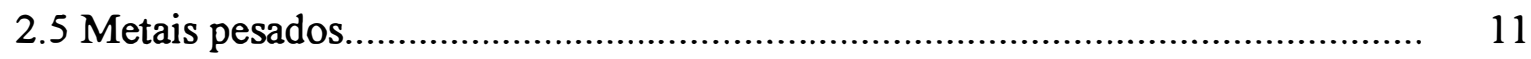

2.5.1 Acúmulo de metais no solo e nas plantas........................................................ 12

2.5.2 Avaliação da fitodisponibilidade de metais....................................................... 14

2.5.3 Aspectos de legislação.................................................................................. 18

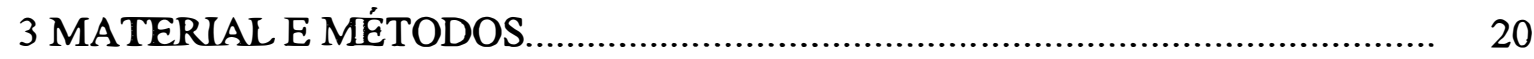

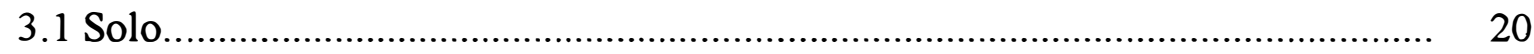

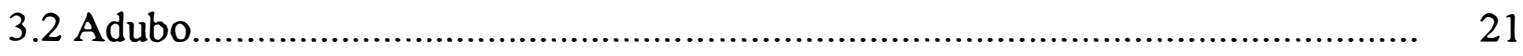

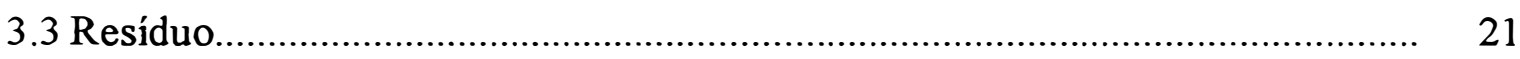

3.4 Tratamentos e delineamento experimental.................................................... 23

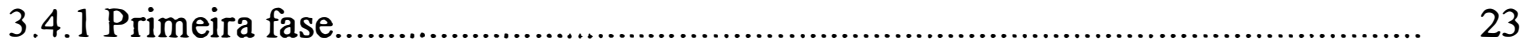

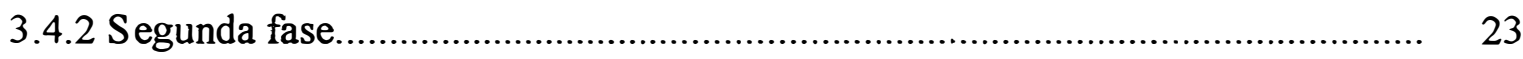

3.5 Instalação do experimento ........................................................................... 24

3.5.1 Primeira fase

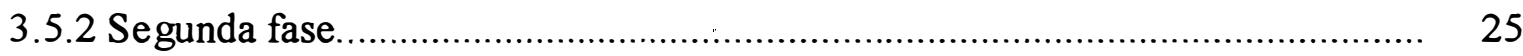




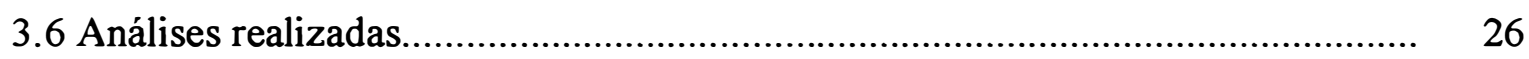

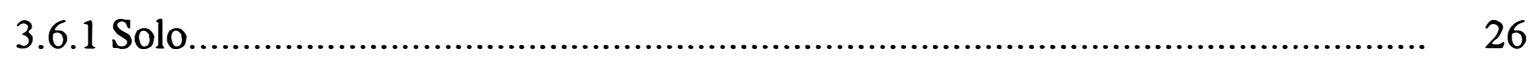

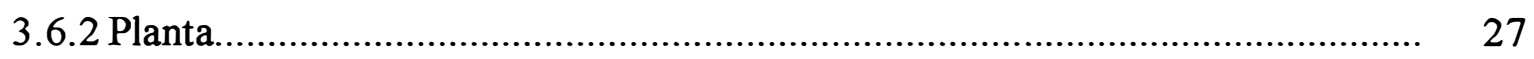

3.7 Tratamento estatístico dos resultados obtidos.................................................... 28

4 RESULTADOS E DISCUSSÃO.................................................................. 31

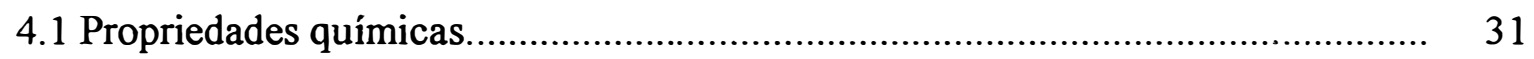

4.1.1 Matéria orgânica, $\mathrm{pH}$, alumínio trocável e saturação por alumínio.................... 31

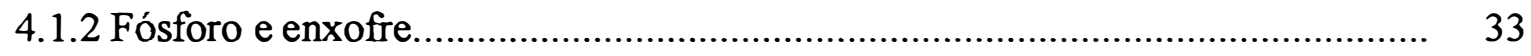

4.1.3 Cátions trocáveis.................................................................................. 35

4.1.4 Soma de bases (SB), $\mathrm{H}+\mathrm{Al}$, capacidade de roca de cátions (CTC a pH 7)

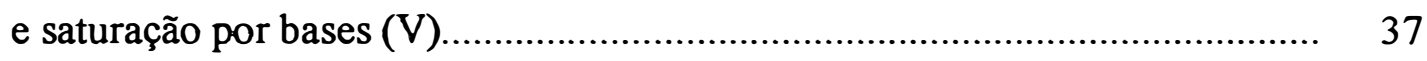

4.2 Metais no solo e na planta.............................................................................. 39

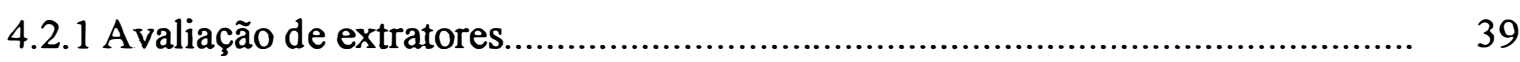

4.2.2 Acúmulo de metais nas plantas ...................................................................... 47

4.2.3 Fitodisponibilidade de metais....................................................................... 51

4.3 Produção de matéria seca e acúmulo de macronutrientes.................................... 53

4.3.1 Produção de matéria seca................................................................................. 53

4.3.2 Acúmulo de macronutrientes..................................................................... 56

4.3.2.1 Nitrogênio ...................................................................................... 56

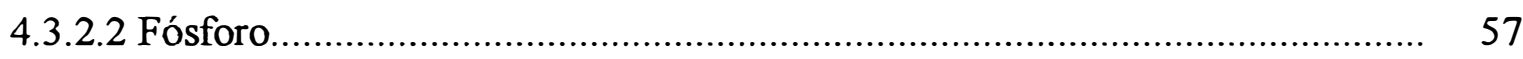

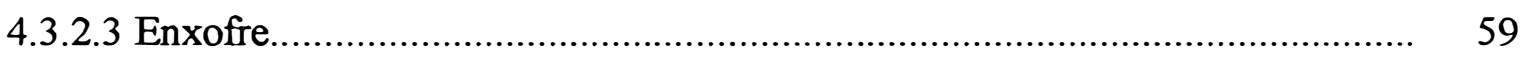

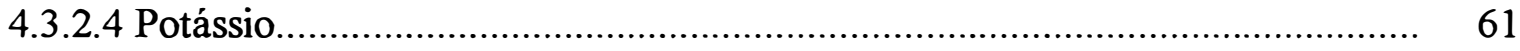

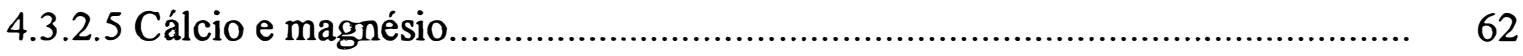

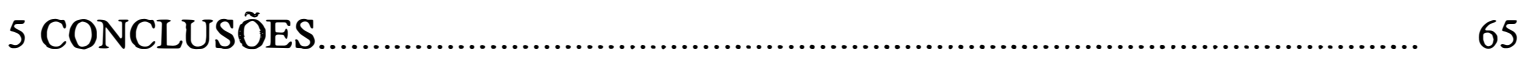

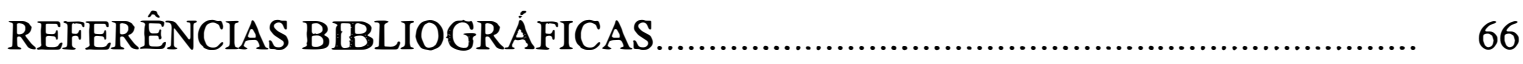

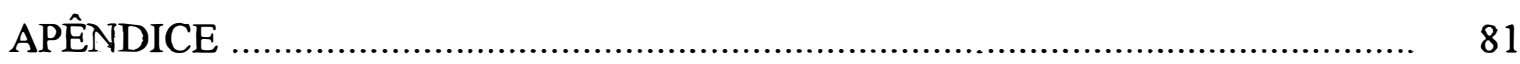




\section{LISTA DE FIGURAS}

Página

1 Teores de matéria orgânica (MO), valores de $\mathrm{pH}, \mathrm{Al}$-tocável $(\mathrm{Al})$ e saturação por alumínio (m) nas amostras de terra, em função da aplicação de doses de lodo de esgoto, após 30 dias de incubação

2 Teores de fósforo e enxofre $\left(\mathrm{S}^{-} \mathrm{SO}_{4}\right)$ nas amostras de terra, em função das doses de lodo de esgoto, após 30 dias de incubação.

3 Teores trocáveis de potássio, cálcio, magnésio e sódio nas amostras de terra, em função da adição de doses de lodo de esgoto, após 30 dias de incubação....

4 Soma de bases (SB), $\mathrm{H}+\mathrm{Al}$, capacidade de troca de cátions potencial (CTC) e saturação por bases nas amostras de terra, em função da aplicação de doses de lodo de esgoto, após 30 dias de incubação

5 Teores de ferro extraídos pelos extratores HCL 0,1 mol L ${ }^{-1}(\mathrm{HCl})$, Mehlich-3 (M-3) e DTPA em função da aplicação de lodo.

6 Teores de manganês extraídos pelos extratores HCL 0,1 mol $\mathrm{L}^{-1}$ (HCl), Mehlich-3 (M-3) e DTPA em função da aplicação de lodo

7 Teores de cobre extraídos pelos extratores HCL $0,1 \mathrm{~mol} \mathrm{~L}^{-1}(\mathrm{HCl})$, Mehlich-3 (M-3) e DTPA em função da aplicação de lodo.

8 Teores de zinco extraídos por HCL 0,1 mol L ${ }^{-1}(\mathrm{HCl})$, Mehlich-3 (M-3) e DTPA em função da aplicação de doses de lodo de esgoto

9 Ferro acumulado pela parte aérea das plantas em função da aplicação de doses de lodo.

10 Cobre acumulado pela parte aérea das plantas em função da aplicação de doses de lodo 
11 Manganês acumulado pela parte aérea das plantas em função da aplicação de doses de lodo.

12 Zinco acumulado pela parte aérea das plantas em função da aplicação de doses de lodo, complementadas ou não com potássio.

13 Produção de matéria seca da parte aérea das plantas de milho, em função da aplicação de doses de lodo complementadas ou não com potássio.

14 Nitrogênio acumulado pela parte aérea das plantas em função da aplicação de doses de lodo, complementadas ou não com potássio mineral.

15 Quantidade de fósforo acumulada na parte aérea das plantas em função da aplicação de doses de lodo, complementadas ou não com potássio mineral......

16 Quantidade de enxofre $\left(\mathrm{S}_{-} \mathrm{SO}_{4}\right)$ acumulado na parte aérea das plantas em função da aplicação de doses de lodo, complementadas ou não com potássio mineral.

17 Potássio acumulado na parte aérea das plantas em função da aplicação de doses de lodo, complementadas ou não com potássio mineral.

18 Quantidade de cálcio acumulado pela parte aérea das plantas em função da aplicação de doses de lodo, complementadas ou não com potássio.

19 Quantidade de magnésio acumulado pela parte aérea das plantas em função da aplicação de doses de lodo, complementadas ou não com potássio. 


\section{LISTA DE TABELAS}

Página

1 Características químicas de lodos de esgoto (base seca) utilizados em alguns experimentos conduzidos no Estado de São Paulo.

2 Limites de metais pesados estabelecidos pela EPA para a utilização de lodo de esgoto em solos agrícolas

3 Teores totais de alguns metais nos adubos superfosfato simples, cloreto de potássio e uréia utilizados no experimento.

4 Caracterização química da amostra de lodo utilizada no experimento.

5 Quantidades de macronutrientes adicionados ao solo em função da aplicação de doses de lodo de esgoto.

6 Quantidades de metais adicionados ao solo em função da aplicação de doses de lodo de esgoto.

7 Esquema de análise de variância para as variáveis $\mathrm{MO}, \mathrm{SB}, \mathrm{CTC}, \mathrm{V} \%, \mathrm{~m} \%$, $\mathrm{H}+\mathrm{Al}, \mathrm{Al}, \mathrm{Na}$, macronutrientes e metais determinados no solo, após período de incubação

8 Esquema de análise de variância para a variável método de extração de metais avaliado, após período de incubação.

9 Esquema de análise de variância para as variáveis produção de matéria seca, macronutrientes e metais acumulados pelas plantas.

10 Quantidades de metais adicionadas às amostras de terra em função da adição das doses de lodo de esgoto.

11 Teores de ferro, manganês, cobre e zinco removidos por diferentes extratores em função da aplicação de doses de lodo de esgoto. 
12 Coeficiente de correlação linear simples para os teores de ferro, manganês, cobre e zinco entre os extratores $\mathrm{HCl} 0,1 \mathrm{~mol} \mathrm{~L}^{-1}(\mathrm{HCl})$, Mehlich-3 (M-3) e DTPA.

13 Coeficiente de correlação linear simples entre a quantidade total de metal absorvida pelas plantas e os teores removidos do solo pelos vários extratores, considerando os tratamentos que receberam doses de lodo.

14 Produção de matéria seca da parte aérea das plantas, em função da adição de fósforo e potássio mineral.

15 Quantidade de enxofre $\left(\mathrm{SO}_{4}{ }^{-2}\right)$ acumulado nas plantas em função da adubação mineral fosfatada e potássica. 


\title{
ALTERAÇÕES NAS PROPRIEDADES QUÍMICAS DE UM ARGISSOLO ADUBADO COM LODO DE ESGOTO E DESENVOLVIMENTO E ACÚMULO DE NUTRIENTES EM PLANTAS DE MILHO
}

\author{
Autora: MARCIA APARECIDA SIMONETE \\ Orientador: Prof. Dr. JORGE DE CASTRO KIEHL
}

\section{RESUMO}

Este estudo teve o objetivo de (a) verificar os efeitos da aplicação de doses de lodo de esgoto sobre as propriedades químicas de um ARGISSOLO VERMELHO AMARELO, (b) avaliar o efeito da aplicação do resíduo, combinada ou não com adubação mineral contendo $\mathrm{P}, \mathrm{K}$ e $\mathrm{PK}$, no acúmulo de nutrientes e na produção de matéria seca da parte aérea de plantas de milho e (c) comparar extratores para avaliar a disponibilidade de metais pesados às plantas de milho. $\mathrm{O}$ experimento foi conduzido em casa-de-vegetação do Departamento de Solos e Nutrição de Plantas da ESALQ/USP, seguindo delineamento inteiramente casualizado. Amostras de $3 \mathrm{~kg}$ de terra da camada de $0-20 \mathrm{~cm}$ foram transferidas para vasos e tratadas com doses equivalentes a $0,10,20$, 30,40 e $50 \mathrm{Mg} \mathrm{ha}^{-1}$ (base seca) de lodo de esgoto e uma mistura de $\mathrm{CaCO}_{3}$ e $\mathrm{MgCO}_{3}$ p.a. (proporção 4 partes de $\mathrm{Ca}+1$ parte de $\mathrm{Mg}$ ) para elevar a saturação por bases a $70 \%$. Após 30 dias de incubação, retiraram-se amostras de cada vaso que foram analisadas quanto ao $\mathrm{pH}$ em $\mathrm{CaCl}_{2}, \mathrm{MO}, \mathrm{N}, \mathrm{P}, \mathrm{SO}_{4}, \mathrm{~K}, \mathrm{Ca}, \mathrm{Mg}, \mathrm{Na}, \mathrm{Al}, \mathrm{H}+\mathrm{Al}, \mathrm{SB}, \mathrm{CTC}$ a pH 7,0, V\% e $\mathrm{m} \%$. Também foram determinados os teores dos metais $\mathrm{Fe}, \mathrm{Mn}, \mathrm{Cu}, \mathrm{Zn}, \mathrm{Cd}, \mathrm{Ni}$, 
$\mathrm{Cr}$ e $\mathrm{Pb}$ extraídos por $\mathrm{HCl}$ 0,1 mol L ${ }^{-1}$, Mehlich-3 e DTPA a pH 7,3. Após incubação das amostras, realizou-se a aplicação de duas doses de fósforo mineral $\left(0\right.$ e $100 \mathrm{mg} \mathrm{kg}^{-1} \mathrm{de}$ P) e duas doses de potássio mineral ( 0 e $\left.100 \mathrm{mg} \mathrm{kg}^{-1}\right)$, resultando um fatorial de $6 \times 2 \times 2$ com 24 tratamentos e 4 repetições. Foram cultivadas cinco plantas de milho (Zea mays L.) por vaso durante 50 dias, após o que foi coletada a parte aérea (folhas + colmos) para a quantificação da produção de matéria seca e análises de $\mathrm{P}, \mathrm{K}, \mathrm{Ca}, \mathrm{Mg}, \mathrm{SO}_{4}, \mathrm{Fe}, \mathrm{Mn}$, $\mathrm{Zn}, \mathrm{Cu}, \mathrm{Cd}, \mathrm{Cr}, \mathrm{Ni}$ e $\mathrm{Pb}$. A aplicação de doses de lodo de esgoto elevou os teores de matéria orgânica e os valores de CTC e SB. Para o pH, constataram-se decréscimos de 0,4 unidade com a adição do resíduo, e conseqüente acréscimo nos teores de $\mathrm{Al}$ e $\mathrm{H}+\mathrm{Al}$ e no valor de $\mathrm{m} \%$. Os teores das formas disponíveis de $\mathrm{P}, \mathrm{SO}_{4}, \mathrm{Ca}, \mathrm{Mg}, \mathrm{Fe}, \mathrm{Mn}, \mathrm{Cu}$ e $\mathrm{Zn}$ no solo aumentaram com a aplicação do resíduo, resultando em aumento do acúmulo desses elementos pelas plantas. A produção de matéria seca da parte aérea das plantas aumentou com o aumento da dose do lodo. A complementação do resíduo com potássio mineral aumentou a produção de matéria seca da parte aérea das plantas, porém, a complementação com fósforo não alterou a produção de matéria seca. As soluções ácidas ( $\mathrm{HCl} \mathrm{0,01} \mathrm{mol} \mathrm{L}{ }^{-1}$ e Mehlich-3) apresentaram maior capacidade de extração de $\mathrm{Fe}, \mathrm{Cu}, \mathrm{Mn}$ e $\mathrm{Zn}$ em relação à solução de DTPA. Todas as três soluções extratoras foram eficientes para a predição da fitodisponibilidade de $\mathrm{Zn}$. Para o $\mathrm{Mn}$, os mais eficientes foram o $\mathrm{HCl} 0,01 \mathrm{~mol} \mathrm{~L}^{-1}$ e o Mehlich-3. Para os demais metais, há necessidade de se definir um extrator mais adequado. 


\title{
MODIFICATION OF CHEMICAL PROPERTIES OF AN ULTISOL FERTILIZED WITH SEWAGE SLUDGE AND DEVELOPMENT AND ACUMULATION OF NUTRIENTS IN MAISE PLANTS
}

\author{
Author: MARCIA APARECIDA SIMONETE \\ Adviser. Prof. Dr. JORGE DE CASTRO KIEHL
}

\section{SUMMARY}

This study aimed to (a) verify the effects of application of sewage sludge on chemical properties of an Red-Yellow Pozolic soil (Ultisol), (b) evaluate the effect of this residue application, combined or not with mineral fertilizer containing $\mathrm{P}, \mathrm{K}$ and $\mathrm{PK}$, on the nutrient accumulation and yield of dry matter of maize plant tops and (c) compare extractors for the evaluation of heavy metal availability to maize plants. The experiment was conducted in the greenhouse of the Soil Science \& Plant Nutrition Department of the ESALQ/USP, Brazil, following a completely randomized block design. Soil samples of $3 \mathrm{~kg}$, collected from the $0-20 \mathrm{~cm}$ soil layer were placed in pots and treated with 0,10 , 20, 30, 40 and $50 \mathrm{Mg} \mathrm{ha}^{-1}$ (dry-basis) sewage sludge and a mixture of $\mathrm{CaCO}_{3}$ and $\mathrm{MgCO}_{3}$ (4 parts of $\mathrm{Ca}+1$ part of $\mathrm{Mg}$ ) to increase base saturation to $70 \%$. Thirty days after incubation, samples were taken from each pot and analyzed for $\mathrm{pH} \mathrm{CaCl}_{2}$, organic matter, $\mathrm{N}, \mathrm{P}, \mathrm{SO}_{4}, \mathrm{~K}, \mathrm{Ca}, \mathrm{Mg}, \mathrm{Na}, \mathrm{Al}, \mathrm{H}+\mathrm{Al}, \mathrm{SB}, \mathrm{CEC}$ at $\mathrm{pH} \mathrm{7,} \mathrm{V \%} \mathrm{and} \mathrm{m} \%$. Contents of $\mathrm{Fe}, \mathrm{Mn}, \mathrm{Cu}, \mathrm{Zn}, \mathrm{Cd}, \mathrm{Ni}, \mathrm{Cr}$ and $\mathrm{Pb}$, extracted by $\mathrm{HCl} 0,1 \mathrm{~mol} \mathrm{~L}{ }^{-1}$, Mehlich-3 and DTPA of $\mathrm{pH} \mathrm{7,3} \mathrm{were} \mathrm{also} \mathrm{determined.} \mathrm{After} \mathrm{incubation,} \mathrm{two} \mathrm{doses} \mathrm{of} \mathrm{mineral}$ 
phosphate were applied $\left(0\right.$ and $\left.100 \mathrm{Mg} \mathrm{ha}^{-1} \mathrm{P}\right)$ as well as two doses of mineral potassium $\left(0\right.$ and $100 \mathrm{Mg} \mathrm{ha}^{-1} \mathrm{~K}$ ), resulting in a factorial $6 \times 2 \times 2$ arrangement with 24 treatments and 4 replicates. Five maize plants were grown in each pot for 50 days, after which the tops (leaves + stems) were collected, dryed, weighted and subjected to determination of $\mathrm{P}, \mathrm{K}, \mathrm{Ca}, \mathrm{Mg}, \mathrm{SO}_{4}, \mathrm{Fe}, \mathrm{Mn}, \mathrm{Zn}, \mathrm{Cu}, \mathrm{Cd}, \mathrm{Cr}, \mathrm{Ni}$ and $\mathrm{Pb}$. The application of sewage sludge increased the organic matter content as well as CEC and base saturation. Soil $\mathrm{pH}$ decreased 0,4 units after application of the residue, whereas the $\mathrm{Al}$ and $\mathrm{H}+\mathrm{Al}$ contents increased. Available forms of $\mathrm{P}, \mathrm{S}, \mathrm{Mn}, \mathrm{Cu}$ and $\mathrm{Zn}$ increased with the residue application, determining increases in the accumulation of these elements by plants. Dry matter yield also increased with residue application. The addition of mineral potassium to the residue increased the yield of dry matter, but the addition of mineral had no

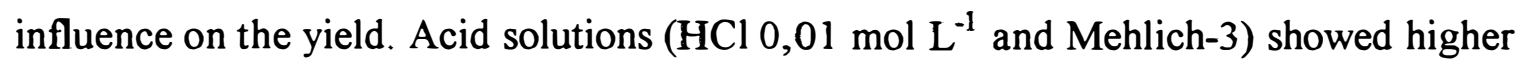
extraction capacity for $\mathrm{Fe}, \mathrm{Cu}, \mathrm{Mn}$ and $\mathrm{Zn}$ when compared to DTPA solution. All three solutions were efficient for prediction of $\mathrm{Zn}$ availability to plants. The $\mathrm{HCl} 0,1 \mathrm{~mol} \mathrm{~L}^{-1}$ and Mehlich-3 were the most efficient solutions for Mn. For the other metals, a more efficient extractor has to be found. 


\section{INTRODUÇÃO}

A falta de controle sobre a produção e destino final de resíduos gerados pela atividade humana e crescimento populacional, especialmente nos centros urbanos, vem se transformando num sério problema da atualidade. Dentre esses resíduos gerados, o esgoto merece destaque, não somente pelas grandes quantidades produzidas, mas também pelo seu potencial poluidor e formas de descartes inadequadas. Atualmente, a maior parte dos esgotos gerados no Brasil são lançados "in natura" em cursos d'água ou nos solos, ocasionando sérios problemas sanitários e ambientais através da ploriferação de vetores biológicos transmissores de doenças, liberação de gases tóxicos e contaminação de solo e dos mananciais hídricos.

Grandes centros urbanos têm promovido o tratamento de seus esgotos com objetivo de reduzir a carga orgânica e potencial poluidor dos mesmos, entretanto, no final do tratamento é gerado, em grande quantidade, outro resíduo denominado lodo de esgoto. Para se ter uma idéia da problemática do volume de esgoto gerado nas Estações de Tratamento de Esgotos (ETEs), somente na região metropolitana de São Paulo, o plano de uso e disposição de esgotos que envolve cinco ETEs preve para 2005 uma produção média diária de $565 \mathrm{Mg} \mathrm{kg}^{-1}$ de lodo.

Portanto, há necessidade de se encontrar um destino para esse volume de lodo, de maneira que respeite as normas de higiene pública, não polua o ambiente e seja economicamente viável, uma vez que o custo da disposição final do lodo de esgoto pode chegar até $56 \%$ das despesas operacionais das ETEs.

Dentre as op̧̧ões propostas para o destino final do lodo, a utilização em solos agrícolas tem se mostrado a alternativa de maior sustentabilidade. Pois, além de proporcionar uma forma de minimizar os problemas ambientais da disposição de 
grandes quantidades do resíduos gerados, pode viabilizar a reciclagem de nutrientes e promover melhorias nas propriedades químicas, fisicas e biológicas do solo, em função do seu conteúdo de matéria orgânica.

Efeitos benéficos da utilização de lodo de esgoto na agricultura têm sido demonstrados por alguns pesquisadores. No entanto, ainda permanecem muitas dúvidas sobre o efeito deste resíduo sobre os atributos do solo, bem como na capacidade de fornecimento de nutrientes às plantas e na fitodisponibilidade de metais.

Os lodos, dependendo da origem, podem apresentar em sua composição características que limitam a sua utilização agrícola. Dentre estas destaca-se: a presença de organismos patogênicos, material recalcitrante, altas concentrações de sais solúveis e, principalmente, metais pesados.

Recentemente, no Município de Piracicaba - SP foi inaugurada a ETE Piracicamirim que visa a despoluição das águas do Ribeirão Piracicamirim. Atualmente, a ETE trata o esgoto de 75 mil pessoas, gerando um volume diário de lodo de esgoto de $4 \mathrm{~m}^{3}$. Trata-se de um lodo tipicamente doméstico e com teor de metais pesados relativamente baixo que pode permitir o uso agronômico.

Diante do exposto, este trabalho propôs estudar, em casa-de-vegetação, os efeitos causados pela disposição de doses de lodo de esgoto proveniente da ETE Piracicamirim sobre as propriedades químicas de um ARGISSOLO VERMELHO AMARELO, avaliação de doses crescentes do resíduo combinadas ou não com adubação mineral de $\mathrm{P}, \mathrm{K}$ e PK na disponibilidade de nutrientes, produção de matéria seca em plantas de milho (Zea mays L) e estudo de extratores na fitodisponibilidade de metais. 


\section{REVISÃO DE LITERATURA}

\subsection{Caracterização do lodo de esgoto}

O lodo de esgoto é um resíduo semi-sólido proveniente do tratamento de esgotos, sejam eles domésticos, industriais ou agroindustriais. Trata-se de um resíduo predominantemente orgânico, com grandes atrativos para o uso agrícola, quer como condicionador do solo, quer como fonte de nutrientes para as plantas cultivadas, tendo em vista sua composição química que, dependendo da origem e do processo de produção, pode conter quantidades de nutrientes às vezes suficientes para atender às necessidades das plantas.

O lodo de esgoto, segundo Parr \& Willson (1980), contém aproximadamente 5\% de sólidos e $95 \%$ de água, sendo que esses valores variam de acordo com o tipo de lodo: 1 a $10 \%$ para o líquido, 20 a $30 \%$ para o semi-líquido e 25 a $80 \%$ para o sólido. 0 Departamento de Agricultura dos Estados Unidos - USDA (1980) caracteriza como lodo de esgoto típico o resíduo que contém cerca de $4 \%$ de nitrogênio, $2 \%$ de fósforo, $0,4 \%$ de potássio e $25 \%$ de carbono.

A caracterização química do lodo torna-se de fundamental importância, principalmente, quando se pretende utilizá-lo em solos agrícolas, fornecendo, assim, informações imprescindíveis como o estabelecimento de doses de aplicação e monitoramento dos efeitos no sistema solo-planta. No Brasil, ainda não foi realizada uma caracterização generalizada da composição química dos lodos gerados pelas ETEs. Entretanto, na Tabela 1 encontram-se as características químicas de alguns lodos utilizados em experimentos no Estado de São Paulo. 


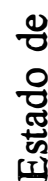

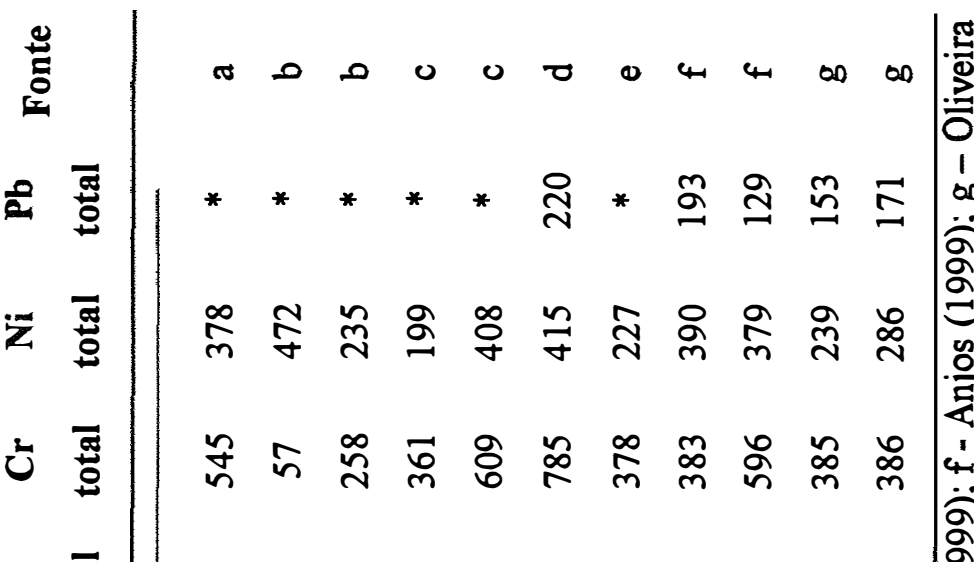
ర సี ह ⿷匚⿱

已

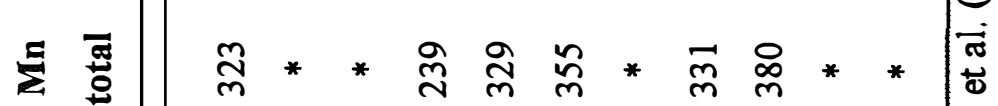

త్ర్ల

己

융

ఫ

융

ช্

:

$\approx$

营

畩 * *

8 \&

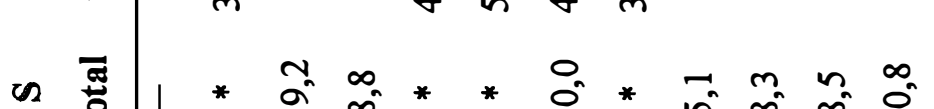

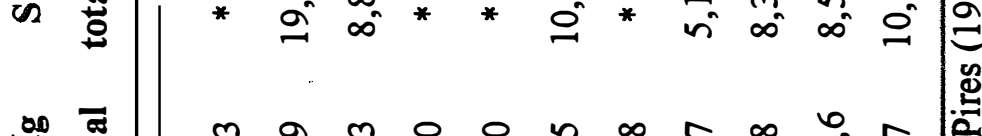

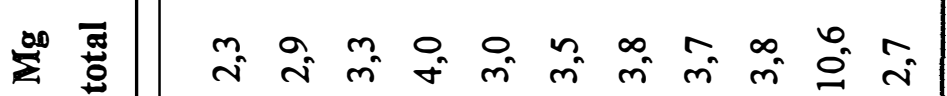

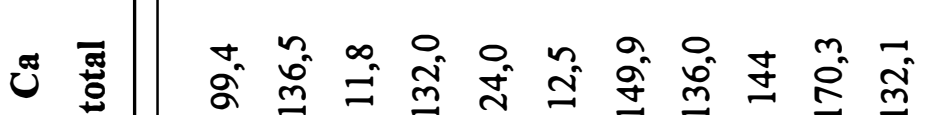

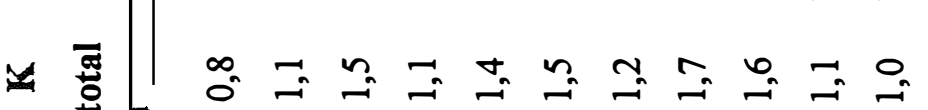

I.

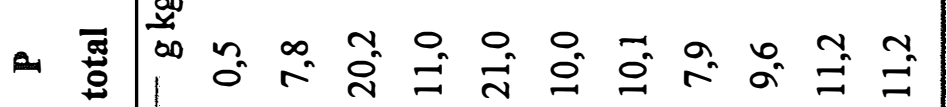

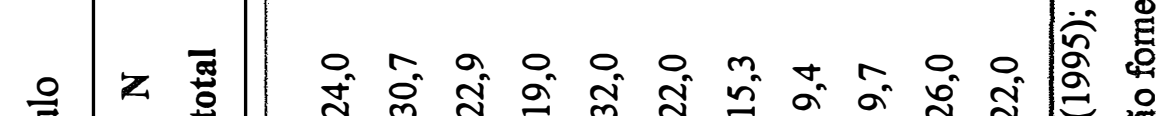

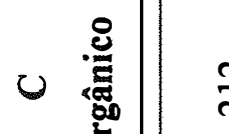

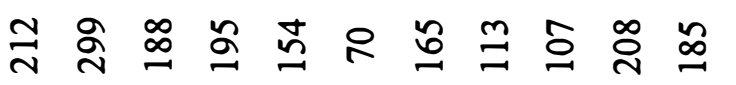

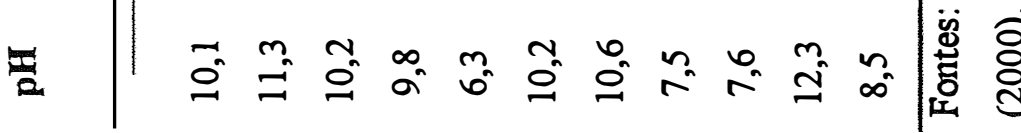


A Tabela 1 mostra que os lodos apresentam praticamente a mesma composição química, porém considerando os aspectos quantitativos, constata-se grande variabilidade. Esta variação é conseqüência da procedência do esgoto e do tipo de tratamento que o lodo recebe na ETE.

\subsection{Alterações nas propriedades químicas do solo com a adição de lodo de esgoto}

A matéria orgânica, embora represente menos de $5 \%$ dos componentes sólidos na maioria dos solos (Silva et al., 2000), é responsável por cerca de $30 \%$ a $65 \%$ da capacidade de troca cationica (CTC) dos solos minerais e mais de 50\% em solos arenosos e orgânicos (Shuman, 1977). Portanto, em solos de região de clima tropical e subtropical, onde a matéria orgânica desempenha papel fundamental na CTC, o emprego do lodo de esgoto se torna vantajoso pelo fato de ser fonte de matéria orgânica (Melo et al. 1994), melhorando as propriedades químicas pela elevação do pH (Silva, 1995; Bertoncini, 1997 e Oliveira, 2000), diminuição da acidez potencial (Dias, 1994), aumento gradual da disponibilidade de nitrogênio, fósforo, cálcio e magnésio (Ros, et al. 1993; Souza et al.,1998, Vaz, 2000) e também de micronutrientes (Korentajer, 1991 e Cantarella, et al., 1995).

Vários autores têm demonstrado alterações nas propriedades químicas do solo devido à aplicação do lodo de esgoto (Stark \& Clapp, 1980; Simione et al., 1984; Berton et al., 1989; Pietz et al., 1989; Dowdy et al., 1991; Melo et al., 1994; Silva, 1995; Logan et al.,1997; Silva et al., 1998; Oliveira, 2000).

Berton et al. (1989), trabalhando em condições de casa-de-vegetação com amostras de cinco solos paulistas acrescidos de doses equivalentes a 0,40 e $80 \mathrm{Mg} \mathrm{ha}^{-1}$ (base seca) de lodo, observaram que a ação inicial do lodo de esgoto foi elevar o pH dos cinco solos, reduzindo ou anulando os teores de Al. Constataram, também, incrementos nos teores de matéria orgânica e de $\mathrm{Ca}, \mathrm{Mg}, \mathrm{K}$ e $\mathrm{P}$ para todas as doses utilizadas, em ambos os solos estudados. De forma concordante, Silva et al. (1998) adicionaram doses de 0,15 e $30 \mathrm{Mg} \mathrm{ha}^{-1}$ (base seca) de lodo em solo Terra Roxa estruturada e concluiram 
que o lodo de esgoto teve ação corretiva parcial da acidez do solo, promovendo elevação do $\mathrm{pH}$ e aumentos nos teores de $\mathrm{P}, \mathrm{S} \mathrm{Ca}, \mathrm{Cu}, \mathrm{B}$ e $\mathrm{Zn}$.

Pietz et al. (1989) e Dowdy et al. (1991) verificaram que alguns lodos de esgoto podem acidificar o solo. Estes pesquisadores atribuíram a acidificação às reações de nitrificação do nitrogênio amoniacal, a provável oxidação de sulfitos e a produção de ácidos orgânicos durante a degradação do resíduo. Logan et al. (1997) observaram, em solo derivado de rochas calcárias, no primeiro ano de aplicação de lodo de esgoto (sem tratamento prévio com cal), um decréscimo no valor de $\mathrm{pH}$, para as menores doses de lodo (7,5 e $15 \mathrm{Mg} \mathrm{ha}^{-1}$ ), imediatamente após a aplicação do resíduo. Por outro lado, diversos trabalhos demonstram a capacidade do lodo de esgoto, sem tratamento prévio com cal, em elevar o pH dos solos (Stark \& Clapp, 1980). Nestes casos os autores atribuíram o efeito neutralizante às reações envolvidas na degradação da carga orgânica do resíduo.

Para a CTC, alguns trabalhos têm demostrado acréscimos em seus valores com a adição de lodo de esgoto (Simione et al., 1984; Melo et al., 1994; Silva, 1995). Todavia, diversas dúvidas ainda permanecem sobre a real contribuição do resíduo na capacidade de incrementar a CTC nos solos de região de clima tropical. Pois, tratam-se de solos com cargas, praticamente, dependentes de pH. Portanto, os incremento da CTC dos solos tratados com lodo pode estar associado a elevação do $\mathrm{pH}$.

Melo et al. (1994) verificaram que a aplicação de lodo na dose de $32 \mathrm{t} \mathrm{ha}^{-1}$ (com $32 \%$ de umidade) em Latossolo Vermelho Escuro distrófico promoveu aumento significativo na CTC e no teor de carbono orgânico do solo, avaliados até 473 dias após a aplicação do resíduo. De forma concordante, Silva (1995), aplicando doses de 0, 20 e $40 \mathrm{Mg} \mathrm{ha}^{-1}$ (com $62 \%$ de umidade) de lodo de esgoto em Podzólico Vermelho-Amarelo, observou aumentos na CTC do solo. Nestes trabalhos, além dos lodos utilizados terem sido ratados com cal, que pode realçar os efeitos na CTC pela elevação do $\mathrm{pH}$, a CTC foi calculada através da soma de bases, podendo estar sendo superestimada pelos altos teores de $\mathrm{Ca}$ adicionados via lodo de esgoto.

Simione et al. (1984), avaliaram o efeito da aplicação de $0,90,120$ e $240 \mathrm{Mg} \mathrm{ha}^{-1}$ (base seca) de lodo sobre o $\mathrm{pH}$ e CTC determinadas a pH 8,2, em amostras 
de um solo arenoso. Os resultados obtidos para o pH e CTC, para a testemunha e as doses de lodo, foram respectivamente os seguintes: pH: 5,1 , 5,0 , 5,0 e 4,7; CTC: 17,7, $19,5,21,3$ e 25,7 mmol $_{\mathrm{c}} \mathrm{kg}^{-1}$. Estes autores atribuíram o aumento da CTC ao aumento do carbono orgânico do solo. No entanto, observa-se que a CTC foi determinada a pH 8,2 , sendo assim os valores de CTC obtidos pelo autor não seriam reais e sim potenciais.

Dentre outras dificuldades relacionadas à disposição do lodo no solo está o fato de que a adição do resíduo tratado com cal poderá causar problemas relacionados com desbalanço de nutrientes no solo, principalmente com relação aos teores trocáveis de cálcio, magnésio e potássio. $\mathrm{O}$ excesso de cálcio em relação ao magnésio poderá dificultar a absorcão deste último pelas plantas, enquanto o excesso de magnésio em relação ao potássio poderá dificultar a absorção de potássio (Tisdale et al., 1985). Aliado a este fenômeno de antagonismo entre o cálcio, magnésio e potássio, o excesso de cálcio no solo promove maior ocupação deste nos sítios de trocas do solo, promovendo maior suscetibilidade de lixiviação de magnésio e potássio, agravando ainda mais o problema de desbalanço nutricional do solo. Efeitos do excesso de cálcio em solos tratados com lodo de esgoto, sobre a lixiviação de magnésio e potássio foram comprovados por Bertoncini (1997) e Anjos (1999).

\subsection{Lodo de esgoto como fertilizante}

O emprego do lodo de esgoto como fertilizante, nos países desenvolvidos, vem sendo prática usual para certas culturas. Nos Estados Unidos, por exemplo, esse produto tornou-se comercialmente disponível a partir de 1927 (Anderson, 1959).

Em relação às necessidades das culturas, Carvalho \& Barral (1981) afirmam que a decomposição do lodo de esgoto no solo permite melhor aproveitamento dos nutrientes pelas plantas, em decorrência da lenta liberação dos mesmos através do processo de mineralização da matéria orgânica.

Bunting (1963) relata que os níveis de nitrogênio e fósforo contidos no lodo de esgoto são adequados para suprir adequadamente as necessidades das plantas. De forma 
concordante, Linden et al. (1983) acrescentaram que a complementação com potássio deve ser considerada quando o potássio se encontra em baixa disponibilidade no resíduo. Giordano \& Mays (1981) salientam que o lodo de esgoto não é uma boa fonte de potássio para as plantas, e que os teores desse nutriente se encontram na faixa de 2 a $3 \mathrm{~g} \mathrm{~kg}^{-1}$. Bunting, (1963) relata que a concentração dos macronutrientes $\mathrm{K}, \mathrm{Ca}$ e $\mathrm{Mg}$ geralmente varia de acordo com a origem da água e os processos de tratamento do esgoto.

Para Ayuso et al. (1992), o lodo de esgoto constitui-se uma boa fonte de fósforo, o qual provém, em grande parte, de detergentes (polifosfatos). Esses mesmos autores concluíram que a incorporação de lodo de esgoto aos solos aumentou a quantidade de fósforo disponível e, conseqüentemente, a assimilação desse elemento pelas plantas. Sabey (1980) destaca que o fósforo está $70 \%$ na forma orgânica, possivelmente aproveitável no primeiro ano de cultivo.

Quanto ao nitrogênio, CAST (1980) relata que apenas $40 \%$ do $\mathrm{N}$ contido no lodo de esgoto se tornam disponíveis no primeiro ano após a aplicação, ou seja, culturas que respondem a elevadas taxas de nitrogênio, como o milho, o trigo e a batata, apresentam menores produtividades quando cultivadas em sistemas orgânicos do que quando cultivadas com fertilizantes minerais.

Alguns autores colocam como fator limitante, para o emprego do lodo como fertilizante, a presença de metais pesados. Para Galloway \& Jacobs (1977) os metais que aparecem no lodo são $\mathrm{Cd}, \mathrm{Cu}, \mathrm{Mo}, \mathrm{Zn}$, e $\mathrm{Pb}$, além de $\mathrm{Fe}, \mathrm{Mn}, \mathrm{Al}, \mathrm{Cr}$, e $\mathrm{Hg}$. Tais elementos podem causar fitotoxicidade em decorrência de manejo inadequado do $\mathrm{pH}$ do solo ou da aplicação acumulativa do metal via resíduo (Logan \& Chaney, 1983; Valadares et al., 1983).

\subsection{Resposta das culturas}

Efeitos benéficos da aplicação de lodo de esgoto sobre a absorção de nutrientes e produtividade das culturas têm sido comprovados por diversos autores (Berton et al., 
1989; Marques, 1990; Ros et al. 1993; Silva, 1995; Oliveira, 1995; Biscaia \& Miranda, 1996; Pereira Júnior et al., 1997; Silva et al., 1998; Souza et al., 1998; Anjos, 1999).

Berton et al. (1989) avaliaram, em casa-de-vegetação, a produção de matéria seca e a absorção de nutrientes por plantas de milho cultivadas em amostras de cinco solos paulistas tratadas com doses de 0, 40 e $80 \mathrm{Mg} \mathrm{ha}^{-1}$ (base seca) de lodo. Estes autores observaram que a adição do resíduo proporcionou aumentos na absorção de $\mathrm{N}, \mathrm{P}, \mathrm{Ca}$, $\mathrm{Mg}$ e Zn e na produção de matéria seca das plantas.

Em estudo realizado em campo, Marques (1990) comparou os efeitos da fertilização mineral em relação à aplicação de doses crescentes de lodo de esgoto $(4,8$, 16 e $32 \mathrm{Mg} \mathrm{ha}^{-1}$ com $77 \%$ de umidade), complementado com potássio, sobre a produtividade e qualidade industrial da cana-de-açúcar. $\mathrm{O}$ autor concluiu que é possível a utilização do resíduo na cultura, uma vez que a produtividade e a qualidade da cana, em todos os tratamentos, não apresentaram diferenças significativas em relação a fertilização mineral.

Avaliando o efeito imediato da aplicação de doses de 0,20,40,80 e $160 \mathrm{Mg} \mathrm{ha}^{-1}$ (base seca) de lodo sobre o rendimento da matéria seca da cultura do milheto e efeito residual sobre a associação das culturas aveia-ervilhaca cultivadas em solo Podzólico Vermelho-Amarelo, em condições de campo, Ros et al. (1993) constataram aumentos significativos no rendimento da matéria seca do milheto (efeito imediato) e da associação aveia-ervilhaca (efeito residual). Observaram também que, pelo efeito residual, o lodo aplicado proporcionou incrementos no rendimento de grãos de aveia.

Aplicando doses de 0, 20 e $40 \mathrm{Mg} \mathrm{ha}^{-1}$ (com 62\% de umidade) de lodo de esgoto, combinadas com adubação mineral NP, NK, PK e NPK em Podzólico VermelhoAmarelo cultivado com cana-de-açúcar, Silva (1995) verificou que o lodo de esgoto atuou como fonte de $\mathrm{P}, \mathrm{Ca}, \mathrm{S}$ e $\mathrm{Zn}$ para a cultura, proporcionando aumentos lineares da produtividade de açúcar. Entretanto, observou que nos tratamentos onde foram aplicados o resíduo sem complementação de $\mathrm{N}$ mineral, houve deficiência deste nutriente para as plantas. $\mathrm{O}$ autor associou este fato à possível imobilização do $\mathrm{N}$ nativo do solo, durante a fase inicial de decomposição da parte orgânica do lodo recém adicionado. 
Oliveira et al. (1995), trabalhando em condições de casa-de-vegetação, compararam os efeitos da adição de doses de lodo $\left(0,5,10\right.$ e $20 \mathrm{Mg}^{-1}$ na base seca), complementadas ou não com $\mathrm{N}$ e/ou $\mathrm{K}$, sobre a absorção de nutrientes e produção de matéria seca por plantas de sorgo granífero cultivadas em Latossolo Vermelho Escuro. Estes autores constataram que a incorporação do resíduo no solo aumentou a absorção de N, P, S, Ca e Mg pelas plantas, promovendo aumentos na produção de matéria seca. Todavia, observaram que nos tratamentos sem complementação mineral de $\mathrm{K}$, as plantas apresentaram sintomas visuais de deficiência deste elemento. Sendo assim, concluíram que, para atender as necessidades da cultura, fez-se necessário a complementação do lodo com potássio mineral.

Em estudo de campo conduzido num Cambissolo de média fertilidade, com patamar razoável de produtividade para a cultura do milho $\left(5 \mathrm{Mg} \mathrm{ha}^{-1}\right)$, que recebeu 60 $\mathrm{Mg} \mathrm{ha}^{-1}$ (base seca) de lodo de esgoto, Biscaia \& Miranda (1996) constataram que esse resíduo proporcionou um incremento médio de $2,62 \mathrm{Mg} \mathrm{ha}^{-1}$ na produtividade da cultura do milho.

Pereira Junior et al. (1997), avaliando a eficiência do lodo de esgoto na produtividade da cultura do milho, cultivado em Latossolo Vermelho-amarelo tratado com 3, 6, 12 e $15 \mathrm{Mg} \mathrm{ha}^{-1}$ de lodo (com 30\% de umidade), em condições de campo, observaram aumentos na produtividade do milho de $14 \%, 15 \%, 32 \%$ e $35 \%$, para as respectivas doses. Os autores indicaram que o uso desse resíduo pode contribuir para elevar a produtividade média desta cultura no Brasil.

Em experimento de campo, Silva et al. (1998) avaliou o lodo de esgoto como fonte de nutrientes para a cultura da cana-de-açúcar cultivada em solo Podzólico Vermelho-Amarelo, utilizando-se doses de 0,15 e $30 \mathrm{Mg} \mathrm{ha}^{-1}$ (com 65\% de umidade) combinadas com adubo mineral NP, NK, PK, NPK e sem adubo. Observaram que a aplicação do lodo causou aumentos na absorção de $\mathrm{P}, \mathrm{S}, \mathrm{Ca}, \mathrm{Cu}$ e $\mathrm{Mg}$ pela parte aérea das plantas, promovendo aumento na produtividade de açúcar da cultura.

Souza et al. (1998), trabalhando com Latossolo Roxo (LR) e Latossolo Vermelho Escuro (LE) tratados com $0 ; 2,49 ; 4,97$ e $9,94 \mathrm{Mg} \mathrm{ha}^{-1}$ de lodo de esgoto e cultivados milho, em condições de campo, observaram que somente no LR ocorreu diferenças 
significativas entre a produção de matéria seca da testemunha e do tratamento que recebeu a maior dose de lodo. No entanto, para o rendimento de grãos, verificou-se maior produção no LE, nos tratamentos que receberam lodo.

Anjos (1999), cultivando plantas de milho em Latossolo Roxo distrófico e Latossolo Vermelho Escuro, nos quais foram realizadas cinco aplicações de lodo que totalizaram $387,89 \mathrm{Mg} \mathrm{ha}^{-1}$ (base seca), verificou que a aplicação do resíduo promoveu aumento na produção de matéria seca das plantas; entretanto, não houve aumento de produtividade quando comparada com tratamentos que receberam somente adubação mineral. Observou também que, apesar dos teores de $\mathrm{P}$ e $\mathrm{N}$ nos solos terem sido aumentados com as incorporações do resíduo, as plantas apresentaram sintomas visuais de deficiências destes elementos para ambos os solos, o que foi corrigido com adubação mineral.

\subsection{Metais Pesados}

O termo metal pesado tem sido utilizado de forma bastante abrangente para designar qualquer elemento (metal, semi-metal e não metal) que esteja associado a problemas de poluição, contaminação e toxicicidade no solo. Entretanto, a rigor, este termo defini elementos químicos que apresentam densidade maior que $5 \mathrm{~g} \mathrm{~cm}^{-3}$ (Mattiazzo-Prezotto, 1992; Melo et al., 1997).

A presença de metais pesados em concentrações relativamente elevadas no lodo de esgoto tem constituído um dos maiores entraves na utilização deste resíduo em solos agrícolas. Aplicações sucessivas de lodo podem levar ao acúmulo destes elementos no solo e, consequentemente, sua transferência para a cadeia alimentar através de plantas e animais ou contaminação de recurso hídricos.

Em geral, os metais encontrados no lodo de esgoto são: $\mathrm{Cd}, \mathrm{Cr}, \mathrm{Ni}, \mathrm{Pb}, \mathrm{Fe}, \mathrm{Co}$, Mn, Mo, Hg, Sn e Zn (Berton, 2000). Entre estes, deve-se considerar que alguns são essenciais às plantas ( $\mathrm{Cu}, \mathrm{Fe}, \mathrm{Mn}, \mathrm{Mo}, \mathrm{Ni}$ e $\mathrm{Zn}$ ) (Malavolta, 1994). Segundo Fuller \& Warrick (1985), o lodo de esgoto proveniente de tratamento de esgoto doméstico, com 
predominância sobre os industriais, apresenta teores de metais dentro das faixas permitidas para o seu uso agronômico. CAST (1976) relata que, dentre os metais que podem ocorrer no lodo, o $\mathrm{Cd}, \mathrm{Cu}, \mathrm{Ni}, \mathrm{Zn}$ e $\mathrm{Mo}$ são os de maior potencial para acumular em plantas.

\subsubsection{Acúmulo de metais no solo e nas plantas}

O solo possui grande capacidade de retenção de metais pesados; porém, se essa capacidade for ultrapassada, os metais em disponibilidade no meio tanto podem entrar na cadeia alimentar dos organismos vivos como serem lixiviados, colocando em risco a qualidade dos sistemas subjacentes de água subterrânea (Bittell \& Miller, 1974; Elliot et al., 1986).

Kim et al. (1988) ressaltam que a introdução de metais pesados na cadeia alimentar não depende somente das características do lodo e das doses aplicadas, mas também das características químicas e mineralógicas dos solos nos quais o resíduo é aplicado, das características climáticas da região e das espécies de plantas cultivadas.

Diversos trabalhos têm demostrado que a aplicação de lodo de esgoto promove o aumento da concentração de metais no solo (Galloway \& Jacobs, 1977; Chang et al., 1987; Sommers et al., 1987; Korentajer, 1991; Barreto, 1995; Marques, 1996). No entanto, devido ao comportamento desses elementos no solo, ainda existem dúvidas no que diz respeito à absorção dos metais pesados pelas plantas e à possibilidade desses elementos alcançarem concentrações fitotóxicas nos solos ou nas plantas.

Em amplo estudo sobre a absorção de metais pesados por plantas cultivadas em solos que receberam doses anuais de lodo, por aproximadamente 10 anos, Chang et al. (1987) constataram que a absorção de metais pelas plantas, de maneira geral, é inferior a $1 \%$ da quantidade adicionada via lodo de esgoto.

Bidwill \& Dowdy (1987), avaliando a disponibilidade de $\mathrm{Cr}, \mathrm{Cu}, \mathrm{Ni}$ e $\mathrm{Pb}$ para a cultura do milho em um solo franco siltoso tratado anualmente com três aplicações de lodo, que totalizaram 0, 60 e $120 \mathrm{Mg} \mathrm{ha}^{-1}$ (base seca), por um período de seis anos, constataram que a adição do resíduo promoveu maior acúmulo de $\mathrm{Cd}$ e $\mathrm{Zn}$ nos colmos 
das plantas. Dos metais analisados, somente o Cd presente nos colmos excedeu o nível de $0,5 \mathrm{mg} \mathrm{kg}^{-1}$ (máximo estabelecido pela National Research Council para a alimentação animal) em todos os tratamento com lodo, desde o primeiro ano de aplicação. Para as concentrações de $\mathrm{Cr}, \mathrm{Cu}, \mathrm{Ni}$ e $\mathrm{Pb}$ encontrados nos colmos e grãos, os autores não atribuíram às adições do resíduo, uma vez que apresentaram oscilações anuais.

Em estudo conduzido por Rappaport et al. (1988), em três solos de texturas distintas (areia franca, franco argiloso e franco siltoso) que receberam doses de $0,42,84$, 126 e $168 \mathrm{Mg} \mathrm{ha}^{-1}$ (base seca) de lodo, observaram que, apesar das aplicações de $\mathrm{Cu}$ e $\mathrm{Zn}$ via lodo de esgoto excederem os limites estabelecidos pela Agência de Proteção Ambiental dos Estados Unidos, não houve fitotoxicidade destes elementos às plantas de milho, nos três solos estudados.

Oliveira (1995), trabalhando em condições de casa de vegetação com solos Areia Quartzosa e Latossolo Roxo, cujos níveis de pH foram ajustados para 3,9 e 4,9, e posteriormente foram tratados com $0 ; 13,5 ; 29,7$ e $40,5 \mathrm{Mg} \mathrm{ha}^{-1}$ (base seca) de lodo de esgoto e cultivado com plantas de milho, observou que, embora as aplicações do resíduo tenham promovido aumentos nas concentrações do metais $\mathrm{Cd}, \mathrm{Cu}, \mathrm{Cr}$, $\mathrm{Ni}$ e $\mathrm{Zn}$ nos dois solos, a fitodisponibilidade para as plantas só foi verificada para a maior dose de lodo empregada.

Ao avaliar a capacidade do acúmulo de metais no solo e nas plantas de milho cultivadas em Latossolo Roxo distrófico de textura argilosa e Latossolo VermelhoAmarelo distrófico de textura média, os quais receberam cinco aplicações de lodo de esgoto que totalizaram 387,89 $\mathrm{Mg} \mathrm{ha}^{-1}$ (base seca), Anjos e Mattiazzo (2000) verificaram, para os dois solos tratados com lodo, aumentos nas concentrações de $\mathrm{Cd}$, $\mathrm{Cr}, \mathrm{Cu}, \mathrm{Ni}$ e $\mathrm{Zn}$; entretanto, estas elevações não ultrapassaram os limites estabelecidos pela Agência de Proteção Ambiental do Estados Unidos e pela Diretriz da Comunidade Européia. Para o $\mathrm{Pb}$, o teor mostrou-se abaixo do limite de determinação pelo método utilizado. Os autores salientam que as quantidades removidas, em geral, estiveram abaixo das quantidades adicionadas via lodo de esgoto. Quanto ao acúmulo de metais pelas plantas, constatou-se aumentos de $\mathrm{Cu}$ e $\mathrm{Zn}$ nas diversas partes das plantas analisadas, porém não foram constatados problemas de fitotoxicidade. $\mathrm{Os}$ metais $\mathrm{Cd}, \mathrm{Cr}$, 
$\mathrm{Ni} \mathrm{e} \mathrm{Pb}$, de maneira geral, apresentaram-se abaixo do limite de determinação do método analítico utilizado.

Trabalhando em condições de campo com Latossolo Vermelho-Amarelo cultivado com cana-de-açúcar, Oliveira (2000) avaliou os efeitos causados pela disposição de lodo, por dois anos consecutivos, em doses de 33, 66, $99 \mathrm{Mg} \mathrm{ha}^{-1}$ (base seca, no primeiro ano) e $37,74,110 \mathrm{Mg} \mathrm{ha}^{-11}$ (base seca, no segundo ano) sobre o aumento dos teores de metais pesados no solo e na cultura. $\mathrm{O}$ autor constatou que no final do segundo ano foram detectados acúmulos de $\mathrm{Cu}, \mathrm{Cr}$, Ni e $\mathrm{Zn}$ na camada de 0-20 $\mathrm{cm}$ do solo, enquanto o $\mathrm{Cd}$ e $\mathrm{Pb}$ não foram detectados pelo método analítico empregado no estudo. Nas plantas, foi observado que, apesar da grande quantidade de lodo adicionado, os teores de $\mathrm{Cd}, \mathrm{Cr}, \mathrm{Ni}$ e $\mathrm{Pb}$ absorvidos pela cultura estiveram abaixo dos limites de determinação do método empregado.

\subsubsection{Avaliação da fitodisponibilidade de metais}

A contaminação causada por metais pesados nos solos tratados com lodo de esgoto tem sido avaliada pela concentração total desses metais no solo. No entanto, o fato do metal pesado estar presente no solo não significa que esteja numa forma prontamente assimilável pelas plantas, podendo permanecer por longos períodos sem ser absorvido em quantidades tóxicas. De acordo com Egreja Filho (1993), estudos têm demonstrado não haver correlação entre o teor total de metais pesados no solo e sua fitotoxicidade. Portanto, para se conhecer a contaminação em termos dos efeitos sobre as plantas e a cadeia alimentar, é necessário determinar as concentrações fitodisponíveis desses metais (Leschber et al., 1985).

$\mathrm{O}$ procedimento comumente utilizado para a avaliação da fitodisponibilidade de metais consiste em extraí-los do solo com uma solução química e correlacionar as concentrações obtidas no solo com a quantidade determinada nas plantas (Adriano, 1986). A eficiência do extrator é dada pelo grau de correlação entre estas duas determinações.

Vários métodos têm sido estudados para predizer as quantidades disponíveis dos 
metais pesados, a fim de determinar se um elemento encontra-se em concentração tóxica no solo. Entre os extratores encontrados na literatura, para estudar a fitodisponibilidade em áreas que recebem lodo de esgoto, pode-se destacar o ligante orgânico ou complexante DTPA e as soluções ácidas $\mathrm{HCl} 0,1 \mathrm{~mol} \mathrm{~L}^{-1}$ e Mehlich-3 (Roca \& Pomares, 1991; Singh et al., 1994; Bertoncini, 1997; Anjos, 1999; Oliveira, 2000).

$\mathrm{O}$ uso de agentes complexante decorre da sua habilidade de deslocar metais ligados a radicais orgânicos e carbonatos (McGrath \& Cegarra, 1992), extraindo com facilidade as formas lábeis dos metais, sem dissolver as não lábeis (Abreu et al., 1997). O extrator DTPA a pH 7,3, proposto por Lindsay \& Norvell (1978), para determinação de $\mathrm{Cu}, \mathrm{Zn}, \mathrm{Fe}$ e $\mathrm{Mn}$ em solos calcários e em solos com valores de pH próximos à neutralidade. Atualmente, os laboratórios de análise de solo do Estado de São Paulo têm utilizado esse extrator como método oficial para determinação de $\mathrm{Fe}, \mathrm{Cu}, \mathrm{Mn}$ e $\mathrm{Zn}$ (Cantarella et al., 1995). Em diversos trabalhos esta solução também tem sido utilizada para determinar outros metais como Cd, Ni e Pb em solos (Street et al., 1977; King \& Hajjar, 1990; Mulchi et al.1991; Keller \& Védy, 1994; Abreu et al., 1995; Oliveira, 2000).

$\mathrm{O}$ extrator ácido $\mathrm{HCl} 0,1 \mathrm{~mol} \mathrm{~L}^{-1}$ extrai quantidades próximas do total devido ao seu potencial em dissolver, mesmo que parcialmente, as estruturas que retêm metais pesados no solo Apesar disso, muitas vezes as quantidades extraídas correlacionam-se com as absorvidas pelas plantas (Taylor et al., 1993; Roca \& Pomares, 1991).

Recentemente, o extrator Mehlich-3 foi introduzido para o uso em solos ácidos e tem despertado crescente interesse por pesquisadores, pois dentre os métodos de extração ácida, foi considerado o mais apropriado e o mais econômico para a análise de terra em laboratório devido à sua capacidade de extrair do solo, simultaneamente, vários nutrientes ( $\mathrm{P}, \mathrm{K}, \mathrm{Ca}, \mathrm{Mg}, \mathrm{Na}, \mathrm{B}, \mathrm{Cu}, \mathrm{Fe}, \mathrm{Mg}$ e $\mathrm{Zn}$ ) (Tran et al., 1990). Este método foi adaptado a partir do extrator Mehlich-2 pela associação do princípio da quelação (EDTA), com a acidez para melhorar a eficiência de extração dos micronutrientes. A adição de EDTA aumentou as extrações de Cu em $170 \%$, a de $\mathrm{Mn}$ em $50 \%$ e a de $\mathrm{Zn}$ em 25\% (Mehlich, 1984). As vantagens do uso de Mehlich-3 para análise de terra em laboratório, seriam de permitir a determinação simultânea de vários nutrientes e o menor 
tempo de agitação requerido ( $5 \mathrm{~min}$ ), quando comparado com o método DTPA a pH 7,3 ( 2 horas).

Em estudo conduzido em casa de vegetação, com amostras de um solo Podzólico de textura média com três níveis de $\mathrm{pH}(5,2 ; 5,8 ; 6,4)$ que receberam durante três anos doses de $0,9,18$, e $27 \mathrm{Mg} \mathrm{ha}^{-1}$ de lodo de esgoto na forma líquida, King \& Hajjar (1990) avaliaram o efeito residual do lodo sobre a disponibilidade de metais para plantas de amendoim e fumo. Os resultados de correlações múltiplas, considerando os níveis de $\mathrm{pH}$ do solo, revelaram que o extrator DTPA foi melhor que o Mehlich-3 para predizer a fitodisponibilidade de $\mathrm{Cd}, \mathrm{Cu}, \mathrm{Ni}$ e $\mathrm{Zn}$. Para o $\mathrm{Cr}$ e $\mathrm{Pb}$, devido aos baixos teores desses elementos apresentados pela planta, não foi possível obter resultados conclusivos.

Mulchi et al. (1991) estudaram o efeito residual da aplicação de lodo de esgoto sobre a disponibilidade de metais para a cultura do fumo em solos franco siltoso e franco arenoso, que receberam durante oito anos doses de 0,56, 112 e $224 \mathrm{Mg} \mathrm{ha}^{-1}$ (base seca) daquele resíduo. Os autores verificaram que os extratores Mehlich-1, Mehlich-3 e DTPA foram eficientes na predição da fitodisponibilidade de $\mathrm{Cd}, \mathrm{Cu}, \mathrm{Ni}$ e $\mathrm{Zn}$; e para o $\mathrm{Mn}$ o melhor extrator foi o Mehlich-1. Nenhum extrator se mostrou eficiente enquanto para $o$ $\mathrm{Fe}$ e o $\mathrm{Pb}$.

Em experimento de campo conduzido em solo calcário tratado com doses de lodo equivalentes a 400, 800 e $1200 \mathrm{Mg} \mathrm{ha}^{-1}$ ano $^{-1}$, onde realizam cultivos seqüenciais de batata-milho (primeiro ano), batata-alface (segundo ano) e batata (terceiro ano), Roca \& Pomares (1991) verificaram que a eficiência dos extratores utilizados (água régia, $\mathrm{HCl}$ $0,1 \mathrm{~mol} \mathrm{~L}^{-1}$ e DTPA) para predizer a fitodisponibilidade de metais foi influenciada pelas diferentes espécies vegetais cultivadas. Para as plantas de batata foram encontradas correlações estreitas para $\mathrm{Zn}, \mathrm{Cu}$ e $\mathrm{Ni}$ extraídos por DTPA e água régia, e para $\mathrm{Zn}$ e Ni extraídos por $\mathrm{HCl} 0,1 \mathrm{~mol} \mathrm{L^{-1 }}$. Nenhum dos extratores apresentou correlações significativas para os teores dos metais presentes nas folhas do milho, porém, para os grãos foram obtidas correlações para $\mathrm{Cd}$ extraído por $\mathrm{HCl} 0,1 \mathrm{~mol} \mathrm{~L}^{-1}$ e $\mathrm{Pb}$ extraído por DTPA e água régia. Quanto à cultura da alface, foram obtidas correlações para $\mathrm{Zn}$ e $\mathrm{Cd}$ extraídos por DTPA e água régia, e para $\mathrm{Cd}$ e $\mathrm{Ni}$ extraídos por $\mathrm{HCl} 0,1 \mathrm{~mol} \mathrm{~L}^{-1}$.

Abreu et al. (1995) estudaram a eficiência dos extratores Mehlich-1, Mehlich-3 e 
DTPA na avaliação da disponibilidade de metais em 31 amostras de solos representativos do Estado de São Paulo. Verificaram que o extrator Mehlich-3 apresentou maior capacidade de extração de $\mathrm{Cd}, \mathrm{Cr}, \mathrm{Ni}$ e $\mathrm{Zn}$, seguido do Mehlich-1 e DTPA Quanto à fitodisponibilidade, constataram que todos os extratores se mostraram ineficientes na predição da disponibilidade de $\mathrm{Cd}, \mathrm{Cr}, \mathrm{Ni}$ e $\mathrm{Pb}$ para plantas de trigo e de $\mathrm{Pb}$ e $\mathrm{Cd}$ para plantas de feijão. Os autores atribuíram a ineficiência dos extratores ao baixo teor dos metais presentes no solo. O Mehlich-1 e o Mehlich-3 foram eficientes na predição da disponibilidade do $\mathrm{Cr}$ para as plantas de feijão, enquanto o Mehlich-3 e o DTPA, foram os mais eficientes para o Ni.

Bertoncini (1997), avaliando diversos extratores para a determinação de teores solúveis de $\mathrm{Cd}, \mathrm{Cr}, \mathrm{Cu}, \mathrm{Ni}$ e $\mathrm{Zn}$ em Latossolo Vermelho-Amarelo (LV), Latossolo Vermelho Escuro (LE) e Areia Quartzosa (AQ) tratados com sucessivas aplicações de lodo, totalizando $156 \mathrm{Mg} \mathrm{ha}^{-1}$ (base seca), verificou que a solução $\mathrm{HCl} 0,1 \mathrm{~mol} \mathrm{~L}^{-1}$ se mostrou mais eficiente na extração dos teores solúveis dos metais do que as soluções Mehlich-3 e DTPA, exceto para o Cu no LV+lodo (Mehlich-3 foi melhor extrator) e LE+lodo (DTPA não diferiu de $\mathrm{HCl} 0,1 \mathrm{~mol} \mathrm{~L}^{-1}$ ).

Avaliando a eficiência dos extratores $\mathrm{HCl} 0,1 \mathrm{~mol} \mathrm{~L}^{-1}$, Mehlich-3 e DTPA na fitodisponibilidade de metais para plantas de milho cultivadas em Latossolo Vermelho Escuro e Latossolo Roxo distrófico que receberam doses sucessivas de lodo, totalizando $387,89 \mathrm{Mg} \mathrm{ha}^{-1}$ (base seca), Anjos (1999) constatou que o extrator Mehlich-3 foi o mais eficiente na avaliação da disponibilidade de $\mathrm{Cu}$ e $\mathrm{Zn}$ para as plantas, enquanto que para o $\mathrm{Cd}, \mathrm{Ni}, \mathrm{Pb}$ e $\mathrm{Cr}$, nenhum extrator se mostrou adequado.

Oliveira (2000), trabalhando em Latossolo Vermelho Escuto tratado com lodo de esgoto nas doses de 33, 66 e $99 \mathrm{Mg} \mathrm{ha}^{-1}$ (base seca) no primeiro ano e 37, 74 e $110 \mathrm{Mg}$ $\mathrm{ha}^{-1}$ (base seca) no segundo ano, e cultivado com cana-de-açúcar, observou que os extratores $\mathrm{HCl}$ 0,1 mol L ${ }^{-1}$, DTPA e Mehlich-3 foram eficientes apenas na avaliação da fitodisponibilidade de $\mathrm{Zn}$, quando considerado apenas os tratamentos que receberam doses de lodo.

Nota-se pelos trabalhos aqui comentados que não existe um único extrator que se correlacione adequadamente para todos os metais e que seja eficiente para predizer a 
fitodisponibilidade desses elementos, tendo em vista a influência de variáveis como tipo de metal, solo, clima e cultura, aliadas ao fato de que em solos onde são adicionados metais via lodo de esgoto, estudos têm demostrado que, na maioria dos casos, a absorção pelas plantas não se correlaciona linearmente com a quantidade de metais adicionadas no solo.

\subsubsection{Aspectos de legislação}

Os países desenvolvidos, onde a utilização de lodo de esgoto como fertilizante é tida como prática usual, apresentam legislações bem definidas para a disposição desse resíduo em áreas agrícolas. Nos Estados Unidos a Environmental Protection Agency (USEPA, 1995) determina as quantidades máximas de metais pesados que podem estar presentes no lodo, bem como a quantidade máxima de metais que podem ser adicionadas ao solo em função dos teores de metais presentes no resíduo (Tabela 2).

No Brasil, onde o estudo científico do efeito da adição de lodo em solos agrícolas está em fase inicial, ainda não se tem regulamentações quanto ao uso agrícola do lodo. Alguns estados, como São Paulo e Paraná, apresentam propostas para regulamentar a utilização deste resíduo em áreas agrícolas, tendo como base as normas elaboradas pelos EUA e Comunidade Européia, respectivamente. No entanto, é preciso atentar para os riscos envolvidos na adoção de critérios estabelecidos nesses países devido às diferenças nas condições de clima e solo. Torna-se então necessário desenvolver estudos que tragam maior número de informações sobre as reais condições do uso deste resíduo em solos de regiões de clima tropical. 
Tabela 2. Limites de metais pesados estabelecidos pela EPA para a utilização de lodo de esgoto em solos agrícolas

\begin{tabular}{cccc}
\hline Elemento & $\begin{array}{c}\text { Concentração máxima } \\
\text { no lodo }\end{array}$ & $\begin{array}{c}\text { Dose máxima de aplicação } \\
\text { anual }\end{array}$ & $\begin{array}{c}\text { Taxa máxima de } \\
\text { aplicação acumulada }\end{array}$ \\
\hline Arsênio & $\mathrm{mg} \mathrm{kg}^{-1}$ & $\mathrm{~kg} \mathrm{ha}^{-1} \mathbf{a n o}^{-1}$ & $\mathbf{k g ~ h a ~}^{-1}$ \\
Cádmio & 75 & 2 & 41 \\
Cobre & 85 & 2 & 39 \\
Chumbo & 4300 & 75 & 1500 \\
Mercúrio & 840 & 15 & 300 \\
Molibdênio & 57 & 0,85 & 17 \\
Níquel & 75 & - & - \\
Selênio & 420 & 21 & 420 \\
Zinco & 100 & 5 & 100 \\
\hline Adaptado da & 7500 & 140 & 2800 \\
\hline
\end{tabular}

Adaptado da U. S. Environmental Protection Agency Office of Waswater Management - EPA Part 503 (USEPA, 1995). 


\section{MATERIAL E MÉTODOS}

O presente trabalho foi desenvolvido em duas fases, ambas em condições de casa-de-vegetação, junto ao Departamento de Solos e Nutrição de Plantas da Escola Superior de Agricultura "Luiz de Queiroz", ESALQ/USP em Piracicaba - SP. A primeira fase teve por objetivo o estudo dos efeitos da aplicação de doses de lodo de esgoto sobre as propriedades químicas do solo. A segunda fase teve por objetivo avaliar o efeito de doses crescentes do resíduo, combinadas ou não com adubação mineral de $\mathrm{P}$, $\mathrm{K}$ e PK, na disponibilidade de elementos e produção de matéria seca em plantas de milho.

\subsection{Solo}

O solo utilizado no experimento, coletado da camada $0-20 \mathrm{~cm}$, foi o ARGISSOLO VERMELHO AMARELO situado na Fazenda Areão, no Município de Piracicaba/SP. Apresentou $\mathrm{pH}$ em $\mathrm{CaCl}_{2} 0,01 \mathrm{~mol} \mathrm{~L}^{-1}=4,5, \mathrm{MO}=17 \mathrm{~g} \mathrm{dm}^{-3}, \mathrm{P}=13 \mathrm{mg}$ $\mathrm{dm}^{-3}, \mathrm{~S}^{-\mathrm{SO}_{4}}=32 \mathrm{mg} \mathrm{dm}^{-3}, \mathrm{~K}=1,8 \mathrm{mmol}_{\mathrm{c}} \mathrm{dm}^{-3}, \mathrm{Ca}=36 \mathrm{mmol}_{\mathrm{c}} \mathrm{dm}^{-3}, \mathrm{Mg}=20 \mathrm{mmol}_{\mathrm{c}} \mathrm{dm}^{-3}$, $\mathrm{Al}=3 \mathrm{mmol}_{\mathrm{c}} \mathrm{dm}^{-3}, \mathrm{H}+\mathrm{Al}=42 \mathrm{mmol}_{\mathrm{c}}, \mathrm{SB}=58 \mathrm{mmol}_{\mathrm{c}} \mathrm{dm}^{-3}, \mathrm{CTC}$ a pH $7=100 \mathrm{mmol}_{\mathrm{c}} \mathrm{dm}^{-3}$, $\mathrm{V}=58 \%, \mathrm{~m} \%=5$, conforme métodos descritos no item 3.5.1. A análise das formas totais revelou $536 \mathrm{mg} \mathrm{kg}^{-1}$ de $\mathrm{Mn}, 26 \mathrm{mg} \mathrm{kg}^{-1}$ de Cu, $32 \mathrm{mg} \mathrm{kg}^{-1}$ de $\mathrm{Zn} \mathrm{e} 12 \mathrm{mg} \mathrm{kg}^{-1}$ de $\mathrm{Cr}$ extraídos por digestão com $\mathrm{HNO}_{3}+\mathrm{HclO}_{4}+\mathrm{HF}$ (Soltanpour et al., 1982), 87,7 g kg-1 de $\mathrm{Al}_{2} \mathrm{O}_{3}, 63,4 \mathrm{~g} \mathrm{~kg}^{-1}$ de $\mathrm{Fe}_{2} \mathrm{O}_{3}$ e $102 \mathrm{~g} \mathrm{~kg}^{-1}$ de $\mathrm{SiO}_{2}$, obtidos através de ataque sulfúrico 
(Camargo et al., 1986). Os teores totais de $\mathrm{Cd}$, $\mathrm{Ni}$ e $\mathrm{Pb}$ apresentaram-se abaixo do limite de determinação do método analítico empregado.

Quanto à caracterização física, o solo apresentou densidade de $1,47 \mathrm{~g} \mathrm{~cm}^{-3}$ e a seguinte composição granulométrica: $400 \mathrm{~g} \mathrm{~kg}^{-1}$ de argila, $200 \mathrm{~g} \mathrm{~kg}^{-1}$ de silte e $400 \mathrm{~g} \mathrm{~kg}^{-1}$ de areia, determinada pelo método do densímetro (EMBRAPA, 1997).

\subsection{Adubos}

As fontes de fósforo, potássio e nitrogênio utilizadas foram, respectivamente, super fosfato simples, cloreto de potássio e uréia. As características químicas dos adubos encontram-se na Tabela 3.

Tabela 3. Teores totais de alguns metais nos adubos super fosfato simples, cloreto de potássio e uréia utilizados no experimento*

\begin{tabular}{lcccccccc}
\hline \multicolumn{1}{c}{ Adubo } & $\mathrm{Cu}$ & $\mathrm{Fe}$ & $\mathrm{Mn}$ & $\mathrm{Ni}$ & $\mathrm{Cd}$ & $\mathrm{Cr}$ & $\mathrm{Pb}$ & $\mathrm{Zn}$ \\
\cline { 2 - 9 } & & & & & $\mathrm{mg} \mathrm{kg}^{-1}$ & & & \\
Superfosfato simples & 110 & 6050 & 580 & 22 & 10 & 15 & 28 & 320 \\
Cloreto de potássio & 6 & 1028 & 20 & 15 & 0 & 2 & 12 & 39 \\
Uréia & 0 & 21 & 1 & 0 & 0 & 0 & 0 & 1 \\
\hline
\end{tabular}

* Análise segundo metodologia descrita por BRASIL (1983).

\subsection{Resíduo}

Utilizou-se o lodo de esgoto proveniente de digestão anaeróbia (sem tratamento com cal) produzido na Estação de Tratamento das Águas do Ribeirão do Piracicamirim do Município de Piracicaba, SP. A caracterização química da amostra utilizada encontrase na Tabela 4. 
Tabela 4. Caracterização química da amostra de lodo utilizada no experimento

\begin{tabular}{lc}
\hline \multicolumn{1}{c}{ Caracteristica } & Resultado $^{1}$ \\
\hline Umidade $(\%)$ & 73,58 \\
$\mathrm{pH}\left(\mathrm{CaCl}_{2}\right)$ & 6,4 \\
Matéria Orgânica $\left(\mathrm{g} \mathrm{kg}^{-1}\right)$ & 523,60 \\
$\mathrm{C}$ oxidável $\left(\mathrm{g} \mathrm{kg}^{-1}\right)$ & 290,90 \\
$\mathrm{~N}$ total $\left(\mathrm{g} \mathrm{kg}^{-1}\right)$ & 29,10 \\
P total $\left(\mathrm{g} \mathrm{kg}^{-1}\right)$ & 6,02 \\
$\mathrm{~K}$ total $\left(\mathrm{g} \mathrm{kg}^{-1}\right)$ & 1,30 \\
Ca total $\left(\mathrm{g} \mathrm{kg}^{-1}\right)$ & 20,80 \\
Mg total $\left(\mathrm{g} \mathrm{kg}^{-1}\right)$ & 3,50 \\
$\mathrm{~S}$ total $\left(\mathrm{g} \mathrm{kg}^{-1}\right)$ & 8,30 \\
Relação $\mathrm{C} / \mathrm{N}$ & 10 \\
Relação C/P & 21 \\
Fe total $\left(\mathrm{mg} \mathrm{kg}^{-1}\right)$ & 30295,00 \\
Mn total $\left(\mathrm{mg} \mathrm{kg}^{-1}\right)^{1}$ & 173,00 \\
Cu total $\left(\mathrm{mg} \mathrm{kg}^{-1}\right)$ & 192,94 \\
Zn total $\left(\mathrm{mg} \mathrm{kg}^{-1}\right)$ & 943,41 \\
Cd total $\left(\mathrm{mg} \mathrm{kg}^{-1}\right)$ & $*$ \\
Cr total $\left(\mathrm{mg} \mathrm{kg}^{-1}\right)$ & 207,20 \\
Ni total $\left(\mathrm{mg} \mathrm{kg}^{-1}\right)$ & $*$ \\
Pb total $\left(\mathrm{mg} \mathrm{kg}^{-1}\right)$ & 107,56 \\
Na total $\left(\mathrm{mg} \mathrm{kg}^{-1}\right)$ & 523,00 \\
Resultas &
\end{tabular}

Resultados expressos em material seco a $65^{\circ} \mathrm{C}$.

* Elementos encontrados abaixo do limite de determinação do método analítico utilizado.

A determinação do $\mathrm{C}$ oxidável foi realizada tratando-se $0,05 \mathrm{~g}$ do resíduo seco $\mathrm{e}$ moído, com $25 \mathrm{~mL}$ de dicromato de potássio $1 \mathrm{~mol} \mathrm{~L}^{-1}$ e $50 \mathrm{~mL}$ de ácido sulfúrico concentrado, aquecendo-se a mistura por $30 \mathrm{~min}$ sob refiuxo e titulando-se o excesso de dicromato com solução de sulfato ferroso amoniacal $0,1 \mathrm{~mol} \mathrm{~L}^{-1}$.

Os macronutrientes e o $\mathrm{Na}$ foram determinados através da combustão a $550{ }^{\circ} \mathrm{C}$ de $1 \mathrm{~g}$ de lodo, colocada em cadinho, por 3 horas. O material queimado foi transferido 
para beckers de $250 \mathrm{~mL}$, adicionando-se $50 \mathrm{~mL}$ de $\mathrm{HCl}(1+1)$ e fervendo-se por 15 minutos. Após filtragar e completadar o volume do balão de $250 \mathrm{~mL}$ com água, determinaram-se os referidos elementos (Kiehl, 1985).

Para a determinação de metais realizou-se a digestão nitro-perclórica $(1+3)$ de $0,5 \mathrm{~g}$ do resíduo seco e moído, com aquecimento simples, em bloco digestor. O S-total foi determinado pelo método gravimétrico de precipitação do $\mathrm{S}$ pelo cloreto de bário, na forma de sulfato de bário; o P-total foi determinado pelo método colorimétrico e o $\mathrm{N}$ total pelo método semi-micro Kjeldahl (Sarruge \& Hagg, 1974).

\subsection{Tratamentos e delineamento experimental}

Para ambas as fases, o experimento seguiu o delineamento inteiramente casualizado. As parcelas foram compostas por vasos com capacidade de $5 \mathrm{~L}$, sem perfuração na parte inferior para se evitar a lixiviação de elementos.

\subsubsection{Primeira fase}

Os tratamentos constituíram-se de 6 doses de lodo de esgoto, equivalentes a 0 , $10,20,30,40$ e $50 \mathrm{Mg} \mathrm{kg}^{-1}$ (base seca), com 16 repetições, totalizando 96 parcelas, distribuídas aleatoriamente na bancada.

\subsubsection{Segunda fase}

Para esta fase, os tratamentos em arranjo fatorial $6 \times 2 \times 2$ foram constituídos pelas seis doses de lodo de esgoto $\left(0,10,20,30,40\right.$ e $50 \mathrm{Mg} \mathrm{ha}^{-1}$ base seca) utilizadas na fase anterior, somadas a duas doses de fósforo $\left(0 \mathrm{e} 100 \mathrm{mg} \mathrm{kg}^{-1}\right)$ e duas doses de potássio ( 0 e $100 \mathrm{mg} \mathrm{kg}^{-1}$ ), resultando em 24 tratamentos, com 4 repetições, totalizando 96 parcelas distribuídas aleatoriamente na bancada. 


\subsection{Instalaçãodo experimento}

\subsubsection{Primeira fase}

As Tabelas 5 e 6 apresentam as quantidades de macronutrientes e metais adicionadas às amostras de solo em função das diferentes doses de lodo de esgoto.

Quantidades de $3 \mathrm{~kg}$ de terra seca ao ar, passada em peneira de $5 \mathrm{~mm}$ de abertura de malha, foram transferidas para vasos e tratadas com doses crescentes de lodo ( 0 ; 16,$05 ; 32,10 ; 48,15 ; 64,20$ e 80,25 g por vaso) e uma mistura de $\mathrm{CaCO}_{3}$ e $\mathrm{MgCO}_{3}$ p.a (proporção 4 partes de $\mathrm{Ca}(1,44 \mathrm{~g}$ por vaso) +1 parte de $\mathrm{Mg}(0,36 \mathrm{~g}$ por vaso) para elevar a saturação por bases a $70 \%$. As quantidades de água deionizada adicionadas foram correspondentes a $70 \%$ da capacidade de retenção de água do solo, determinada segundo Klute (1986).As terras foram incubadas por 30 dias nos próprios vasos, em temperatura ambiente, repondo-se a água evaporada quando necessário. Cessado o período de incubação, retiraram-se amostras de terra de cada vaso para análise.

Tabela 5. Quantidades de macronutrientes adicionada às amostras de terra em função da aplicação de doses de lodo de esgoto

\begin{tabular}{ccccccc}
\hline Dose de lodo & $\mathrm{N}$ & $\mathrm{P}$ & $\mathrm{K}$ & $\mathrm{Ca}$ & $\mathrm{Mg}$ & $\mathrm{S}$ \\
\hline $\mathrm{Mg} \mathrm{ha}^{-1}$ & 291 & 60 & 13 & 208 & 35 & 83 \\
10 & 582 & 120 & 26 & 416 & 70 & 166 \\
20 & 873 & 181 & 39 & 624 & 105 & 249 \\
30 & 1164 & 241 & 52 & 832 & 140 & 332 \\
40 & 1455 & 301 & 65 & 1040 & 175 & 415 \\
50 & & & & & & \\
\hline
\end{tabular}


Tabela 6. Quantidades de metais adicionada às amostras de terra em função da aplicação de doses de lodo de esgoto

\begin{tabular}{ccccccc}
\hline Dose de lodo & $\mathrm{Fe}$ & $\mathrm{Mn}$ & $\mathrm{Cr}$ & $\mathrm{Cu}$ & $\mathrm{Pb}$ & $\mathrm{Zn}$ \\
\hline $\mathrm{Mg} \mathrm{ha}^{-\mathbf{l}}$ & 303 & 1,7 & 2,1 & 1,9 & 11 & 9 \\
10 & 606 & 3,5 & 4,1 & 3,8 & 22 & 19 \\
20 & 909 & 5,2 & 6,2 & 5,9 & 32 & 28 \\
30 & 1211 & 6,9 & 8,3 & 7,7 & 43 & 38 \\
40 & 1515 & 8,7 & 10,4 & 9,6 & 54 & 48 \\
50 & & & & & & \\
\hline
\end{tabular}

\subsubsection{Segunda fase}

Após o período de incubação das amostras, realizou-se a adubação mineral fosfatada $(3,82 \mathrm{~g}$ de superfofato simples por vaso) e potássica $(0,6 \mathrm{~g}$ de cloreto de potássio por vaso). Após 24 horas foram semeadas 10 sementes de milho (Zea mays L.), híbrido AGX-7393, por vaso e aos 7 dias da germinação foi feito o desbaste, deixandose cinco plantas por vaso. Aos 28 dias da germinação das plantas foi aplicada a adubação nitrogenada (300 $\mathrm{mg}$ de $\mathrm{N}$ por vaso) na forma de uréia, diluída em água, devido ao aparecimento de sintomas visuais de deficiência de N. A irrigação foi feita colocando-se água suficiente para proporcionar ao solo umidade equivalente a $70 \%$ da capacidade de retenção de água, sendo o monitoramento da umidade do solo realizado pela pesagem dos vasos. Semanalmente realizou-se o rodízio dos vasos, visando minimizar o efeito das variações de ambiente a que estavam expostos. Quando as plantas atingiram 50 dias foi coletada a parte aérea (folhas + colmos) para análise. 


\subsection{Análises realizadas}

\subsubsection{Solo}

As amostras de terra retiradas dos vasos após o período de incubação foram secas em estufa e passadas em peneira de $2 \mathrm{~mm}$ de abertura de malha para determinação de:

- $\mathrm{pH}$ em $\mathrm{CaCl}_{2}$ 0,01 mol L $\mathrm{L}^{-1}$, matéria orgânica, $\mathrm{P}, \mathrm{K}, \mathrm{Ca}$ e $\mathrm{Mg}$ extraídos pelo método da resina trocadora de íons, $\mathrm{Al}$ extraído por $\mathrm{KCl} 1 \mathrm{~mol}^{-1}$ e $\mathrm{H}+\mathrm{Al}$ determinado pelo tampão SMP (Raij \& Quaggio, 1983);

- $\mathrm{S}^{-\mathrm{SO}_{4}}$ extraído por acetato de amônio $0,5 \mathrm{~mol} \mathrm{~L}^{-1}$ (Vitti, 1988);

- Na, através da extração com Mehlich-1 (Tedesco et al., 1995);

- Por cálculos, também foram obtidos os seguintes valores: soma de bases (SB); capacidade de troca de cátions (CTC a pH 7), saturação por alumínio (m\%) e saturação por bases (V\%).

- Teores solúveis de metais ( $\mathrm{Fe}, \mathrm{Mn}, \mathrm{Zn}, \mathrm{Cu}, \mathrm{Cd}, \mathrm{Cr}, \mathrm{Ni}$ e $\mathrm{Pb}$ ) foram obtididos através dos seguintes métodos de extração:

a) Extração com $\mathrm{HCl} 0,1 \mathrm{~mol} \mathrm{~L}{ }^{-1}$

Transferiram-se $5 \mathrm{~g}$ de TFSE para frascos cilíndricos de plástico e adicionaramse $25 \mathrm{~mL}$ da solução $\mathrm{HCl} 0,1 \mathrm{~mol} \mathrm{~L}^{-1}$. Deixou-se em repouso por 24 horas (Sauerbeck \& Styperek, 1985). Após a filtragem, as quantidades de metais presentes nos extratos foram determinadas por espectrofotometria de absorção atômica com chama convencional. 


\section{b) Extração com Mehlich-3}

A $2,5 \mathrm{~g}$ de TFSE adicionaram-se $25 \mathrm{~mL}$ da solução extratora Mehlich-3

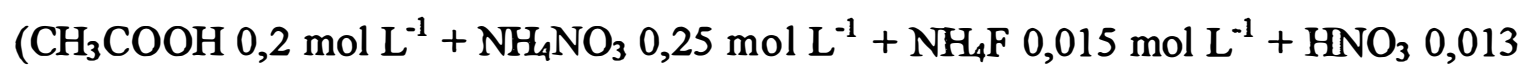
mol $\mathrm{L}^{-1}+$ EDTA $0,001 \mathrm{~mol} \mathrm{~L}^{-1}$ ). Agitou-se por 5 minutos em agitador circularhorizontal, com velocidade de $240 \mathrm{rpm}$ (Mehlich, 1984). Após filtragem, determinou-se a concentração de metais presentes nos extratos por espectrofotometria de absorção atômica com chama convencional.

c) Extração com DTPA 0,005 mol $L^{-1}, p H 7,3$

Quantidades de $20 \mathrm{~g}$ de TFSE foram passadas para frascos cilíndricos de plástico e adicionaram-se $40 \mathrm{~mL}$ da mistura digestora (DTPA $0,005 \mathrm{~mol} \mathrm{~L}^{-1}+$ trietanolamina 0,1 mol L ${ }^{-1}+$ cloreto de cálcio $0,01 \mathrm{~mol} \mathrm{~L}^{-1}$, corrigidos a $\mathrm{pH} 7,3$ ). Agitou-se por 2 horas em agitador circular-horizontal numa velocidade de $240 \mathrm{rpm}$ (Lindsay \& Norvell, 1978).Transferiu-se o filtrado para tubos de ensaio e deteminou-se a quantidade de metais por espectrofotometria de absorção atômica com chama convencional.

\subsubsection{Plantas}

A parte aérea das plantas (colmo + folhas) foi seca em estufa a $60^{\circ} \mathrm{C}$, até massa constante, pesada e moída para a determinação de:

- P, K, Ca, Mg, S Fe e Mn: através de digestão nitro-perclórica (Sarruge \& Haag, 1974). A determinação do $\mathrm{Ca}, \mathrm{Mg}, \mathrm{Fe}$ e $\mathrm{Mn}$ nos extratos obtidos foi realizada por espectrofotometria de absorção atômica com chama convencional. O P-total foi determinado pelo método colorimétrico. Para determinar o teor de $\mathrm{N}$, as amostras foram submetidas à digestão sulfúrica (Sarruge \& Haag, 1974), seguindo-se a quantificação do $\mathrm{N}$ pelo método micro-kjeldahl.

- Para determinar os metais $\mathrm{Zn}, \mathrm{Cu} \mathrm{Cd}, \mathrm{Cr}, \mathrm{Ni}$ e $\mathrm{Pb}$, que estavam em concentrações extremamente baixas, os extratos obtidos através de digestão nitro-perclórica foram 
concentrados, digerindo-se $1000 \mathrm{mg}$ do material com recuperação do extrato em volume de $15 \mathrm{~mL}$. A determinação analítica dos metais foi realizada por espectrofotometria de absorção atômica com chama convencional (Sarruge \& Haag, 1974).

- As quantidades de elementos acumuladas pela parte aérea das plantas foram obtidas através da seguinte fórmula:

Quantidade acumulada (mg/vaso) $=\frac{[\mathrm{M}] \times \mathrm{MS}}{1000}$

Onde:

[M] = concentração do elemento contido na parte aérea das plantas, em $\mathrm{mg} \mathrm{kg}^{-1}$; MS = Produção total de matéria seca da parte aérea das plantas, em g/vaso.

\subsection{Tratamento estatístico dos resultados obtidos}

Os resultados de $\mathrm{MO}, \mathrm{SB}, \mathrm{CTC}, \mathrm{V} \%, \mathrm{~m} \%, \mathrm{H}+\mathrm{Al}, \mathrm{Al}, \mathrm{Na}$, macronutrientes e metais foram submetidos à análise de variância pelo teste $\mathrm{F}$, cujo esquema se encontra na Tabela 7. O efeito das doses de lodo foi avaliado por regressão polinomial de $1^{\circ}$ e $2^{\circ}$ graus.

Tabela 7. Esquema de análise de variância para as variáveis $\mathrm{MO}, \mathrm{SB}, \mathrm{CTC}, \mathrm{V} \%, \mathrm{~m} \%$, $\mathrm{H}+\mathrm{Al}, \mathrm{Al}, \mathrm{Na}$, macronutrientes e metais determinados no solo, após período de incubação

\begin{tabular}{lc}
\hline Causas da Variação & GL \\
\hline Dose de lodo & 5 \\
Resíduo & 90 \\
\hline Total & 95 \\
\hline
\end{tabular}


Os resultados dos teores de $\mathrm{Fe}, \mathrm{Mn}, \mathrm{Cu}$ e $\mathrm{Zn}$ do solo foram submetidos à análise de variância considerando-se os tratamentos em arranjo fatorial envolvendo seis doses de lodo e três métodos de extração (Tabela 8). Os métodos de esxtração foram comparados pelo teste de Tukey ao nível de 5\%. Para avaliar a eficiência dos extratores foram feitas correlações entre resultados dos próprios extratores e entre os extratores e as quantidades de metais acumuladas pelas plantas.

Tabela 8. Esquema de análise de variância para as variáveis $\mathrm{Fe}, \mathrm{Mn}, \mathrm{Cu}$ e $\mathrm{Zn}$ determinados no solo após período de incubação

\begin{tabular}{ll}
\hline Causas da Variação & GL \\
\hline Dose de lodo & 5 \\
Método & 2 \\
Dose de lodo x Método & 10 \\
Resíduo & 78 \\
\hline Total & 95 \\
\hline
\end{tabular}

Para as variáveis determinadas nas plantas, a análise de variância seguiu o delineamento inteiramente casualizado, com os tratamentos doses de lodo, doses de $\mathrm{P} \mathrm{e}$ doses de $\mathrm{K}$, em arranjo fatorial $6 \times 2 \times 2$ (Tabela 9). $\mathrm{O}$ efeito das doses de $\mathrm{P}$ e $\mathrm{K}$ foi avaliado através do teste de Tukey. $\mathrm{O}$ efeito das doses de lodo foi avaliado por meio de regressões polinomiais. 
Tabela 9. Esquema de análise de variância para as variáveis produção de matéria seca, e quantidades de macronutrientes e metais acumuladas pelas plantas

\begin{tabular}{lc}
\hline Causas da Variação & GL \\
\hline Dose de lodo & 5 \\
Dose de P & 1 \\
Dose de K & 1 \\
Dose lodo x Dose de K & 5 \\
Dose lodo x Dose de P & 5 \\
Dose de P x Dose de K & 1 \\
Dose lodo x Dose de P x Dose de K & 5 \\
Resíduo & 72 \\
\hline Total & 95 \\
\hline
\end{tabular}




\section{RESULTADOS E DISCUSSÃO}

\subsection{Propriedades químicas}

\subsubsection{Matéria orgânica, $\mathrm{pH}$, alumínio trocável e saturação por alumínio}

Houve efeito significativo da aplicação do lodo de esgoto sobre o $\mathrm{pH}$, sobre os teores de matéria orgânica e alumínio trocável, e sobre os valores de porcentagem de saturação por alumínio das amostras de terra após trinta dias de incubação (Apêndice 1).

Os teores médios de MO aumentaram de forma linear $\left(\mathrm{R}^{2}=0,970^{* *}\right)$ em função da aplicação das doses de lodo de esgoto (Figura 1). Observa-se que, a aplicação do resíduo promoveu incremento de $6 \%$, a cada dose aplicada. Incrementos significativos nos teores de matéria orgânica, em função da disposição de lodo no solo, também foram encontrados por vários autores (Korentajer, 1991; Melo et al., 1994; Berton et al., 1997).

A adição de até $30 \mathrm{Mg} \mathrm{ha}^{-1}$ de lodo de esgoto proporcionou redução nos valores de $\mathrm{pH}$ de modo quadrático $\left(\mathrm{R}=969^{* *}\right)$ (Figura 1). Entretanto, para as duas maiores doses o pH se manteve constante, sugerindo que a nitrificação, fenômeno responsável pelo decréscimo do $\mathrm{pH}$, tenha sido paralizada pela excessiva acidez do meio. Logan et al. (1997) observaram, em solo derivado de rochas calcárias, no primeiro ano de aplicação de lodo de esgoto não tratado com cal, um decréscimo no valor de $\mathrm{pH}$, para as menores doses de lodo (7,5 e $15 \mathrm{Mg} \mathrm{ha}^{-1}$ ), imediatamente após a aplicação do resíduo. Nas demais doses verificaram aumentos de até duas unidades. Estes autores atribuíram a acidificação às reações de nitrificação do nitrogênio amoniacal, e a elevação do pH, nas 

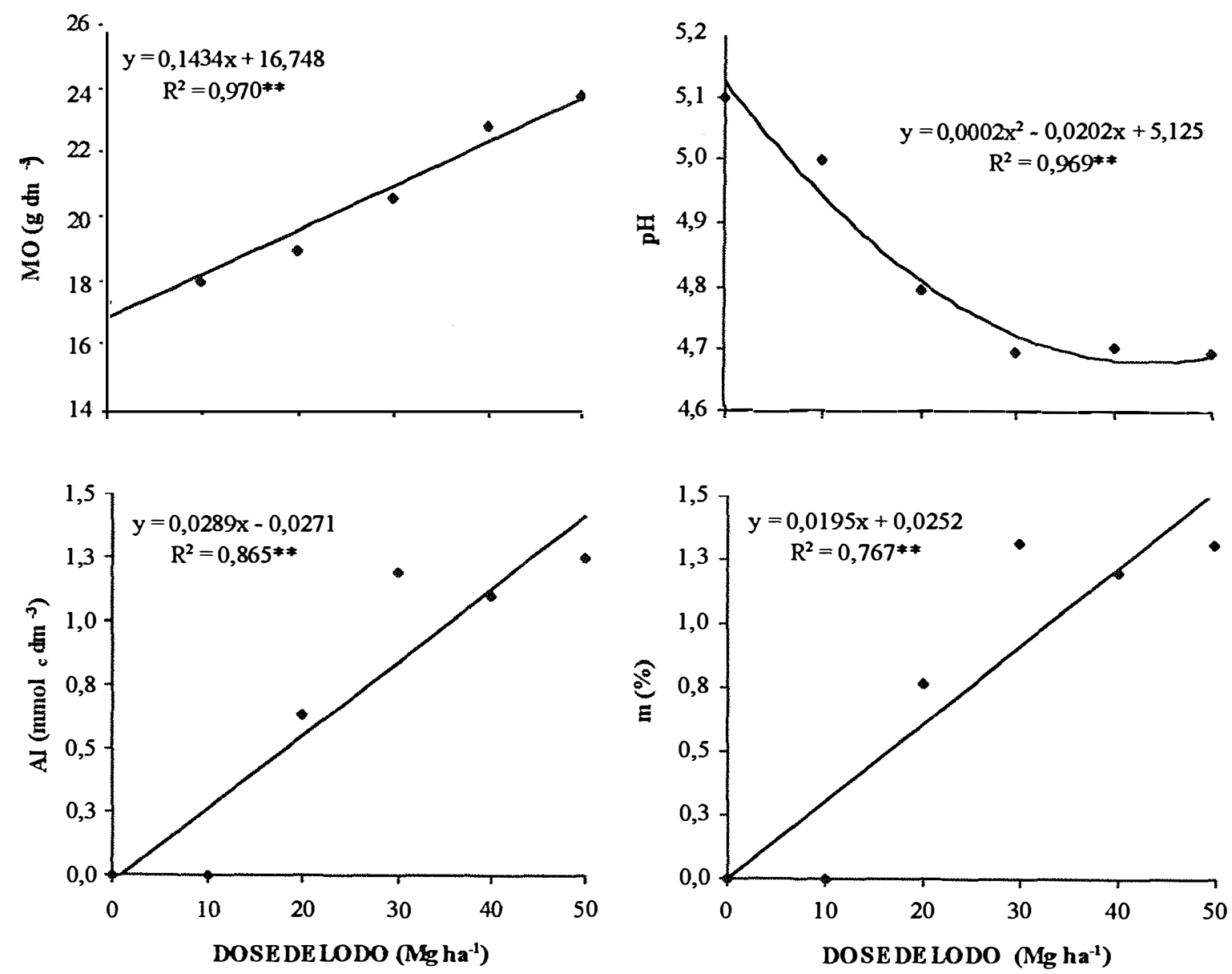

Figura 1. Teores de matéria orgânica (MO), valores de pH, Al-tocável ( $\mathrm{Al}$ ) e saturação por alumínio (m) nas amostras de terra, em função da aplicação de doses de lodo de esgoto, após 30 dias de incubação (** Indica que os termos de regressão foram significativos a $P \leq 0,01$ pelo teste $F$ )

maiores doses, às reações envolvidas na degradação da carga orgânica do resíduo. Contudo, Berton et al. (1989), Sloan \& Basta (1995), Bertoncini \& Mattiazzo (1999) e Oliveira (2000) constataram acréscimos nos valores de pH com a adição de doses crescentes de lodo de esgoto. Estes pesquisadores atribuíram a elevação do $\mathrm{pH}$ à alcalinidade do material utilizado. A discrepância desses resultados deve estar associada às diferentes características dos lodos. Cabe salientar que o lodo utilizado neste trabalho 
não recebeu nenhum tipo de tratamento para higienizar ou para facilitar o processo de desidratação.

O aumento da acidez, em função da aplicação das doses de lodo de esgoto, proporcionou um aumento linear dos teores de alumínio trocável $\left(\mathrm{R}^{2}=0,865^{* *}\right) \mathrm{e}$, conseqüentemente, elevação dos valores de $m \%\left(\mathrm{R}^{2}=0,767^{* *}\right)$ (Figura 1). Segundo Tisdale et al. (1985), o aumento da acidez promove a solubilização das espécies de alumínio. Estes autores relatam que abaixo de $\mathrm{pH} 6,5$ pode-se constatar a presença de alumínio na forma de íon $\mathrm{Al}^{3+}$; no entanto, somente quando o $\mathrm{pH}$ atinge $\mathrm{pH} 4,7, \mathrm{o} \mathrm{Al}^{+3}$ apresenta-se de forma predominante. Através de cálculos, utilizando-se a constante de solubilidade (Ks) do $\mathrm{Al}(\mathrm{OH})_{3}$ (Kolthoff et al., 1969), constatou-se que, a partir do pH 5 , cada redução de 0,1 unidade no $\mathrm{pH}$ promove um incremento em torno de 2 vezes nos teores de alumínio trocável.

\subsubsection{Fósforo e enxofre}

A disponibilidade do fósforo aumentou de forma linear em função das doses de lodo empregadas (Figura 2). O incremento de fósforo devido à adição do resíduo variou, da menor para a maior dose, de $18 \%$ a $110 \%$. Segundo os limites de interpretação de teores de fósforo no solo, estabelecidos para culturas anuais no Estado de São Paulo (Raij et al., 1996), verifica-se que o teor de fósforo disponível passou de classe "Gaixo" (9,3 $\left.\mathrm{mg} \mathrm{dm}^{-3}\right)$, apresentado pela dose $0 \mathrm{Mg} \mathrm{ha}^{-1}$, para “médio" $\left(20,8 \mathrm{mg} \mathrm{dm}^{-3}\right)$ a partir da dose $40 \mathrm{Mg} \mathrm{ha}^{-1}$ de lodo. Resultados similares foram encontrados por Oliveira et al. (1995), Marques (1996), Silva et al. (1998) e Sui \& Thompson (2000), que observaram aumentos lineares significativos de fósforo disponível no solo, após aplicações de lodo de esgoto em doses que variaram de 0 a $160 \mathrm{Mg} \mathrm{ha}^{-1}$. 

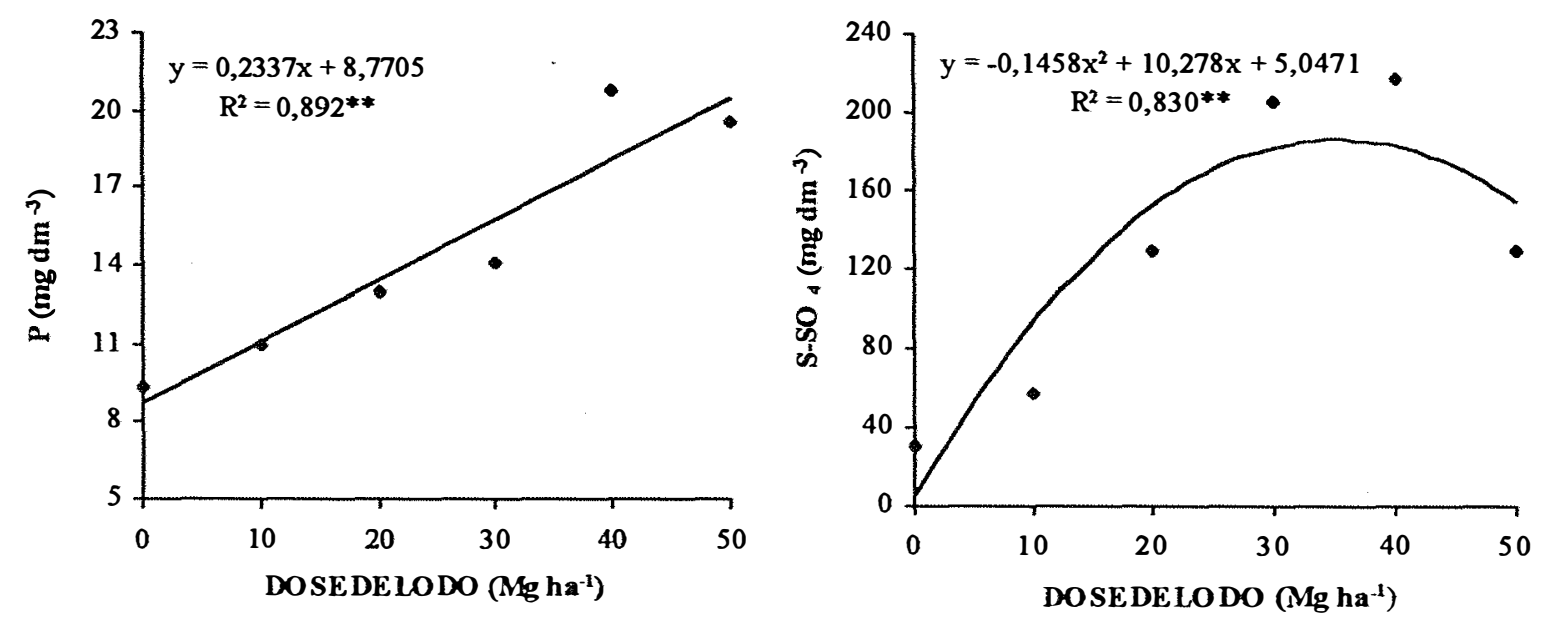

Figura 2. Teores de fósforo e enxofre $\left(\mathrm{S}_{-} \mathrm{SO}_{4}\right)$ nas amostras de terra, em função das doses de lodo de esgoto, após 30 dias de incubação (** Indica que os termos de regressão foram significativos a $P \leq 0,01$ pelo teste $F$ )

A variação do teor de enxofre $\left(\mathrm{S}^{\left.-\mathrm{SO}_{4}\right)}\right.$ em função das doses de lodo aplicado ajustou-se à equação de regressão quadrática (Figura 2). $\mathrm{O}$ teor inicial $\left(30,8 \mathrm{mg} \mathrm{dm}^{-3}\right)$, que já era considerado alto (Raij et al. 1996), apresentou incrementos expressivos com a adição do lodo. A partir da dose de $10 \mathrm{Mg} \mathrm{ha}^{-1}$ de lodo ocorreu aumento de $90 \%$ nos teores de $\mathrm{S}_{-} \mathrm{SO}_{4}$, em relação ao tratamento com $0 \mathrm{Mg} \mathrm{ha}^{-1}$, chegando a aproximadamente $600 \%$ entre as doses 30 e $40 \mathrm{Mg} \mathrm{ha}^{-1}$ de lodo. Silva et al. (1998), avaliando o lodo de esgoto como fonte de nutrientes para a cultura da cana-de-açúcar, constataram aumentos de $115 \%$ e $161 \%$ nos teores de enxofre disponível no solo, quando adicionaram doses de 15 e $30 \mathrm{Mg} \mathrm{ha}^{-1}$ de lodo, respectivamente. Observa-se, também, que houve redução no teor disponível deste elemento quando foram aplicados $50 \mathrm{Mg} \mathrm{ha}^{-1}$ de lodo, em relação aos tratamentos que receberam 30 e $40 \mathrm{Mg} \mathrm{ha}^{-1}$. Este decréscimo pode estar associado a uma possível redução da mineralização da matéria orgânica neste tratamento. Como a maior parte do enxofre está combinada com a matéria orgânica, é fundamental que a mesma seja mineralizada para que ocorra sua liberação (Garcia Junior, 1992). Comportamento similar para o enxofre foi observado por Silva (1995), quando adicionou doses de 0, 20 e $40 \mathrm{Mg} \mathrm{ha}^{-1}$ (com $62 \%$ de umidade) 
ao solo. Este autor constatou que aos 146 dias da aplicação, o teor de enxofre no solo apresentou comportamento quadrático, com elevação até a dose de $20 \mathrm{Mg} \mathrm{ha}^{-1} \mathrm{e}$ decréscimo na maior dose.

\section{1. 3 Cátions trocáveis}

Na Figura 3 são apresentadas as regressões para os teores médios dos elementos potássio, cálcio, magnésio e sódio, em função da incorporação de doses crescentes de lodo de esgoto.

Para o potássio, embora a variação do teor no solo com a aplicação das doses de lodo tenham sido linear, o coeficiente de determinação foi baixo $\left(\mathrm{R}^{2}=0,474^{* *}\right)$. A variação apresentada pelo potássio, em função da aplicação do resíduo, não foi suficiente para mudança de classe de teor, que era classificado como baixo (Raij, et al., 1996). Silva et al. (1998), estudando o efeito do lodo de esgoto como fonte de nutriente para a cana-de-açúcar, verificaram que a adição de 15 e $30 \mathrm{Mg} \mathrm{ha}^{-1}$ promoveu reduções nos teores de potássio trocáveis do solo. Segundo Hungria \& Urquiaga (1992), a microflora do solo tem influência no nível de potássio disponível, especialmente em solos pobres, podendo ocorrer imobilização de potássio por parte dos mesmos. Porém, essa imobilização é apenas temporária e, com a morte dos microrganismos, o potássio é liberado das células por mineralização.

A pequena contribuição do lodo para o teor de potássio do solo deve-se ao fato deste elemento ser bastante solúvel e não estrutural, e não ficar retido na fração orgânica do lodo, perdendo-se com o efluente durante o processo de tratamento de esgoto. $\mathrm{O}$ resíduo utilizado neste rabalho, por exemplo, apresentou teor total de apenas $1,3 \mathrm{~g} \mathrm{~kg}^{-1}$ de $\mathrm{K}$, comprovando assim que o lodo de esgoto não é uma boa fonte de potássio. 

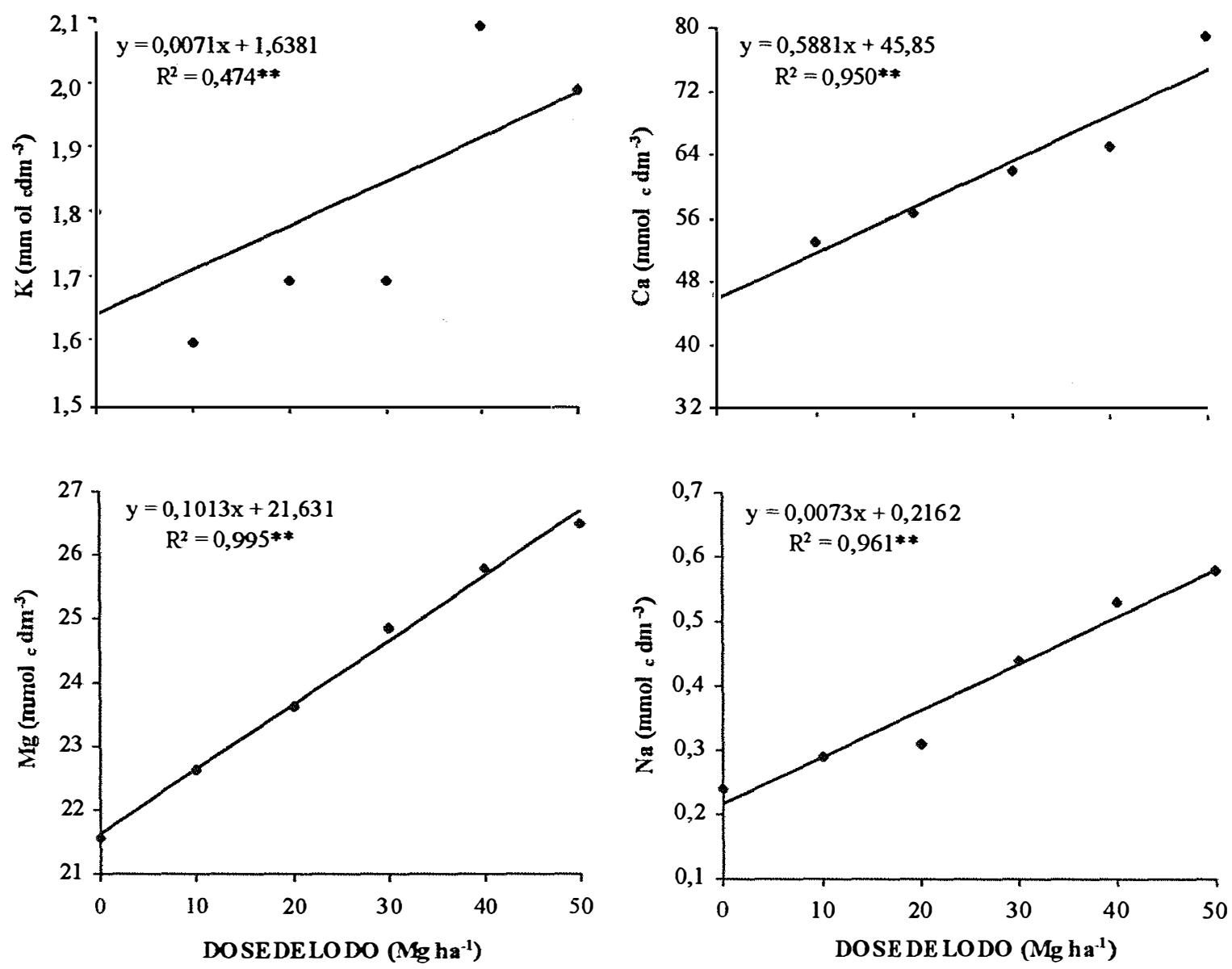

Figura 3. Teores trováveis de potássio, cálcio, magnésio e sódio nas amostras de terra, em função da adição de doses de lodo de esgoto, após 30 dias de incubação ( ${ }^{* *}$ Indica que os termos de regressão foram significativos a $\mathrm{P} \leq$ 0,01 pelo teste $\mathrm{F}$ )

Os teores de cálcio e magnésio no tratamento sem aplicação de lodo $(46,31$ e $21,56 \mathrm{mmol}_{\mathrm{c}} \mathrm{dm}^{-3}$, respectivamente), que já eram considerados altos (Raij et al. 1996), foram aumentados de forma linear com a adição de lodo, variando da menor para a maior dose, de $15 \%$ a $70 \%$ e de $5 \%$ a $23 \%$, respectivamente para cálcio e magnésio. Aumentos consideráveis destes elementos, com a adição de lodo de esgoto, também foram observados por vários autores (Melo et al., 1994; Marques, 1996; Souza et al., 
1998; Oliveira, 2000). Entretanto, o uso de resíduos tratados com cal poderá causar problemas relacionados com desbalanço de nutrientes no solo, principalmente com relação aos teores trocáveis de cálcio, magnésio e potássio. Bertoncini (1997), trabalhando em solos Areia Quartzosa, Latossolo Vermelho-Amarelo e Latossolo Vermelho Escuro tratados com $156 \mathrm{Mg} \mathrm{ha}^{-1}$ (base seca) de lodo tratado com cal, verificou que a adição do resíduo proporcionou desbalanço nutricional nas relações Ca:Mg e \%Ca:CTC, sendo que o cálcio ocupou mais de $90 \%$ da CTC. A relação ideal para a maioria das plantas é em torno de 60\% a $70 \%$ (PPI, 1978).

Para o sódio, que se encontrava em menor quantidade no resíduo $\left(0,52 \mathrm{~g} \mathrm{~kg}^{-1}\right)$, em relação ao potássio $\left(1,3 \mathrm{~g} \mathrm{~kg}^{-1}\right)$, constataram-se acréscimos médios variando da menor para a maior dose aplicada, de $22 \%$ a $145 \%$. Devido à semelhança química, ao comportamento no solo e às quantidades presentes no resíduo, entre o potássio e o sódio, esperava-se que o potássio apresentasse comportamento similar ao do sódio, o que não foi observado, uma vez que o potássio apresentou comportamento irregular.

\subsubsection{Soma de bases (SB), H+Al, capacidade de troca de cátions (CTC a pH 7) e saturação por bases (V)}

Através da análise de variância foram verificados efeitos significativos da aplicação do lodo de esgoto sobre os valores de SB, CTC a pH 7 e teores de $\mathrm{H}+\mathrm{Al}$. (Apêndice 1), tendo esses aumentos sido lineares (Figura 4).

Em decorrência dos aumentos dos teores trocáveis de $\mathrm{Ca}, \mathrm{Mg}$ e $\mathrm{Na}$ (para todas as doses de lodo aplicadas) e de $\mathrm{K}$ (nas doses de 40 e $50 \mathrm{Mg} \mathrm{ha}^{-1}$ ) devido à aplicação do resíduo, verificou-se um aumento proporcional na SB do solo.

A adição de doses de lodo proporcionou incrementos crescentes na CTC que se ajustaram de forma linear $\left(\mathrm{R}^{2}=0,987^{* *}\right)$. Vários autores têm constatado aumento da CTC em função da aplicação de lodo de esgoto (Simeoni et al. 1984; Melo et al. 1994; Cavallaro et al., 1993). Em todos esses trabalhos, esses comportamento têm sido atribuídos aos acréscimos de matéria orgânica nos solos, proporcionados pelas adições de lodo de esgoto. 

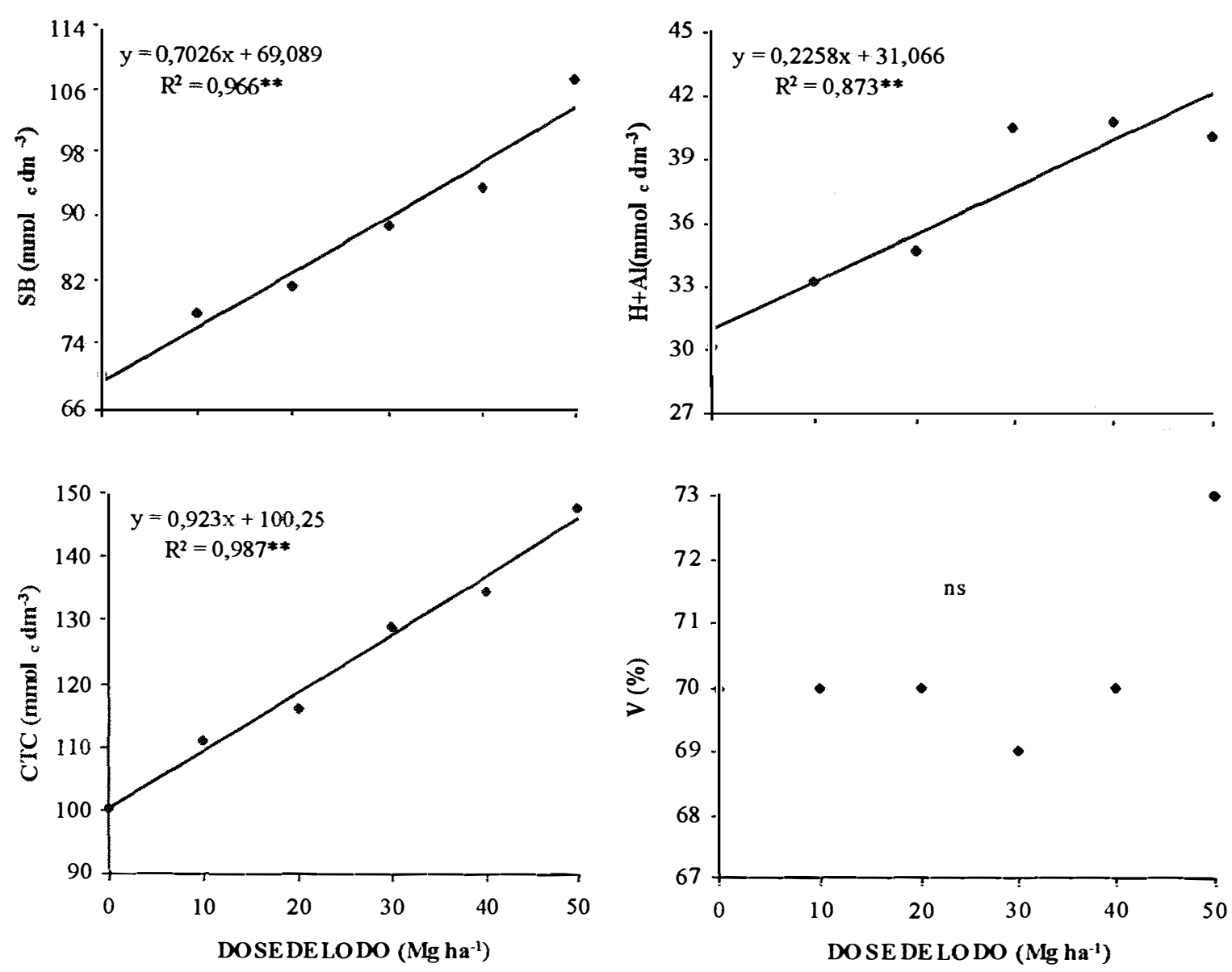

Figura 4. Soma de bases (SB), H+Al, capacidade de troca de cátions potencial (CTC) e saturação por bases nas amostras de terra, em função da aplicação de doses de lodo de esgoto, após 30 dias de incubação (**Modelo ajustado a $\mathrm{P} \leq 0,01$ pelo teste F)

Silva (1995), aplicando doses de 0, 20 e $40 \mathrm{Mg} \mathrm{ha}^{-1}$ (com 62\% de umidade) de lodo de esgoto em Podzólico Vermelho-Amarelo, observou aumentos na CTC estimada através da soma de bases. Entretanto, há de se considerar que nesse trabalho, além de o lodo utilizado ter sido tratado com cal, que pode mascarar os efeitos na CTC pela elevação do $\mathrm{pH}$ dos solos, a CTC também poderia estar sendo superestimada pelas altas doses de $\mathrm{Ca}$ adicionadas via lodo de esgoto, o que não é o caso deste trabalho, uma vez que o lodo utilizado não foi tratado com cal. 
Como a fração húmica da matéria orgânica apresenta grande concentração de radicais carboxílicos, fenólicos, alcoóis e metoxílicos, conferindo uma quantidade de carga em torno de 4000-8000 $\mathrm{mmol}_{\mathrm{c}} \mathrm{kg}^{-1}$ (Canellas et al., 1999), acredita-se que a redução de aproximadamente 0,4 unidade nos valores de $\mathrm{pH}$ (Figura 1), não foi suficiente para afetar, de maneira significativa, a contribuição de cargas oferecida pela fração húmica da matéria orgânica.

Não houve efeito significativo da aplicação do lodo de esgoto sobre a saturação por bases das amostras de terra, após o período de incubação (Apêndice 1). Os valores de V\% mantiveram-se praticamente inalterados com a adição das doses do resíduo, provavelmente pelo fato de que a soma de bases e a CTC a pH 7 aumentaram em proporções semelhantes (Figura 4).

\subsection{Metais no solo e na planta}

\subsubsection{Avaliação de extratores}

As quantidades totais de metais adicionadas ao solo, em função da incorporação das doses crescentes de lodo de esgoto, encontram-se na Tabela 10. Para o Ni e Cd, esses valores não são apresentados porque os teores se apresentaram abaixo do limite de determinação do método analítico empregado.

Os teores de $\mathrm{Cd}, \mathrm{Cr}$, $\mathrm{Ni}$ e $\mathrm{Pb}$ eventualmente extraídos do solo pelas soluções $\mathrm{HCl}$ $0,1 \mathrm{~mol} \mathrm{~L}^{-1}$, Mehlich-3 e DTPA apresentaram-se, para todos os tratamentos, abaixo do limite de determinação do método analítico utilizado, razão pela qual não serão mostrados. Anjos (1999), rabalhando com os solos Latossolo Roxo (LR) e Latossolo Vermelho-Amarelo (LV) tratados com diferentes doses de lodo, que totalizaram $388 \mathrm{Mg}$ ha $^{-1}$ (base seca), verificou que os teores de $\mathrm{Cd}$ e $\mathrm{Pb}$, avaliados pelos extratores $\mathrm{HCl} 0,1$ mol L ${ }^{-1}$, Mehlich-3 e DTPA, estiveram abaixo do limite de determinação do método empregado no trabalho. Para o $\mathrm{Cr}$, constatou que no $\mathrm{LV}$ os extratores $\mathrm{HCl} 0,1 \mathrm{~mol} \mathrm{~L}^{-1}$ e Mehlich-3 extraíram, respectivamente, $9 \%$ e $3 \%$ do total adicionado. No LR, somente o 
Mehlich-3 conseguiu extrair aproximadamente 2\%. Quanto ao Ni, o autor verificou que os extratores $\mathrm{HCl} \mathrm{0,1} \mathrm{mol} \mathrm{L^{-1 }}$, Mehlich-3 e DTPA removeram, respectivamente, 30\%, $20 \%$ e $4 \%$ do total adicionado no $L V$, e no LR as quantidades de $6 \%, 16 \%$ e $8 \%$, respectivamente.

Oliveira (2000), em condições de campo, avaliando a fitodisponibilidade de metais pesados por diferentes extratores, em Latossolo Vermelho-Amarelo tratado com 33, 66 e $99 \mathrm{Mg} \mathrm{ha}^{-1}$ (base seca) de lodo no primeiro ano e 37, 74 e $110 \mathrm{Mg} \mathrm{ha}^{-1}$ (base seca) no segundo ano, constatou que os teores de $\mathrm{Cd}, \mathrm{Cr}$ e $\mathrm{Pb}$, avaliados pelos extratores $\mathrm{HCl}$ 0,1 mol L $\mathrm{L}^{-1}$, Mehlich-3 e DTPA, estiveram abaixo do limite de determinação do método analítico utilizado no trabalho. Para o Ni, constatou remoção média de $8 \%, 28 \%$ e $23 \%$, respectivamente, para os extratores $\mathrm{HCl} \mathrm{0,1} \mathrm{mol} \mathrm{L}{ }^{-1}$, Mehlich-3 e DTPA.

Tabela 10. Quantidades de metais adicionadas às amostras de terra em função da adição das doses de lodo de esgoto

\begin{tabular}{ccccccc}
\hline Dose de lodo & Ferro & Manganês & Cromo & Chumbo & Cobre & Zinco \\
\hline Mg ha $^{-1}$ & & & & & \\
10 & 162,08 & 0,92 & 1,11 & 0,58 & 1,03 & 5,05 \\
20 & 324,16 & 1,85 & 2,22 & 1,15 & 2,06 & 10,09 \\
30 & 486,23 & 2,78 & 3,33 & 1,73 & 3,10 & 15,14 \\
40 & 648,31 & 3,70 & 4,43 & 2,30 & 4,13 & 20,19 \\
50 & 810,39 & 4,63 & 5,54 & 2,88 & 5,16 & 25,24 \\
\hline
\end{tabular}

As quantidades de $\mathrm{Fe}, \mathrm{Mn}, \mathrm{Cu}$ e $\mathrm{Zn}$ removidas pelos extratores das amostras tratadas com doses crescentes de lodo são apresentadas na Tabela 11. Considerando as quantidades desses metais adicionadas ao solo via lodo de esgoto (Tabela 10), é possível estimar que a quantidade média de ferro extraída foi de $48 \%, 13 \%$ e $5 \%$, respectivamente, para os extratores $\mathrm{HCl} \mathrm{0,1} \mathrm{mol} \mathrm{L}{ }^{-1}$, Mehlich-3 e DTPA; para o cobre, 
tais valores foram de $52 \%, 37 \%$ e $26 \%$, e para o zinco, de $80 \%, 59 \%$ e $43 \%$, respectivamente.

Quanto ao manganês, as soluções $\mathrm{HCl}$ 0,1 mol L ${ }^{-1}$, Mehlich-3 e DTPA extraíram, respestivamente, $1407 \%, 619 \%$ e $133 \%$ acima das quantidades adicionadas via resíduo. Esse comportamento está, provavelmente, relacionado à redução do pH do solo (Figura 1). Segundo Borkert (1991), a solubilidade do Mn no solo é altamente dependente do $\mathrm{pH}$ e do potencial redox. Em solos bem drenados, a solubilidade do Mn aumenta com o aumento da acidez do solo, sendo que a concentração de manganês na solução pode aumentar em 100 vezes para cada unidade de decréscimo de pH (Tisdale et al., 1985). Trabalhando em solos Areia Quartzosa e Latossolo Roxo, com níveis de $\mathrm{pH}$ ajustados para 3,9 e 4,9, e posteriormente tratados com 0; 13,5; 29,7 e 40,5 $\mathrm{Mg} \mathrm{ha}^{-1}$ (base seca) de lodo de esgoto, Oliveira (1995) verificou que as soluções $\mathrm{HCl} 0,1 \mathrm{~mol} \mathrm{~L}^{-1}$ e DTPA extraíram mais de Mn do que as quantidades adicionadas ao solo via lodo de esgoto.

As soluções ácidas (extratores $\mathrm{HCl} 0,1 \mathrm{~mol} \mathrm{~L}^{-1}$ e Mehlich-3) extraíram, nos tratamentos que receberam doses dos resíduo, quantidades significativamente superiores de $\mathrm{Fe}, \mathrm{Mn}, \mathrm{Cu}$ e $\mathrm{Zn}$ em relação à solução quelante (DTPA), apresentando a seguinte ordem de extração: $\mathrm{HCl} 0,1 \mathrm{~mol} \mathrm{~L}^{-1}>$ Mehlich-3 > DTPA. A exceção foi para o Cu, nos tratamentos que receberam doses de 10 e $50 \mathrm{Mg} \mathrm{ha}^{-1}$ de lodo, onde o Mehlich-3 e DTPA não diferiram significativamente na capacidade de extração. Esses resultados eram esperados, uma vez que as soluções ácidas extraem quantidades próximas do total devido ao seu potencial em dissolver certas estruturas que retém metais no solo (Abreu, et al., 1995). De forma concordante, Mulchi et al. (1991), trabalhando com solos franco siltoso e franco arenoso, tratados com diferentes tipos de lodo, verificaram que os extratores ácidos (Mehlich-1 e Mehlich-3) foram superiores na extração dos metais Fe, $\mathrm{Mn}$ e $\mathrm{Zn}$, em relação ao extrator DTPA, para todas as doses e tipos de lodos utilizados. Quanto ao $\mathrm{Cu}$, contataram que, para os solos tratados com lodo digerido desidratado e lodo digerido alcalinizado, os extratores ácidos foram superiores ao DTPA, porém, para os solos com composto de lodo alcalinizado e lodo tratado com Fe e submetido a aquecimento, o extrator DTPA foi superior ao extratores ácidos. 
Tabela 11. Teores de ferro, manganês, cobre e zinco removidos por diferentes extratores em função da aplicação de doses de lodo de esgoto

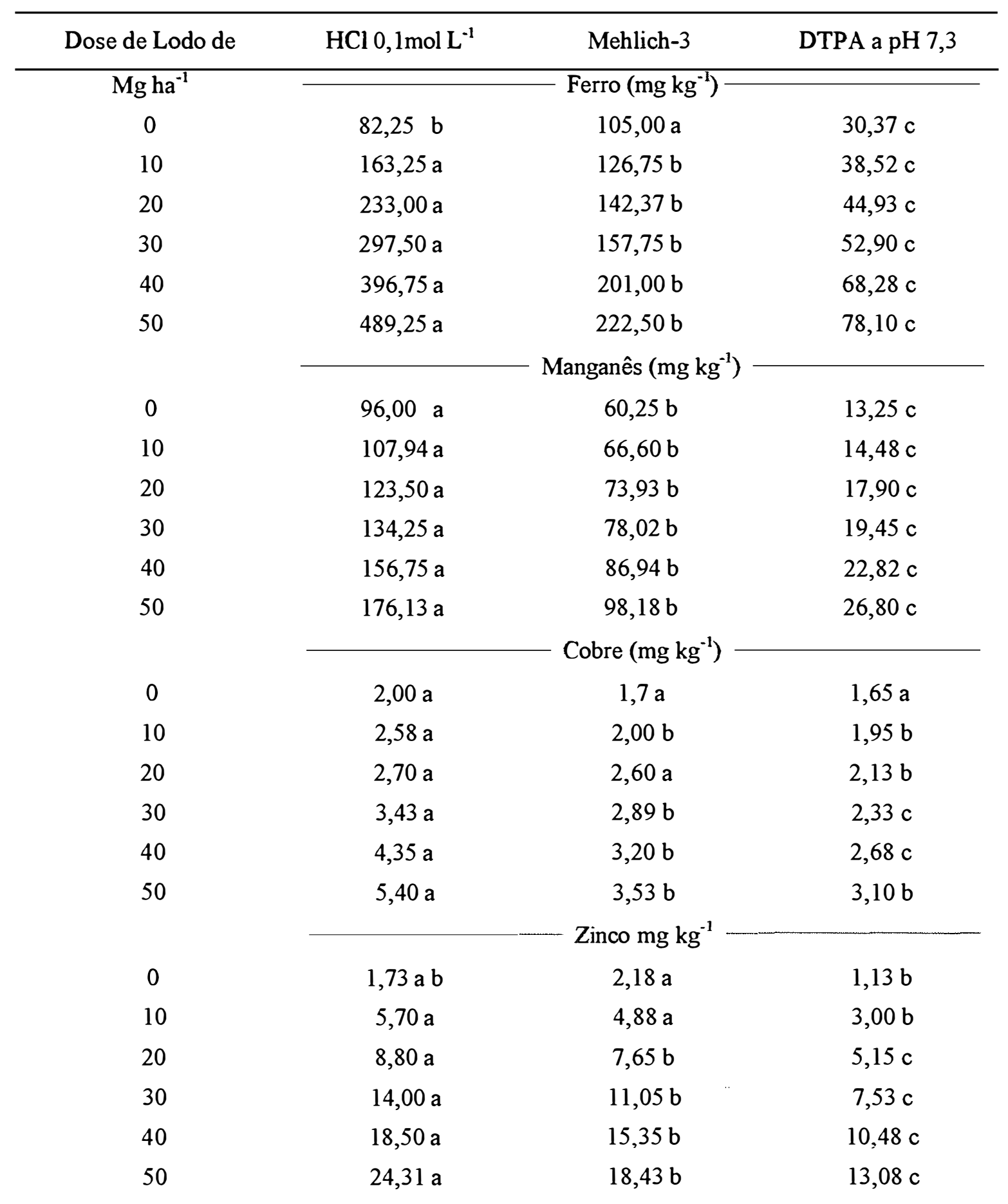

Médias seguidas de letras distintas na horizontal diferem entre si pelo teste de Tukey ao nível de $5 \%$. 
No tratamento sem aplicação de lodo, observou-se que o Mehlich-3 extraiu maior

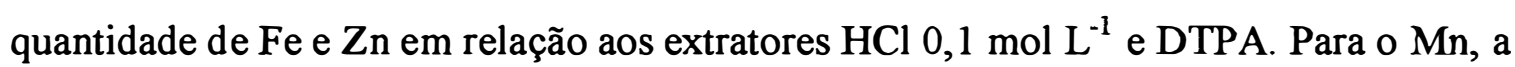
ordem de extração foi $\mathrm{HCl} 0,1 \mathrm{~mol} \mathrm{~L}^{-1}>$ Mehlich-3 > DTPA. No entanto, as quantidades extraídas de $\mathrm{Cu}$, pelos diferentes métodos, não apresentam diferença significativa.

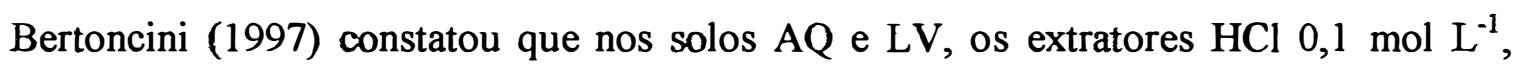
Mehlich-3 DTPA não diferiram entre si na determinação dos teores solúveis de $\mathrm{Cu}$,

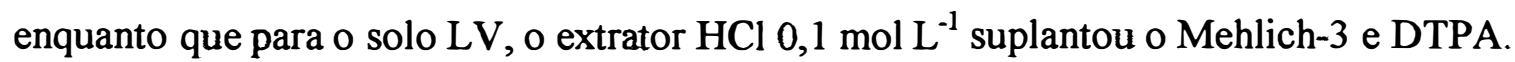
Para o $\mathrm{Zn}$, o autor verificou que três métodos estudados não apresentaram diferenças significativas na extração do elemento nos solos AQ, LV e LE.

A aplicação de doses de lodo de esgoto proporcionou aumentos crescentes nos teores de $\mathrm{Fe}, \mathrm{Mn}, \mathrm{Cu}$ e $\mathrm{Zn}$ removidos pelas soluções extratoras (Figuras 5, 6, 7 e 8, respectivamente). O ferro e o zinco foram os metais que apresentaram maiores incrementos nos teores solúveis, em função das disposições do lodo de esgoto. Isto se explica pelas concentrações elevadas destes metais no resíduo $(30295,00$ e 943,41 mg $\mathrm{kg}^{-1}$, respectivamente). Para o ferro, foram observados acréscimos médios em relação à testemunha, variando da menor para a maior dose aplicada, de $98 \%$ a $595 \%, 21 \%$ a

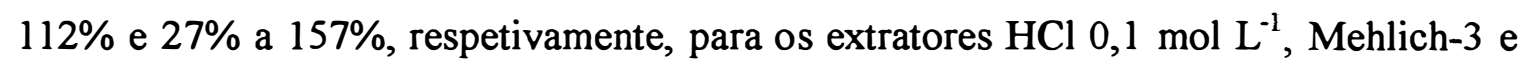
DTPA. No caso do zinco, esses acréscimos variaram de $229 \%$ a $1305 \%$, $124 \%$ a $745 \%$ e $166 \%$ a $1058 \%$, respectivamente. Oliveira (2000), aplicando do lodo de esgoto em solo cultivado com cana-de-açúcar, encontrou maior acréscimo para teores de zinco, em relação a outros metais. Este autor atribuiu o acréscimo do metal à elevada quantidade do mesmo no resíduo. 


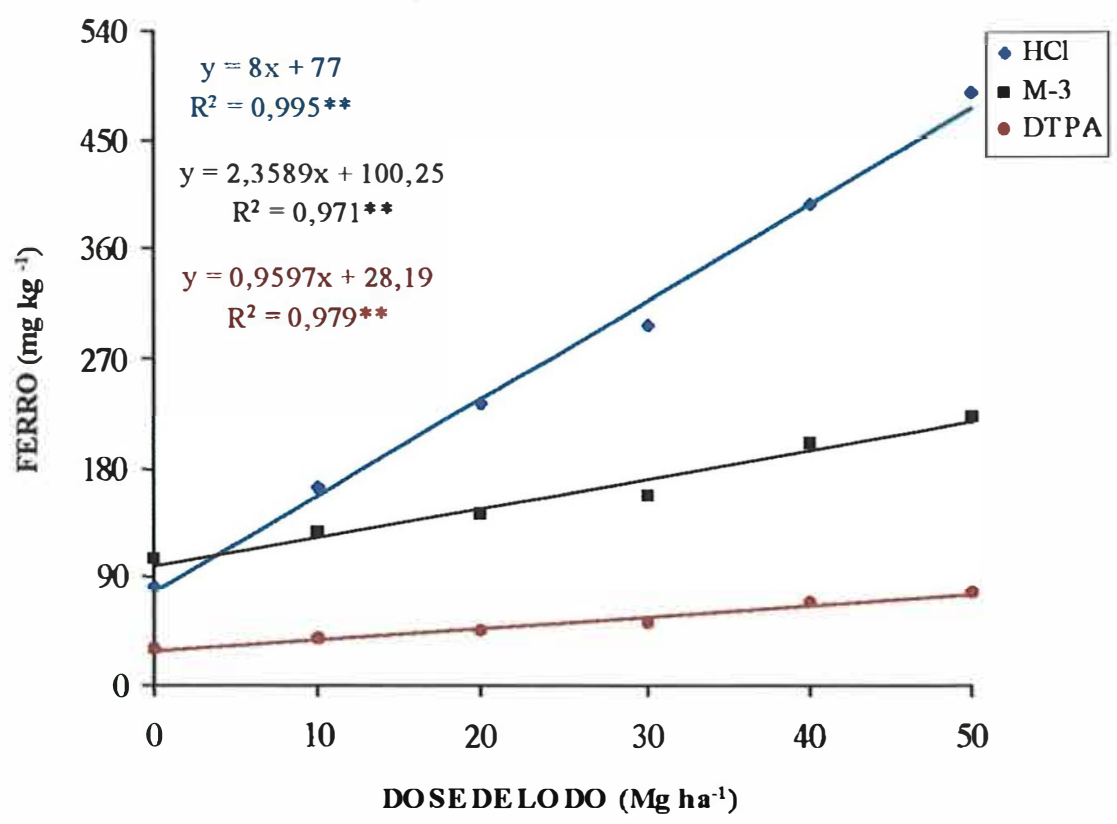

Figura 5. Teores de ferro extraídos pelos extratores $\mathrm{HCL} 0,1 \mathrm{~mol} \mathrm{~L}^{-1}(\mathrm{HCl})$, Mehlich-3 (M-3) e DTPA em função da aplicação de lodo

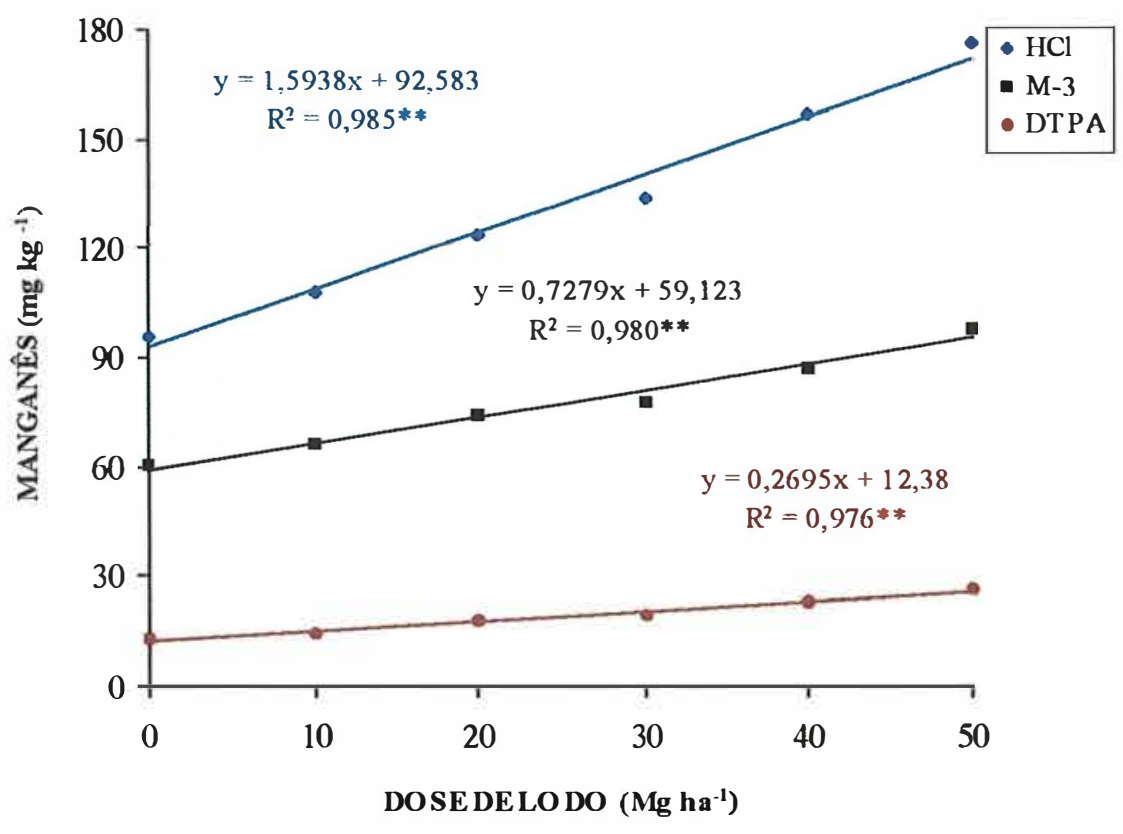

Figura 6. Teores de manganês extraídos pelos extratores $\mathrm{HCL} 0,1 \mathrm{~mol} \mathrm{~L}^{-1}(\mathrm{HCl})$, Mehlich-3 (M-3) e DTPA em função da aplicação de lodo 


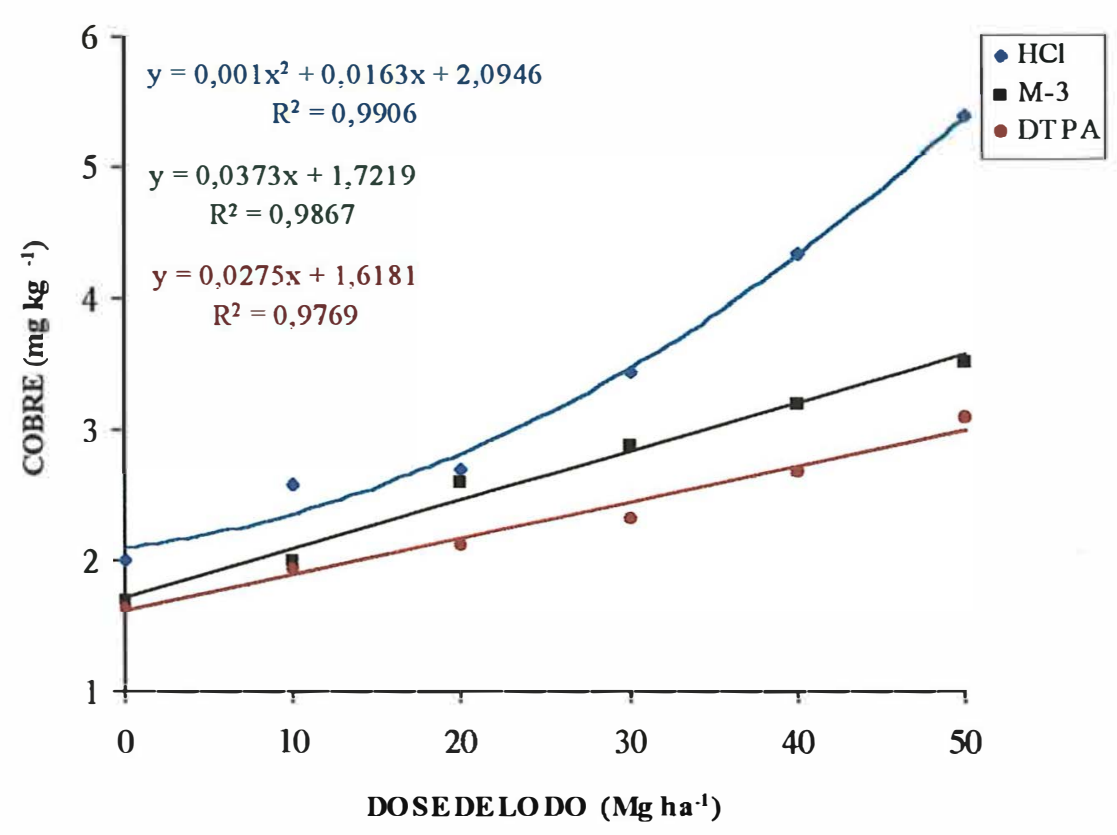

Figura 7. Teores de cobre extraídos pelos extratores $\mathrm{HCL} 0,1 \mathrm{~mol} \mathrm{~L}^{-1}(\mathrm{HCl})$, Mehlich-3 (M-3) e DTPA em função da aplicação de lodo

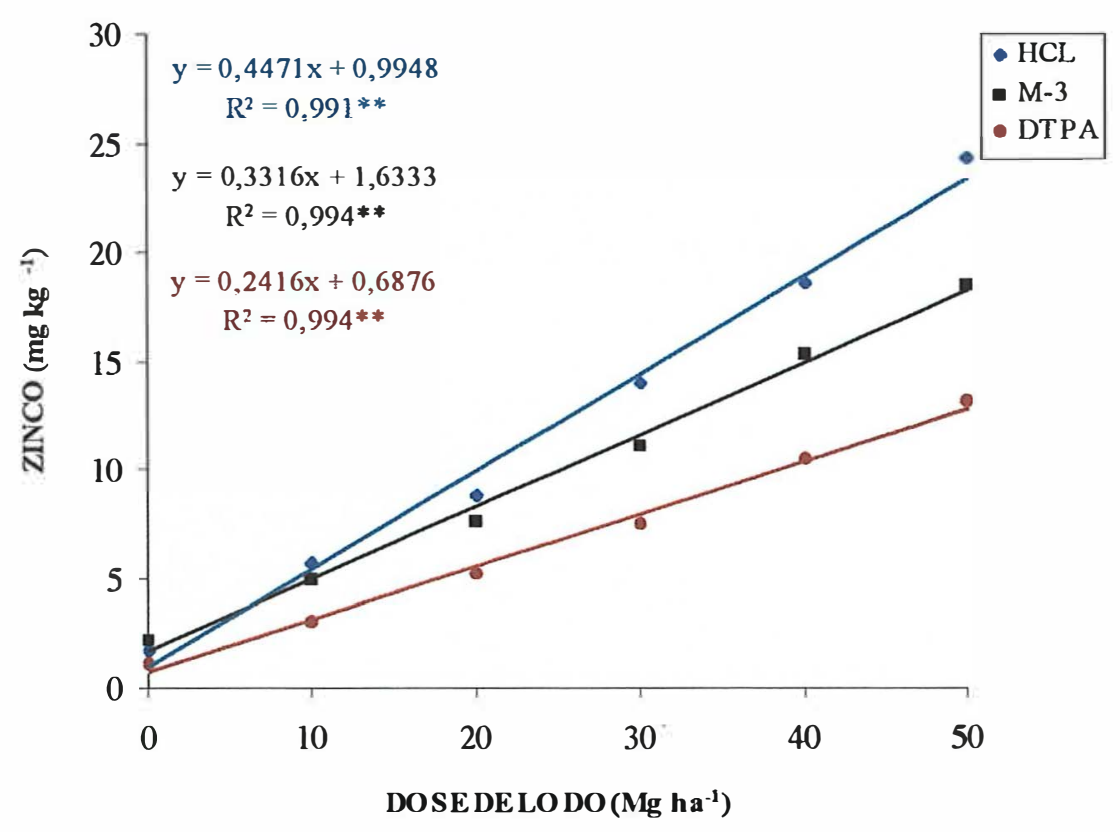

Figura 8. Teores de zinco extraídos por HCL 0,1 mol L ${ }^{-1}(\mathrm{HCl})$, Mehlich-3 (M-3) e DTPA em função da aplicação de doses de lodo de esgoto 
Os teores de cobre aumentaram, em média, de $29 \%$ a $170 \%, 15 \%$ a $103 \%$ e $18 \%$ a $88 \%$, respectivamente, para os extratores $\mathrm{HCl} \mathrm{0,1} \mathrm{mol} \mathrm{L^{-1 }}$, Mehlich-3 DTPA. Para o manganês, os aumentos variaram de $12 \%$ a $83 \%$, de $10 \%$ a $63 \%$ e de $11 \%$ a $99 \%$, respectivamente. Aumentos nos teores disponíveis de ferro, cobre, manganês e zinco com a disposição de lodo de esgoto no solo também foram observados por Rappaport et al. (1988); Mulchi et al. (1991); Hooda \& Alloway, (1993); Berton et al. (1997) e Hooda et al.(1997).

Embora os extratores tenham apresentado diferenças significativas na capacidade de extração dos metais, observa-se que houve correlações significativas entre todos os métodos para os elementos $\mathrm{Fe}, \mathrm{Mn}, \mathrm{Cu}$ e $\mathrm{Zn}$ (Tabela 12). Portanto, todos os extratores fornecem, de maneira geral, informações semelhantes na disponibilidades desses metais em função da adição de doses crescentes do resíduo, exceto para o cobre e manganês que apresentaram baixo índice de correlação entre os extratores Mehlich-3 e DTPA e entre o $\mathrm{HCl} 0,1 \mathrm{~mol} \mathrm{~L}^{-1}$ e o Mehlich-3. Correlações significativas entre os extratores $\mathrm{HCl}$ 0,1 mol L ${ }^{-1}$, Mehlich-3 e DTPA na determinação dos teores de $\mathrm{Cu}$ e $\mathrm{Zn}$ foi encontrada por Oliveira (2000), em Latossolo Vermelho-Amarelo tratado ou não com lodo de esgoto.

Tabela 12. Coeficiente de correlação linear simples para os teores de ferro, manganês, cobre e zinco entre os extratores $\mathrm{HCl} \mathrm{0,1} \mathrm{mol} \mathrm{L}{ }^{-1}(\mathrm{HCl})$, Mehlich-3 (M-3) e DTPA

\begin{tabular}{|c|c|c|c|c|c|c|c|c|}
\hline \multirow[b]{2}{*}{ Extratores } & \multicolumn{2}{|c|}{ Ferro } & \multicolumn{2}{|c|}{ Manganês } & \multicolumn{2}{|c|}{ Cobre } & \multicolumn{2}{|c|}{ Zinco } \\
\hline & $\mathrm{HCl}$ & M-3 & $\mathrm{HCl}$ & $\mathbf{M}-3$ & $\mathrm{HCl}$ & M-3 & $\mathrm{HCl}$ & M-3 \\
\hline DTPA & $0,94^{* *}$ & $0,93 * *$ & $0,81^{* *}$ & $0,66^{* *}$ & $0,95^{* *}$ & $0,60 * *$ & $0,99 * *$ & $0,97^{* *}$ \\
\hline M-3 & $0,95 * *$ & - & $0,60 * *$ & - & $0,64 * *$ & - & $0,97 * *$ & - \\
\hline
\end{tabular}

** Indica que as correlações foram significativas a $\mathrm{P} \leq 0,01$ pelo teste $\mathrm{t}$. 


\section{2. 2 Acúmulo de metais nas plantas}

Os resultados referentes aos metais $\mathrm{Cd}, \mathrm{Cr}, \mathrm{Ni}$ e $\mathrm{Pb}$ na parte aérea das plantas de milho não serão apresentados, tendo em vista que suas concentrações estiveram abaixo do limite de determinação do método analítico empregado. Oliveira (2000), avaliando a possibilidade de incrementos de metais pesados pelas plantas de cana-de-açúcar cultivadas em Latossolo Vermelho-Amarelo tratadas com 33, 66 e $99 \mathrm{Mg} \mathrm{ha}^{-1}$ (base seca) de lodo no primeiro ano e 37,74 e $110 \mathrm{Mg} \mathrm{ha}^{-1}$ (base seca) no segundo ano, também verificou que os possíveis incrementos de $\mathrm{Cd}, \mathrm{Cr}, \mathrm{Ni}$ e $\mathrm{Pb}$ nas plantas se apresentaram abaixo do limite de determinação do método utilizado.

Observou-se efeito significativo da aplicação das doses de lodo de esgoto no acúmulo de ferro, manganês e cobre pelas plantas e efeitos significativos da adubação com fósforo sobre o acúmulo de ferro e manganês (Apêndices 7e 8). A não verificação de interações entre os fatores dose de lodo, doses de fósforo e doses de potássio revela que a incorporação de lodo de esgoto no solo atua de forma predominante, no acúmulo de ferro, manganês e cobre pelas plantas.

Avaliando-se o comportamento do ferro e do cobre acumulado pelas plantas, através da análise de regressão, verifica-se que os dois metais apresentaram um comportamento linear crescente $\left(R^{2}=0,958\right.$ e $R^{2}=0,976$, respectivamente) com as doses do resíduo (Figuras 9 e 10). Os incrementos de ferro proporcionados pela adição do resíduo variaram, da menor para a maior dose aplicada, em relação a testemunha, de $18 \%$ a $159 \%$, respectivamente. Para o cobre a variação foi de $38 \%$ a $62 \%$, respectivamente.

Quanto ao manganês, a adição de doses crescentes de lodo promoveu um comportamento quadrático com tendência crescente $\left(\mathrm{R}^{2}=0,958\right)$ nas quantidades acumuladas pelas plantas (Figura 11). Os incrementos de manganês proporcionados pela adição do resíduo variaram, da menor para a maior dose aplicada, de $35 \%$ a $660 \%$, respectivamente. 


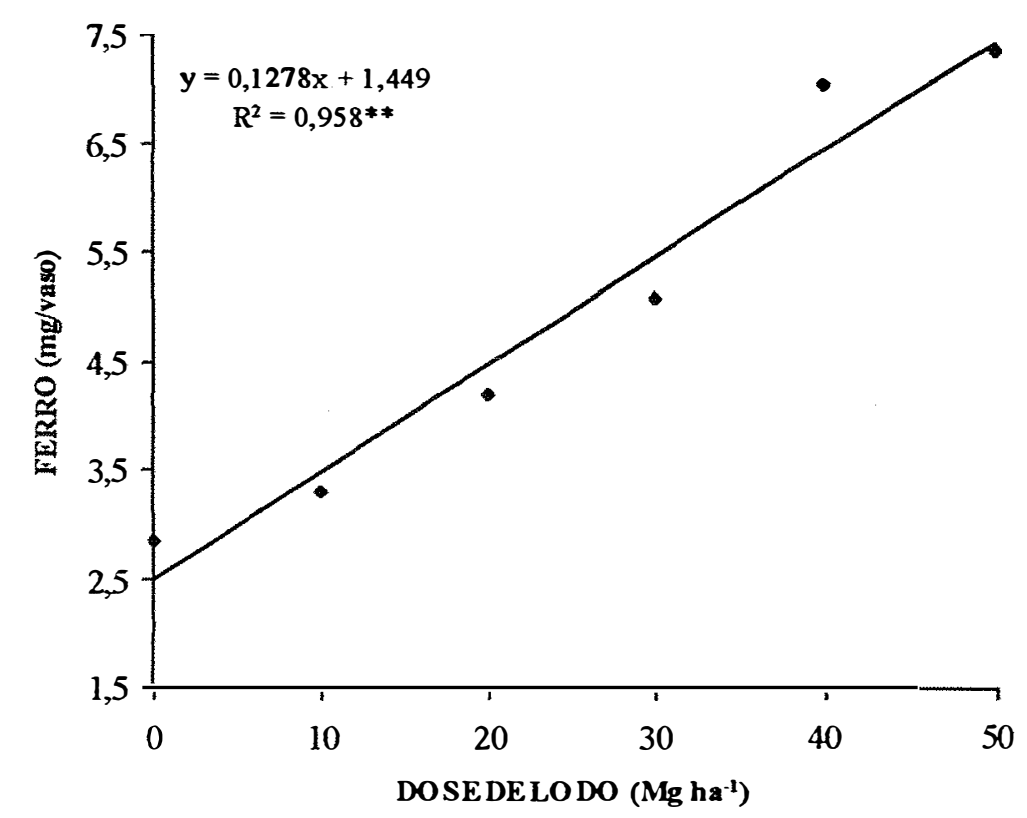

Figura 9. Ferro acumulado pela parte aérea das plantas em função da aplicação de doses de lodo

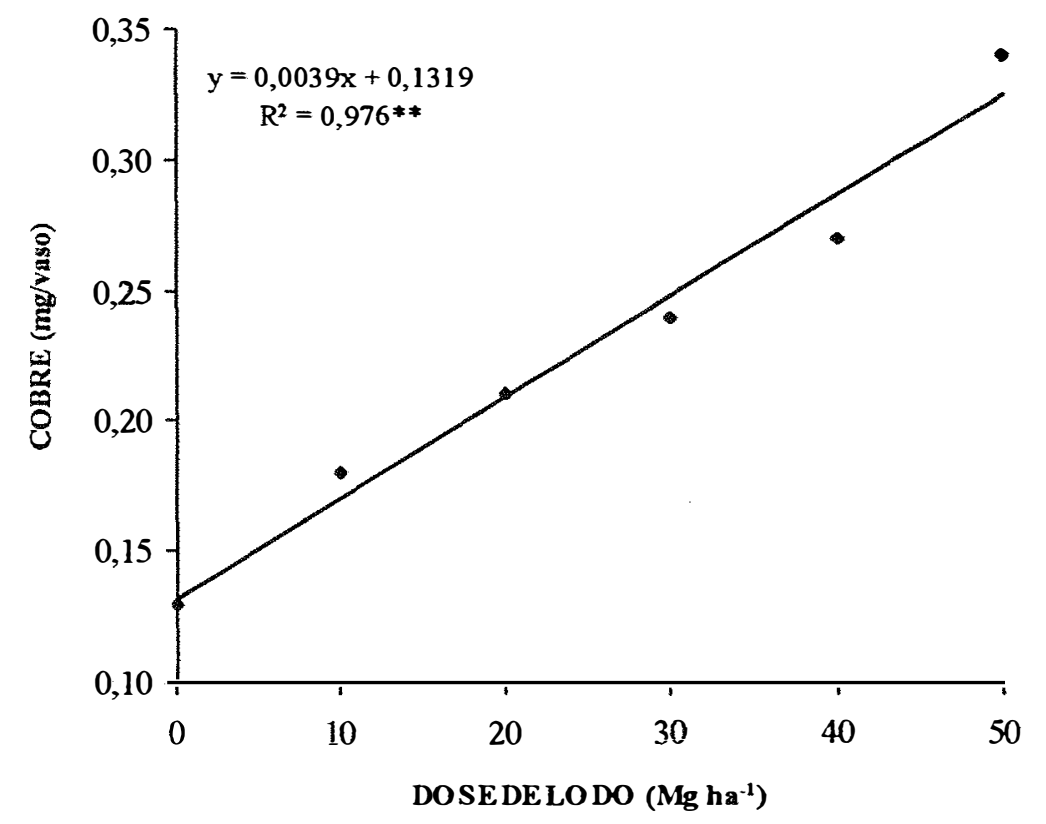

Figura 10. Cobre acumulado pela parte aérea das plantas em função da aplicação de doses de lodo 


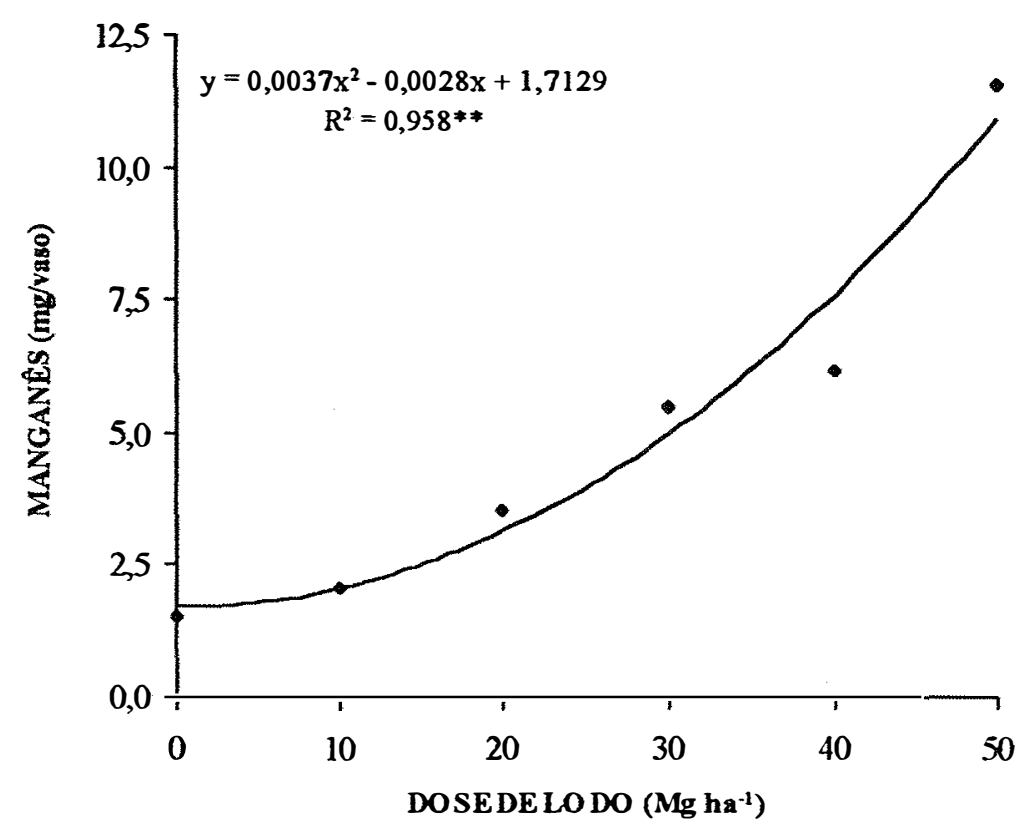

Figura 11. Manganês acumulado pela parte aérea das plantas em função da aplicação de doses de lodo

Para o zinco, houve efeito significativo da interação entre doses de lodo e de potássio mineral (Apêndice 9). A quantidade de zinco acumulada pelas plantas aumentou com a dose de lodo na presença ou ausência de potássio, de forma quadrática $\left(R^{2}=0,995\right.$ e $R^{2}=0,996$, respectivamente) (Figura 12). O acúmulo de zinco aumentou, da menor para a maior dose aplicada, de $18 \%$ a $159 \%$. Para o cobre, a variação foi de $38 \%$ a $62 \%$. Os tratamentos que receberam lodo com complementação potássica apresentaram menor acúmulo de zinco nas plantas em relação aos tratamentos que receberam apenas lodo. Isso poderia ser explicado em termos de adosorção. Shuman (1986) comenta que íons $\mathrm{Cl}^{-}$induzem a adsorção de $\mathrm{Zn}$, formando, provavelmente, um complexo estável com o zinco, principalmente a valores de $\mathrm{pH}$ mais baixos $(4-4,5)$. 


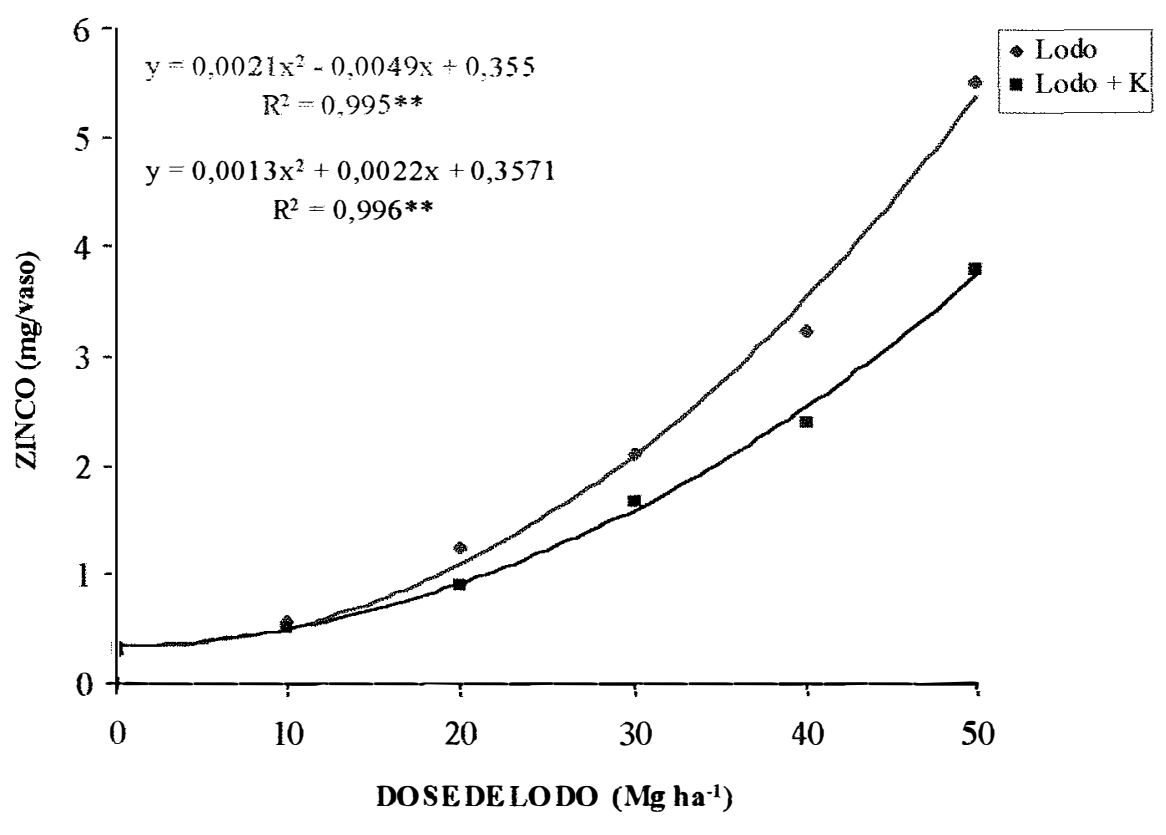

Figura 12. Zinco acumulado pela parte aérea das plantas em função da aplicação de doses de lodo, complementadas ou não com potássio

Quanto à adubação mineral, a adição de fósforo no solo na forma de super fosfato simples aumentou significativamente a quantidade acumulada de ferro (de 4,13 a $5,82 \mathrm{mg}$ de $\mathrm{P}$ por vaso) e manganês (de 4,14 a 6,04 $\mathrm{mg}$ de $\mathrm{P}$ por vaso). Esse fato pode ser explicado pela alta quantidade desses elementos presentes no adubo utilizado (Tabela 3).

Incrementos no acúmulo desses metais pelas plantas com a aplicação de lodo de esgoto eram esperados, uma vez que esses estavam presentes no resíduo (Tabela 4). Entretanto, há que se considerar que o solo apresentou decréscimo nos valores de pH (Figura 1). É sabido que a disponibilidade de metais é aumentada com a elevação da acidez do solo (Kabata-Pendias \& Pendias, 1984). Sendo assim, acredita-se que, principalmente para o manganês, onde as quantidade adicionadas foram relativamente baixas em relação aos demais metais, o aumento da acidez do solo exerce grande influência na disponibilidade do elemento para as plantas. Vários autores têm demonstrado que a adição de lodo de esgoto promove aumento na absorção de ferro, 
manganês, cobre e zinco pelas plantas (Mulchi et al.,1991; Berton et al., 1997; Anjos \& Mattiazzo (2000).

Os teores de $\mathrm{Fe}$ e $\mathrm{Cu}$ encontrados na parte aérea das plantas de todos os tratamentos encontram-se dentro dos intervalos considerados adequados para as plantas de milho, que são de $6-20 \mathrm{mg} \mathrm{kg}^{-1}$ e $50-250 \mathrm{mg} \mathrm{kg}{ }^{-1}$, respectivamente (Malavolta,1997 e Raij et al., 1996). Para o Mn e Zn, os teores obtidos para as duas maiores doses de lodo encontram-se acima da faixa $50-150 \mathrm{mg} \mathrm{kg}^{-1}$ e $15-50 \mathrm{mg} \mathrm{kg}^{-1}$, respectivamente, considerada adequada por Malavolta (1997). Isto sugere que as plantas cultivadas em solos tratados por vários anos, com lodo, poderão apresentar problemas relacionados com fitotoxicidade. Observações semelhantes também foram feitas por Oliveira (1995) e Anjos e Mattiazzo (2000).

Considerando-se as quantidades de metais adicionadas ao solo via lodo de esgoto (Tabela 4), percebe-se que as plantas removeram em média 0,3\%,0,9\% e $39 \%$ do total de ferro, cobre e manganês, respectivamente. Para o zinco, estas quantidades foram de $4 \%$ e $2,64 \%$, respectivamente para os tratamentos que receberam apenas lodo e nos tratamentos que receberam lodo com complementação com potássio. Entretanto, Chang et al. (1987) constataram que a absorção de metais pelas plantas, de maneira geral, é inferior a $1 \%$ da quantidade adicionada via lodo de esgoto.

\subsubsection{Fitodisponibilidade de metais}

A predição da fitodisponibilidade de metais às plantas de milho foi avaliada apenas para os metais $\mathrm{Fe}, \mathrm{Mn}, \mathrm{Cu}$ e $\mathrm{Zn}$, tendo em vista que os metais $\mathrm{Cd}, \mathrm{Cr}, \mathrm{Ni}$ e $\mathrm{Pb}$ não foram detectados nas amostras das plantas. Sendo assim, na Tabela 13 são apresentados os coeficientes de correlação linear simples obtidos entre teores e quantidades totais de $\mathrm{Fe}, \mathrm{Mn}, \mathrm{Cu}$ e $\mathrm{Zn}$ encontrados nas plantas e os teores desses elementos removidos pelos extratores, considerando os tratamentos que receberam doses de lodo de esgoto.

Verifica-se que todos os extratores foram eficientes na avaliação da disponibilidade de zinco para as plantas, considerando-se como índice a quantidade 
acumulada de metais pelas plantas. Para o manganês os extratores Mehlich-3 e $\mathrm{HCl} \mathrm{0,01}$ mol L ${ }^{-1}$ apresentaram maior índice de correlação na predição da fitodisponibilidade do que o DTPA. De forma concordante, Oliveira (2000), trabalhando em Latossolo Vermelho Escuto cultivado com cana-de-açúcar, tratado com doses de 33, 66 e $99 \mathrm{Mg}$ $\mathrm{ha}^{-1}$ (base seca) de lodo. no primeiro ano e 37, 74 e $110 \mathrm{Mg} \mathrm{ha}^{-1}$ (base seca) de lodo no

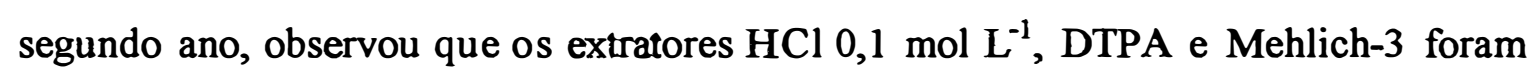
eficientes na avaliação da fitodisponibilidade de $\mathrm{Zn}$, quando considerado apenas os tratamentos que receberam doses de lodo.

Anjos (1999), avaliando a eficiência dos extratores $\mathrm{HCl} 0,1 \mathrm{~mol} \mathrm{~L}^{-1}$, Mehlich-3 e DTPA na fitodisponibilidade de metais para plantas de milho cultivadas em Latossolo Vermelho Escuro e Latossolo Roxo distrófico, que receberam doses sucessivas de lodo, que totalizaram 387,89 $\mathrm{Mg} \mathrm{ha}^{-1}$ (base seca), constatou que, dentre os extratores utilizados, o Mehlich-3 foi o mais eficiente na avaliação da disponibilidade de $\mathrm{Zn}$ para as plantas, nos dois solos. Porém nenhum extrator foi eficiente na avaliação da fitodisponibilidade de manganês.

Tabela 13. Coeficiente de correlação linear simples entre a quantidade total de metal absorvida pelas plantas e os teores removidos do solo pelos vários extratores, considerando os tratamentos que receberam doses de lodo

\begin{tabular}{|c|c|c|c|c|}
\hline Extrator & Ferro & Manganês & Cobre & Zinco \\
\hline & \multicolumn{4}{|c|}{ Quantidade total absorvida pelas plantas (mg vaso $\left.{ }^{-1}\right)$} \\
\hline $\mathrm{HCl} 0,1 \mathrm{~mol} \mathrm{~L}^{-1}$ & $0,42 * *$ & $0,81 * *$ & $0,48 * *$ & $0,86^{* *}$ \\
\hline Mehlich-3 & $0,38 * *$ & $0,82^{* *}$ & $0,46^{* *}$ & $0,87 * *$ \\
\hline DTPA & $0,35 * *$ & $0,65^{* *}$ & $0,54 * *$ & $0,89 * *$ \\
\hline
\end{tabular}

** Indica que as correlações foram significativas a $\mathrm{P} \leq 0,01$ pelo teste $\mathrm{t}$. 
Quanto ao ferro e cobre, apesar de todos os extratores terem apresentado correlações significativas, os índices obtidos através das correlações foram baixos, concluindo-se que todos os extratores se mostraram ineficientes na avaliação da fitodispobilidade desses metais. Entretanto, Oliveira (1995) ao correlacionar as quantidades de $\mathrm{Cu}$ absorvidas pelas plantas de milho com os teores removidos pelos extratores $\mathrm{HCl} 0,1 \mathrm{~mol} \mathrm{~L}^{-1}$ e DTPA, observou que ambos os extratores foram eficientes na avaliação da fitodisponibilidade de $\mathrm{Cu}$ em solos AQ e LR tratados com lodo. Mulchi et al. (1991) estudaram o efeito residual da aplicação de lodo de esgoto sobre a disponibilidade de metais para a cultura do fumo cultivada em solos franco siltoso e franco arenoso, que receberam, durante oito anos, doses de $0,56,112$ e $224 \mathrm{Mg} \mathrm{ha}^{-1}$ (base seca). Os autores verificaram que, dos extratores avaliados (Mehlich-1, Mehlich-3 e DTPA) nenhum extrator se mostrou eficiente para o Fe.

\section{3 Produção de matéria seca e acúmulo de macronutrientes}

\subsubsection{Produção de Matéria Seca}

Houve efeito significativo das interações entre os fatores doses de lodo e doses de potássio e entre a adubação mineral fosfatada e potássica na produção de matéria seca das plantas de milho, após 50 dias de crescimento (Apêndice 4).

Quando aplicada a regressão para a interação dos fatores dose de lodo e doses de potássio, tanto os tratamentos que receberam apenas lodo, quanto para os tratamentos que receberam lodo com complementação potássica, exibiram incrementos crescentes na produção de matéria seca com aumento das doses do resíduo. (Figura 13). Aumentos na produção de matéria seca em plantas de milho, com a aplicação de lodo de esgoto, também foram observados por Oliveira (1995), Pires (1998) e Souza et al. (1998).

A complementação do lodo com potássio mineral proporcionou maior produção de matéria seca das plantas em relação aos tratamentos que receberam apenas lodo. Esse fato era esperado, uma vez que tanto o solo quanto o lodo apresentavam baixo teor desse 
elemento $\left(1,8 \mathrm{mmol}_{\mathrm{c}} \mathrm{dm}^{-3}\right.$ e 1,3 $\mathrm{g} \mathrm{kg}^{-1}$, respectivamente). Efeitos significativos da complementação do lodo de esgoto com potássio sobre a produção de matéria seca do sorgo granífero foram observados por Oliveita et al. (1995).

Para a interação significativa entre fósforo e potássio mineral, verifica-se que quando foi aplicado fósforo na ausência de potássio ou potássio na ausência de fósforo, as plantas que receberam um dos dois elementos tiveram maior produção de matéria seca do que aqueles que não receberam adubação mineral. Com a aplicação de fósforo + potássio a produção de matéria seca foi superior à das plantas que receberam apenas fósforo ou potássio isoladamente (Tabela 14). Isto comprova que o solo estava deficiente nestes nutrientes.

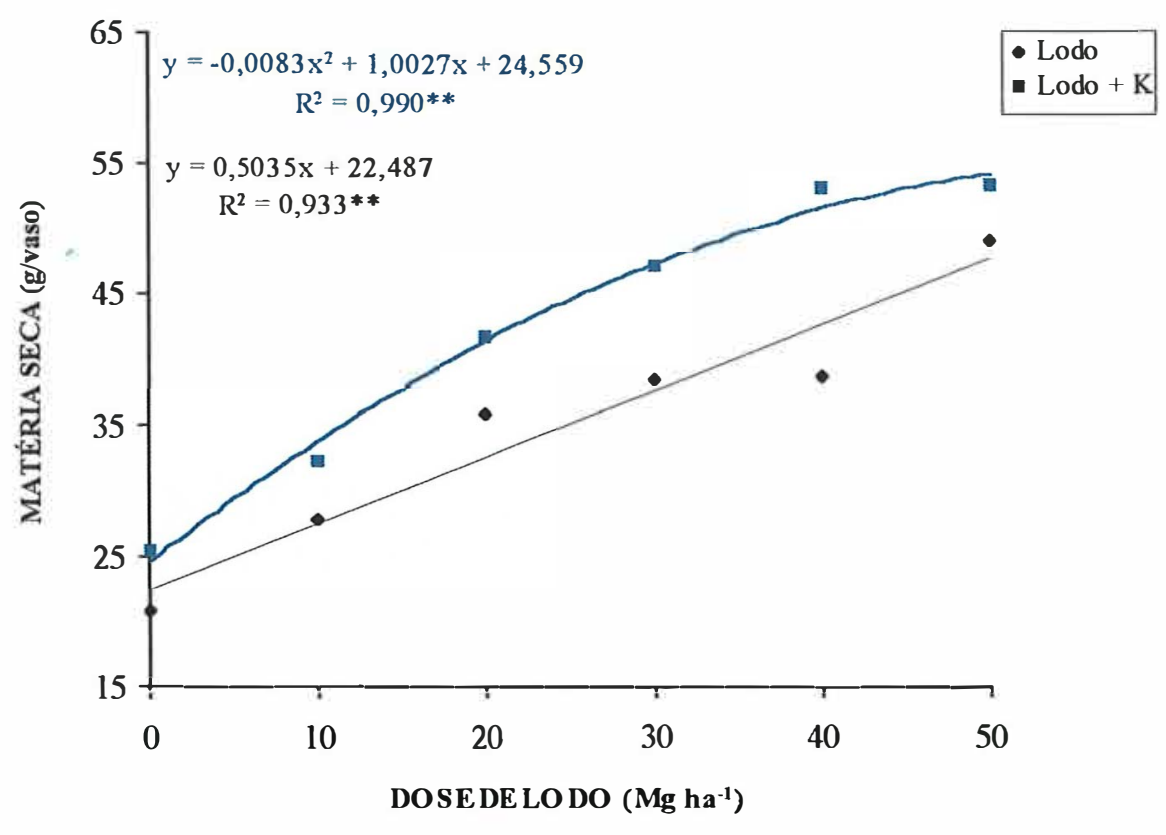

Figura 13. Produção de matéria seca da parte aérea das plantas de milho, em função da aplicação de doses de lodo complementadas ou não com potássio

Confrontando-se os resultados obtidos para matéria seca no tratamento que recebeu $50 \mathrm{Mg} \mathrm{ha}^{-1}$ de lodo complementado com potássio (Figura 13) com o tratamento 
que recebeu apenas fósforo + potássio mineral (Tabela 14), constata-se que ambos os tratamentos proporcionaram, praticamente, a mesma produção de matéria seca da parte aérea das plantas. De forma concordante, Oliveira et al. (1995) observaram que a adição de $20 \mathrm{Mg} \mathrm{ha}^{-1}$ (base seca) de lodo de esgoto, complementada com potássio mineral, proporcionou produção de matéria seca das plantas de sorgo granífero comparável à obtida com fertilização mineral recomendada.

Tabela 14. Produção de matéria seca da parte aérea das plantas, em função da adição de fósforo e potássio mineral

\begin{tabular}{|c|c|c|}
\hline Dose & \multicolumn{2}{|c|}{ Potássio ( $\left.\mathrm{mg} \mathrm{kg}^{-1}\right)$} \\
\hline Fósforo (mg kg $\left.{ }^{-1}\right)$ & 0 & 100 \\
\hline & $=$ & \\
\hline 0 & 26,64 B b & $30,40 \mathrm{~A} \mathrm{~b}$ \\
\hline 100 & $43,51 \mathrm{~B} \mathrm{a}$ & $53,71 \mathrm{~A} \mathrm{a}$ \\
\hline
\end{tabular}

Médias seguidas por letras maiúsculas distintas na horizontal diferem entre si pelo teste de Tukey ao nível de $5 \%$.

Médias seguidas por letras minúsculas distintas na vertical diferem entre si pelo teste de Tukey ao nível de $5 \%$.

Diante dos resultados encontrados para a produção de matéria seca, pode-se inferir que a não significância da interação doses de lodo x $\mathrm{P}$ mineral, deve-se ao suprimento deste nutriente em quantidades adequadas via lodo de esgoto. Isto também pode ser comprovado verificando-se as interações doses de lodo x K (Figura 13) e P x K (Tabela 14), onde em ambos os casos houve efeito do potássio, podendo-se concluir que o efeito do lodo está ligado ao suprimento do fósforo para as plantas. Entretanto, Anjos (1999), cultivando plantas de milho em dois solos, nos quais foram adicionados $4 \mathrm{Mg}$ $\mathrm{ha}^{-1}$ de fósforo via lodo de esgoto, verificou que as plantas apresentaram sintomas visuais de deficiências desse nutriente, o que foi corrigido com adubação mineral. Por 
outro lado, esses resultados concordam com Buting (1963) que afirma que os teores de fósforo contidos no lodo são adequados para as necessidades das plantas.

\subsection{Acúmulo de macronutrientes}

\subsubsection{Nitrogênio}

Através da análise de variância (Teste F) para o nitrogênio acumulado pelas plantas, verificou-se que houve interação significativa entre os fatores doses de lodo, doses de potássio e doses de fósforo (Apêndice 4).

Convém ressaltar que houve necessidade de adubar as plantas com nitrogênio devido à constatação de sintomas de deficiência deste nutriente, apesar de terem sido adicionadas, via lodo de esgoto, quantidades equivalentes a 470, 9101400,1870 e 2340 $\mathrm{kg} \mathrm{ha}^{-1}$ de $\mathrm{N}$, para as doses de $10,20,30,40$ e $50 \mathrm{Mg} \mathrm{ha}^{-1}$ de lodo, respectivamente. Silva (1995) e Anjos (2000) também verificaram que, quando foram adicionadas apenas doses de lodo de esgoto no solo, apareceram sintomas de deficiência do nutriente para as plantas de cana-de-açúcar e milho, respectivamente. $O$ primeiro autor associou esse fato a possível imobilização do nitrogênio nativo do solo na fase inicial de mineralização do lodo recém adicionado. Entretanto, Anjos (2000) cultivou plantas de milho após dois meses da última aplicação do resíduo. Isto revela que a taxa de mineralização do nitrogênio orgânico é um assunto que ainda necessita de estudos.

Observando-se as regressões para doses, verifica-se que, apesar da necessidade de aplicação de nitrogênio durante o desenvolvimento das plantas, tanto os tratamentos que receberam apenas lodo, quanto os que receberam complementação com potássio ou fósforo e fósforo com potássio, a adição de doses de lodo promoveu incrementos significativos na quantidade de nitrogênio acumulado pelas plantas. De forma concordante, Berton et al. (1989) e Oliveira et. al. (1995) demonstraram que a aplicação de lodo de esgoto promoveu incrementos de nitrogênio nas plantas. 


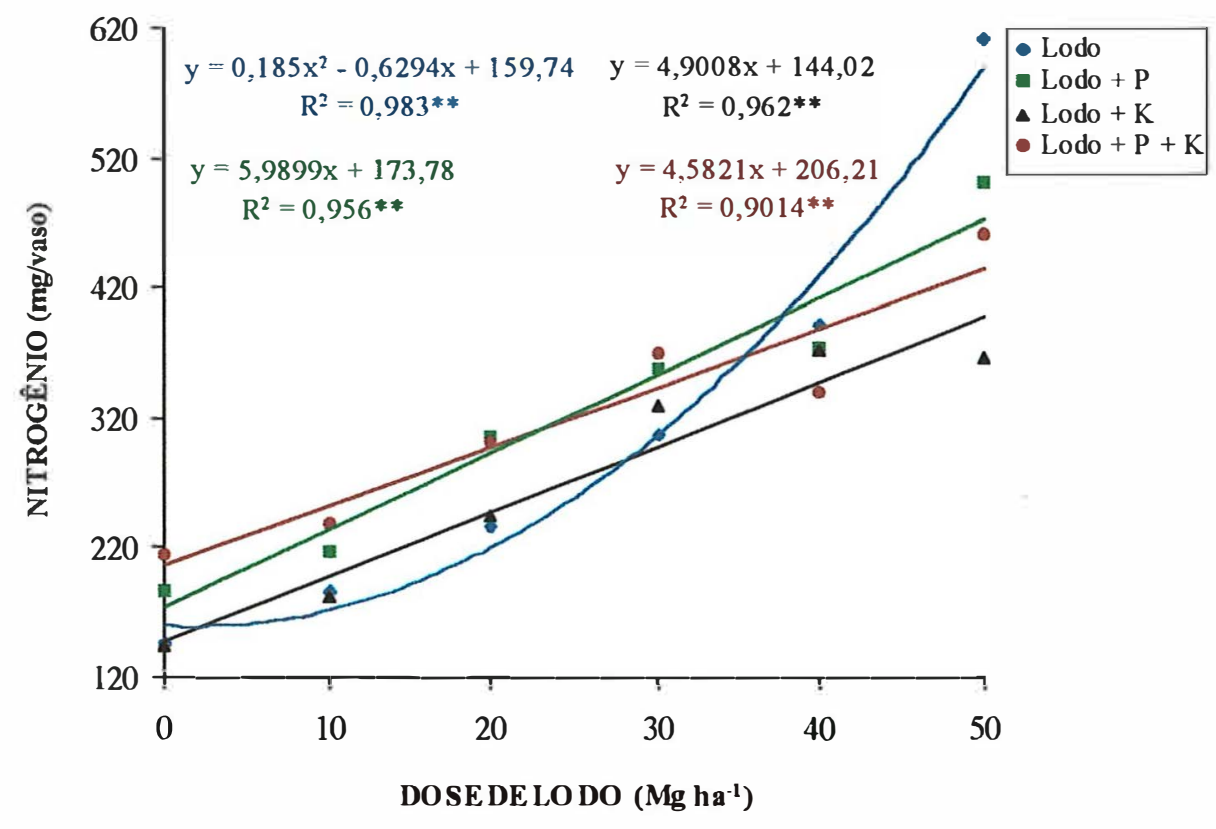

Figura 14. Nitrogênio acumulado pela parte aérea das plantas em função da aplicação de doses de lodo, complementadas ou não com potássio mineral

\subsubsection{Fósforo}

No acúmulo de fósforo pelas plantas, houve interação significativa entre a aplicação de doses de lodo e a adição de potássio mineral e efeito significativo da adubação mineral fosfatada (Apêndice 5).

A adição de lodo aumentou de $35 \%$ a $226 \%$ o acúmulo de fósforo nas plantas, dependendo da dose desse resíduo. Para as doses de lodo complementadas com potássio, os aumentos variaram de $29 \%$ a $133 \%$. A Figura 15 mostra que, em ambos os casos, esses aumentos foram lineares, o que vem confirmar os maiores teores de fósforo no solo com a aplicação das doses do lodo (Figura 2). Da mesma forma, Berton et al. (1989) verificou que a adição de 0, 40 e $80 \mathrm{Mg} \mathrm{ha}^{-1}$ (base seca), promoveu aumentos significativos nas quantidades de fósforo acumulado em plantas de milho cultivadas em cinco solos paulistas. 
A complementação das doses de lodo de esgoto com potássio mineral praticamente não afetou o acúmulo de fósforo pelas plantas, exceção apenas para a maior dose de lodo, onde a adição de apenas lodo de esgoto favoreceu maior acúmulo de fósforo pelas plantas em relação ao tratamento que recebeu complementação com potássio mineral. Isto poderia ser explicado por uma possível ocorrência de desbalanço nutricional no solo devido à elevada quantidade de potássio presente neste tratamento.

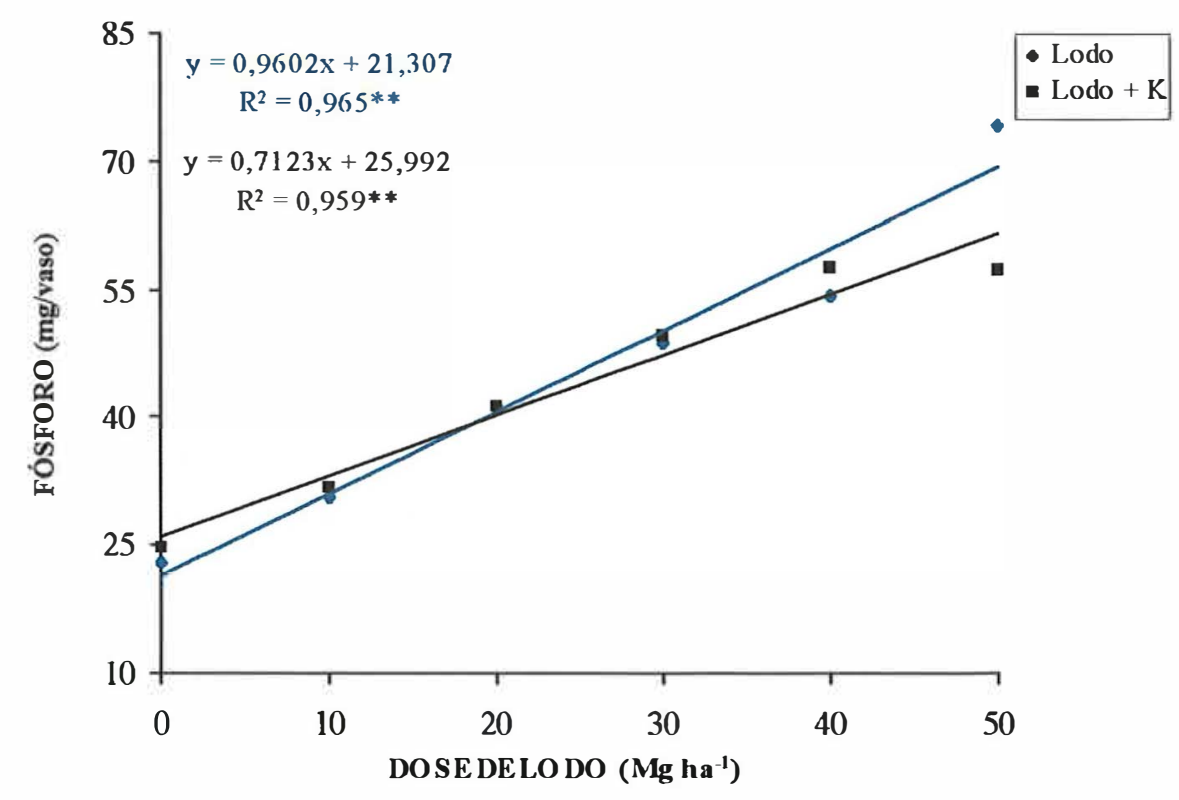

Figura 15. Quantidade de fósforo acumulada na parte aérea das plantas em função da aplicação de doses de lodo, complementadas ou não com potássio mineral

Quanto aos tratamentos que receberam apenas adubação mineral, observou-se que a adubação fosfatada aumentou significativamente o acúmulo de fósforo nas plantas, de 29,9 para 60,02 g por vaso, indicando que o solo estava deficiente neste nutriente. Como não houve interação entre os fatores $\mathrm{P} \times \mathrm{K}$ mineral, conclui-se que o potássio não exerceu influência no aumento do acúmulo de fósforo pelas plantas. 
A não verificação da interação entre os fatores doses de lodo e complementação com fósforo mineral, aliada ao fato de que nos tratamentos que receberam somente adubação fosfatada houve aumentos significativos no acúmulo do fósforo, e também ao fato de que a interação lodo x K mineral foi significativa (Figura 15), sugere que o lodo de esgoto foi suficiente para atender a exigência de fósforo pelas plantas.

\subsubsection{Enxofre}

Houve interações significativas entre doses de lodo e doses de potássio e entre a aplicação de fósforo e potássio mineral no acúmulo de enxofre $\left(\mathrm{S}_{-} \mathrm{SO}_{4}\right)$ pela parte aérea das plantas (Apêndice 5).

As regressões para doses de lodo e doses de lodo complementadas com potássio, mostraram que, em ambos os casos, o acúmulo de enxofre pelas plantas aumentou linearmente com as doses do resíduo (Figura 16). Observando-se o comportamento desse nutriente no solo, avaliado após 30 dias de incubação (Figura 2), verifica-se que os teores diminuíram de forma quadrática com o aumento das doses do resíduo, o que foi justificado pela redução da mineralização da matéria orgânica. Como a quantidade de enxofre acumulada pelas plantas aumentou de forma linear, pode-se inferir que ocorreu mineralização da matéria orgânica durante o período de desenvolvimento das plantas, com conseqüente liberação de enxofre. Incrementos de enxofre nas plantas, em função da aplicação de lodo de esgoto ao solo, também foram observados por Pereira Junior et al. (1997) e Silva et al. (1998).

No tratamento lodo mais complementação potássica, o acúmulo de enxofre pelas plantas foi menor que no tratamento que recebeu apenas lodo de esgoto. Isto pode ter ocorrido devido à aplicação de potássio na forma de cloreto de potássio. Segundo Malavolta et al. (1997), elevados teores do cloro $\left(\mathrm{Cl}^{-}\right)$na solução do solo podem inibir competitivamente a absorção de sulfato pelas plantas, uma vez que estes concorrem pelo mesmos sítio de absorção das raízes das plantas. 


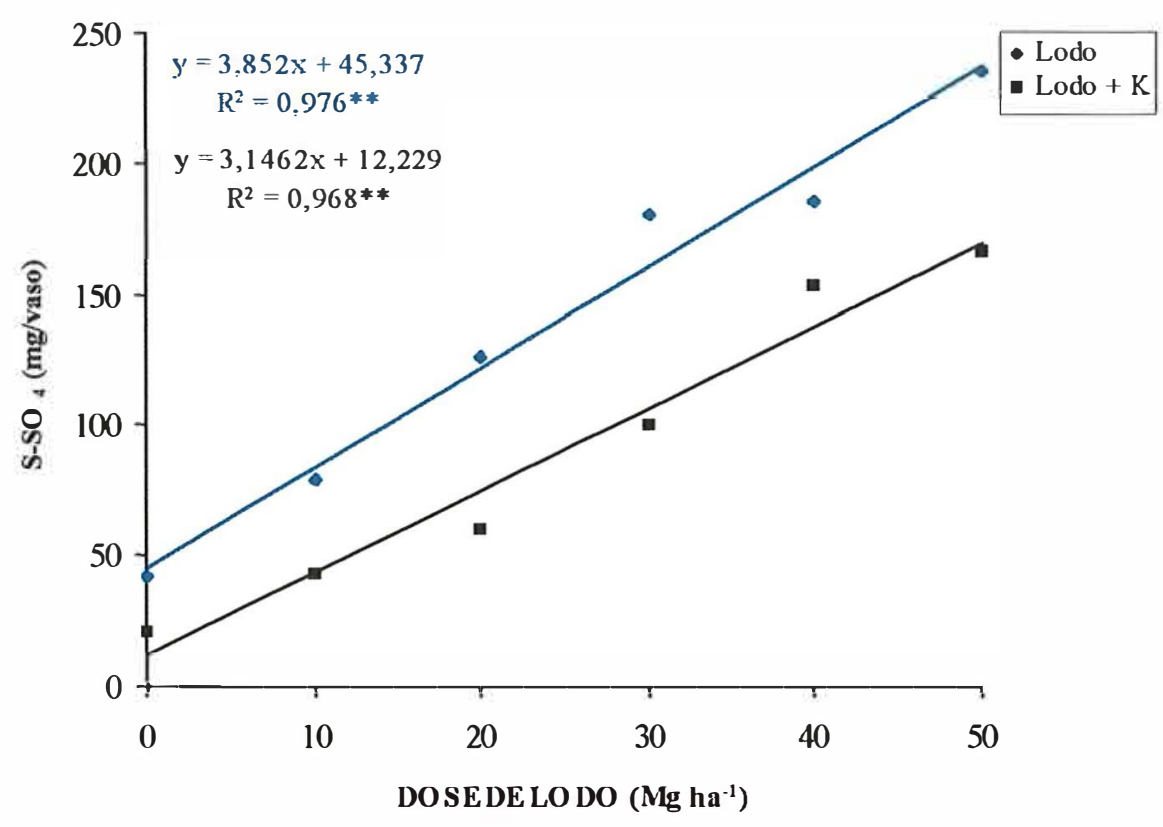

Figura 16. Quantidade de enxofre $\left(\mathrm{S}^{-} \mathrm{SO}_{4}\right)$ acumulado na parte aérea das plantas em função da aplicação de doses de lodo, complementadas ou não com potássio mineral

$\mathrm{Na}$ interação entre fósforo e potássio mineral (Tabela 15), verifica-se que, quando se adiciona fósforo na ausência de potássio e fósforo no tratamento que recebeu potássio, ocorre aumento significativo no acúmulo de enxofre pelas plantas. Entretanto, quando se adiciona potássio na ausência de fósforo e potássio no tratamento que recebeu fósforo ocorre redução significativa no acúmulo de enxofre, comprovando que a adição de potássio no solo, na forma de cloreto de potássio, promoveu redução no acúmulo de enxofre pelas plantas. 
Tabela 15. Quantidade de enxofre $\left(\mathrm{SO}_{4}{ }^{-2}\right)$ acumulado nas plantas em função da adubação mineral fosfatada e potássica

\begin{tabular}{ccc}
\hline Dose & \multicolumn{2}{c}{ Potássio $\left(\mathrm{mg} \mathrm{kg}^{-1}\right)$} \\
\cline { 2 - 3 } Fósforo $\left(\mathrm{mg} \mathrm{kg}^{-1}\right)$ & 0 & 100 \\
\hline & \multicolumn{1}{c}{ Enxofre acumulado $(\mathrm{mg} / \mathrm{vaso})$} & \\
0 & $112,08 \mathrm{~A} \mathrm{~b}$ & $76,44 \mathrm{~B} \mathrm{~b}$ \\
200 & $171,19 \mathrm{~A} \mathrm{a}$ & $105,32 \mathrm{~B} \mathrm{a}$
\end{tabular}

Médias seguidas por letras maiúsculas distintas na horizontal diferem entre si pelo teste de Tukey ao nível de $5 \%$.

Médias seguidas por letras minúsculas distintas na vertical diferem entre si pelo teste de Tukey ao nivel de $5 \%$.

\subsubsection{Potássio}

Para o potássio acumulado pela parte aérea das plantas, constatou-se interação significativa entre os fatores doses de lodo, doses de potássio e doses de fósforo (Apêndice 6).

Observando-se as regressões para as doses (Figura 17), verifica-se claramente a contribuição da complementação com potássio no acúmulo do elemento pelas plantas. A resposta à adubação com potássio vem a confirmar o baixo incremento do potássio observado no solo com a aplicação das doses do lodo (Figura 3). De forma concordante, Giordano \& Mays (1981) afirmam que o lodo de esgoto não é uma boa fonte de potássio para as plantas. A pequena contribuição do lodo no fornecimento de potássio para as culturas em trabalhos com menores taxas de aplicação, tem sido relatado por vários autores. Como exemplo pode-se citar os trabalhos de Oliveira et al. (1995) com a cultura do sorgo granifero, Ros et al. (1993) com aveia e ervilhaca e Marques (1990) com a cana-de-açúcar.

Embora as plantas tenham apresentado aumento no acúmulo de potássio na parte aérea nos tratamentos que receberam doses de lodo complementadas com $\mathrm{P}+\mathrm{K}$ mineral, 
verificou-se que esses incrementos não responderam em produção de matéria seca, uma vez que esta foi influenciada apenas pela complementação do lodo com potássio (Figura 13). É característica do potássio ser acumulado pelas plantas em quantidades acima das necessárias, desde que os níveis no solo sejam altos, originando o consagrado conceito de "consumo de luxo" (Mengel \& Kirkby, 1982).

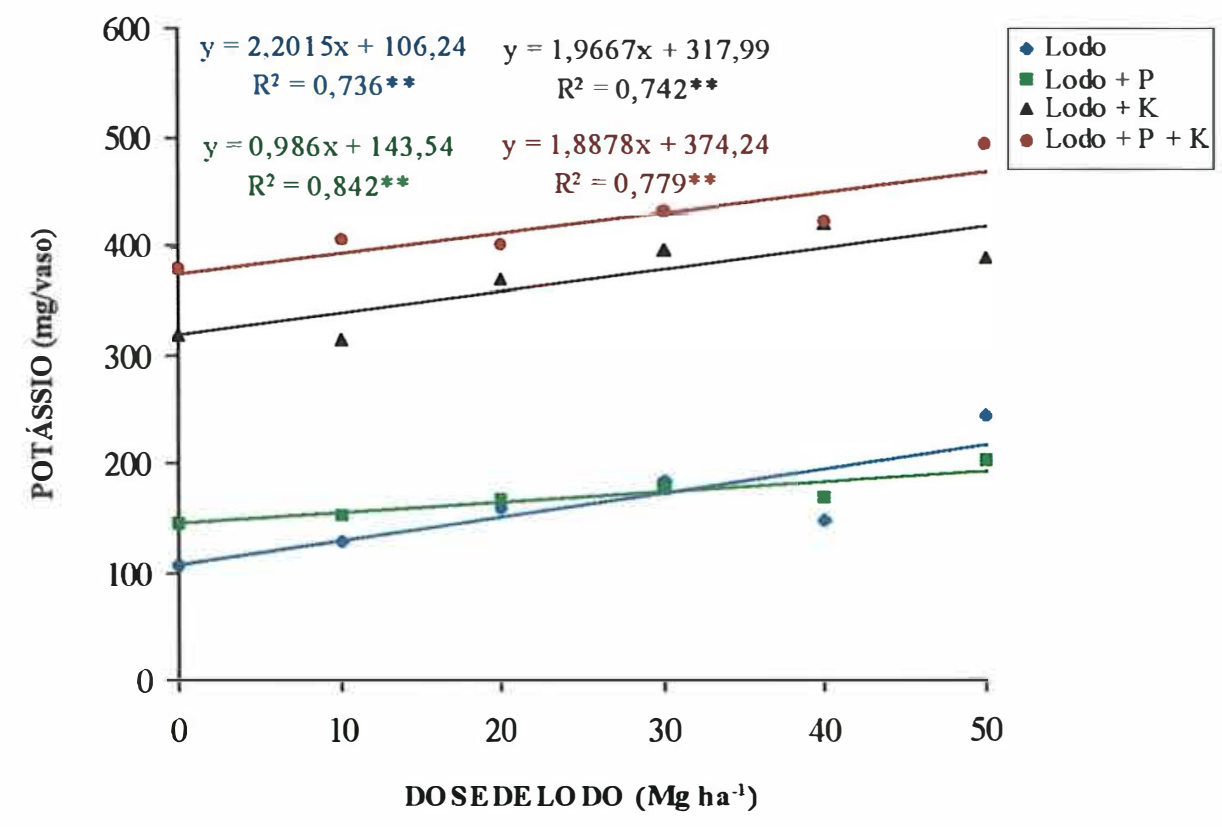

Figura 17. Potássio acumulado na parte aérea das plantas em função da aplicação de doses de lodo, complementadas ou não com potássio mineral

\subsubsection{Cálcio e Magnésio}

Houve interação significativa entre as doses de lodo e as doses de potássio mineral no acúmulo de cálcio e magnésio da parte aérea das plantas, e efeito significativo da aplicação de fósforo no solo sobre o acúmulo destes elementos pelas plantas (Apêndices 6 e 7). 
Através da regressão para as doses de lodo, complementadas ou não com potássio, observa-se que a aplicação as dose de lodo de esgoto aumentou linearmente as quantidades de cálcio e magnésio acumuladas pelas plantas (Figuras 18 e 19). Isto confirma o aumento dos teores disponíveis desses elementos no solo com a adição do resíduo (Figura 3). Incrementos no acúmulo de cálcio e magnésio pelas plantas com a aplicação de lodo de esgoto têm sido demostrados por vários autores (Berton, 1989; Oliveira et al. 1995; Marques, 1996).

A complementação do lodo de esgoto com potássio diminuiu o acúmulo de cálcio e magnésio nas plantas. Segundo Malavolta et al. (1997), elevadas concentrações de potássio na solução do solo podem inibir competitivamente a absorção de cálcio e, principalmente, a de magnésio pelas raizes das plantas. Aliado a este fato, Barber (1984) relata que, quando o potássio é empregado em uma cultura que responde a ele, o teor de magnésio no tecido da planta freqüentemente diminui.

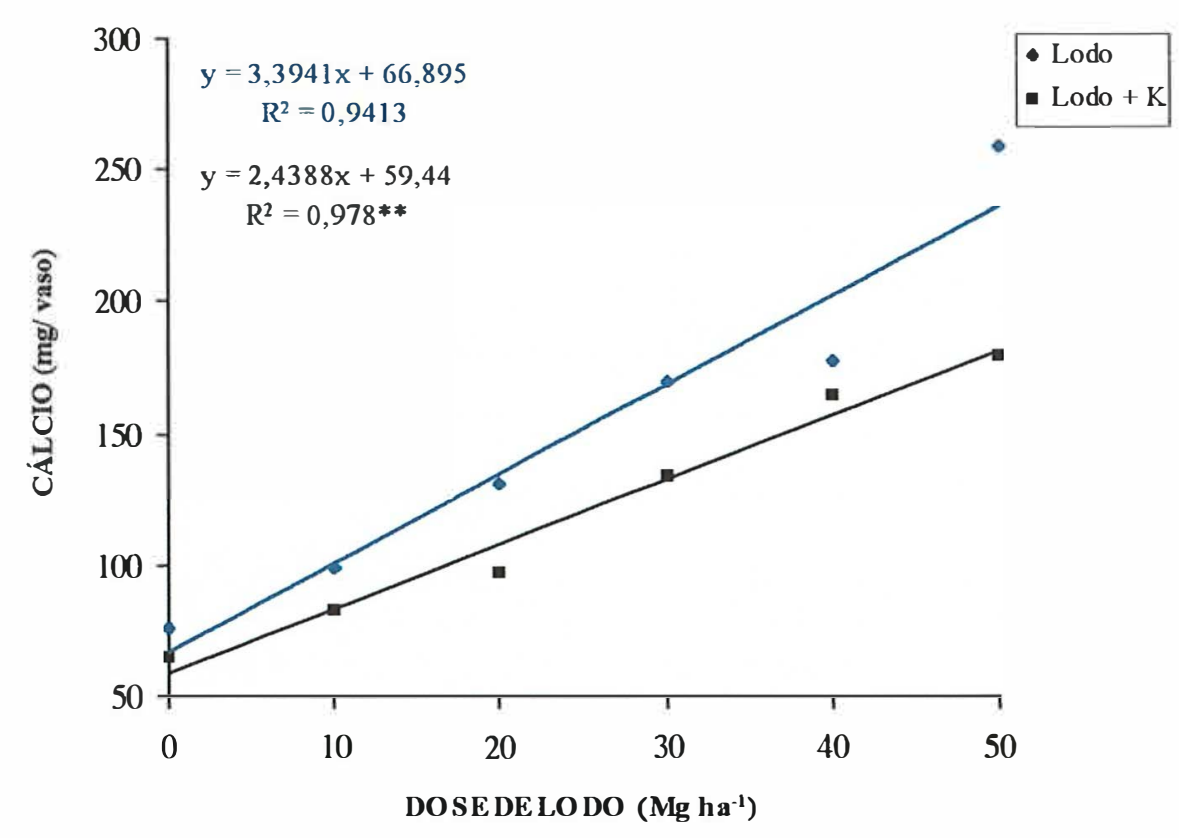

Figura 18. Quantidade de cálcio acumulado pela parte aérea das plantas em função da aplicação de doses de lodo, complementadas ou não com potássio 


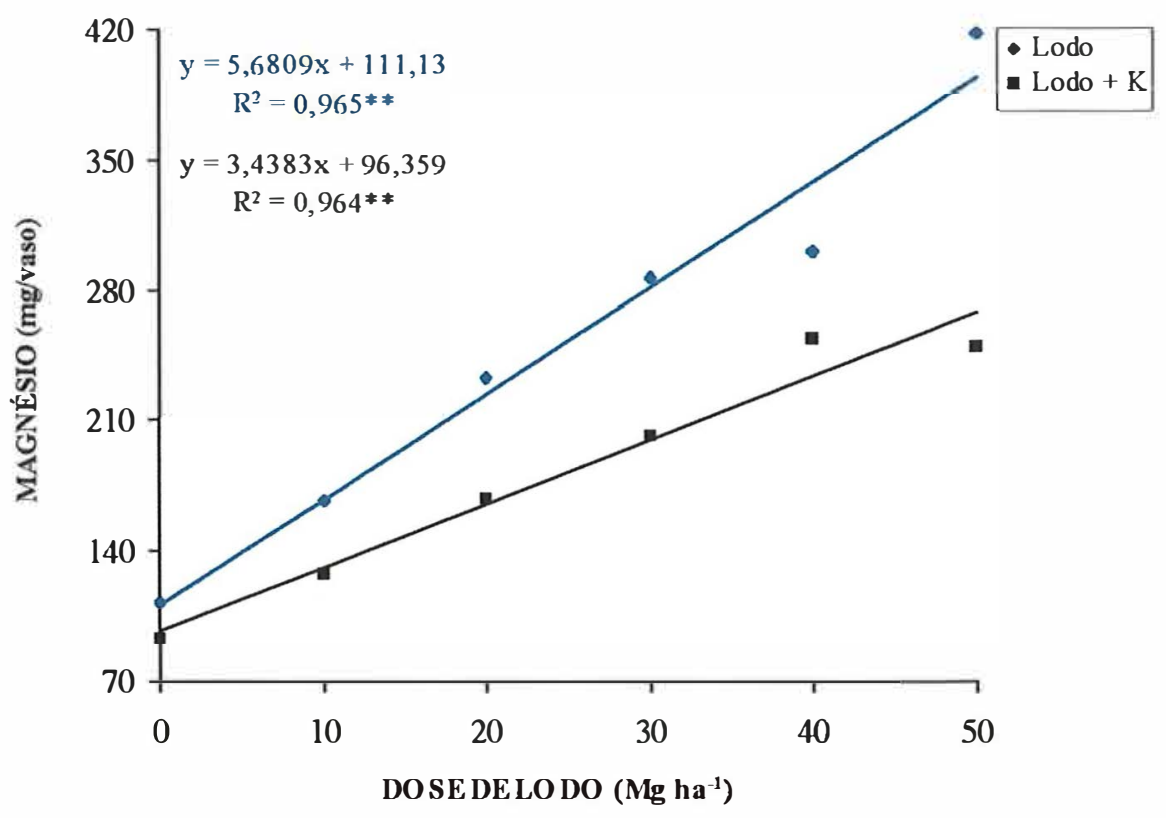

Figura 19. Quantidade de magnésio acumulado pela parte aérea das plantas em função da aplicação de doses de lodo, complementadas ou não com potássio 


\section{CONCLUSÕES}

- A aplicação do lodo de esgoto no solo proporcionou redução do pH e aumento nos valores de $\mathrm{Al}$ trocável, $\mathrm{H}+\mathrm{Al}, \mathrm{m} \%$; $\mathrm{MO}, \mathrm{SB}, \mathrm{CTC}$ e os teores disponíveis de $\mathrm{P}$, $\mathrm{SO}_{4}, \mathrm{Ca}, \mathrm{Mg}, \mathrm{Fe}, \mathrm{Cu}, \mathrm{Mn}$.

- O lodo de esgoto aumentou o acúmulo de todos os macro e micronutrientes nas plantas de milho e a produção de matéria seca da parte aérea.

- A complementação do resíduo com potássio mineral aumentou a produção de matéria seca da parte aérea das plantas, porém, a complementação com fósforo não alterou a produção de matéria seca.

- As soluções ácidas $\left(\mathrm{HCl} 0,01 \mathrm{~mol} \mathrm{~L}^{-1}\right.$ e Mehlich-3) apresentaram maior capacidade de extração de $\mathrm{Fe}, \mathrm{Cu}, \mathrm{Mn}$ e $\mathrm{Zn}$ do que à solução de DTPA.

- Os extratores $\mathrm{HCl}$ 0,01 mol $\mathrm{L}^{-1}$, Mehlich-3 e DTPA foram eficientes para predição da fitodisponibilidade de $\mathrm{Zn}$. Para o $\mathrm{Mn}$, os mais eficientes foram o $\mathrm{HCl}$ $0,01 \mathrm{~mol} \mathrm{~L}^{-1}$ e Mehlich-3. 


\section{REFERÊNCIAS BIBLIOGRÁFICAS}

ABREU, C.A.; ABREU, M.F.; RAIJ, B. van.; SANTOS, W.R. Comparação de métodos de análises para avaliar a disponibilidade de metais pesados em solos. Revista Brasileira de Ciência do Solo, v.19, p.463-468, 1995.

ABREU, C.A.; ABREU, M.F.; SOARES, L.H.; ANDRADE, J.C. The effects of the DTPA extraction conditions on the determination of micronutrients in Brazilian soils. Communications of Soil Science and Plant Analysis, v.28, p.1-11, 1997.

ADRIANO, D.C. Trace elements in terrestrial environment. New YorK: SpinglerVerlag, 1986. 533p.

ANDERSON, N.S. Fertilizer characteristics of sewage sludge. Sewage Ind. Plants, v.31, p.678-682, 1959.

ANDRADE, C.A. Nitratos e metais pesados no solo e em plantas de Eucalyptus grandis após aplicação de biossólido da ETE de Barueri. Piracicaba, 1999. 65p. Tese (Mestrado) - Escola Superior de Agricultura "Luiz de Queiroz", Universidade de São Paulo.

ANJOS, A.R.M.. Lixiviação de espécies químicas em latossolos sucessivamente tratados com biossólido e disponibilidade de metais pesados para plantas de milho. Piracicaba, 1999. 191p. Tese (Doutorado) - Escola Superior de Agricultura "Luiz de Queiroz", Universidade de São Paulo.

ANJOS, A.R.M.; MATTIAZZO, M.E. Metais pesados em plantas de milho cultivadas em Latossolos repetidamente tratados com biossólido. Scientia Agricola, v.37, n.4, p.769-776, 2000. 
AYUSO, M.; HERNANDEZ, T.; GARCIA, C.; COSTA, F. Utilización d'un lodo aerobio como sustitutivo de fertilizantes fosforados inorgánicos. Suelo y Planta, v.2, p.271-280, 1992.

BARBER, S. Soil Nutrient Bioavailability: Amechanistic Approach. New York: John Wiley \& Son, 1984. 398p.

BARRETO, M.C.V. Degradação da carga orgânica de diferentes resíduos e seus respectivos efeitos em alguns atributos químicos e físicos do solo. Piracicaba, 1995. 106p. Tese (Doutorado) - Escola Superior de Agricultura "Luiz de Queiroz", Universidade de São Paulo.

BERTON, S.B. Riscos de contaminação do agrossistema com metais pesados. In: BETTIOL, W.; CAMARGO, O.A. Impacto ambiental do uso do lodo de esgoto. Jaguariuna: EMBRAPA Meio Ambiente, 2000, p.259-268.

BERTON, R.S.; CAMARGO, O.A.; VALADARES, J.M.A.S. Absorção de nutrientes pelo milho em resposta à adição de lodo de esgoto a cinco solos paulistas. Revista Brasileira de Ciência do Solo, v.13, n.2, p.187-192, 1989.

BERTON, R.S.; VALADARES, J.M.A.S.; CAMARGO, O.A.; BATAGLIA, O.C. Peletização do lodo de esgoto e adição de $\mathrm{CaCO}_{3}$ na produção de matéria seca e absorção de $\mathrm{Zn}, \mathrm{Cu}$, e $\mathrm{Ni}$ pelo milho em três latossolos. Revista Brasileira de Ciência do Solo, v.21, n.4, p.685-691, 1997.

BERTONCINI, E.I. Mobilidade de metais pesados em solos tratados com lodo de esgoto. Piracicaba, 1997. 90p. Dissertação (Mestrado) - Escola Superior de Agricultura "Luiz de Queiroz", Universidade de São Paulo. 
BERTONCINI, E.I.; MATTIAZZO, M.E. Lixiviação de metais pesados em solos tratados com lodo de esgoto. Revista Brasileira de Ciência do Solo, v.23, n.3, p.737-744, 1999.

BIDWELL, A. M.; DOWDY, R.H. Cadmium and zinc availability to com following termination of sewage sludge applications. Journal of Environmental Quality, v.16, n.4, p.438-442, 1987.

BISCAIA, R.C.M.; MIRANDA, G.M. Uso do lodo de esgoto calado na produção de milho. Sanare, v.5, n.5, p.86-89, 1996.

BITTELL, J.E.; MILLER, R.J. Lead, cadmium and calcium selectivity coefficients on a montmorillonite, illite and kaolinite. Journal of Environmental Quality, v.3, n.3, p.250-253, 1974.

BORKERT, C.M. Manganês. In: SIMPÓSIO SOBRES MICRONUTRIENTES NA AGRICULTURA, 1., Jaboticabal, 1988. Anais. Piracicaba: POTAFOS/CNPq, 1991. p.173-190.

BRASIL, Ministério da Agricultura. Inspeção e fiscalização da produção e do comércio de fertilizantes, corretivos, inoculantes e biofertilizantes destinados à agricultura - Legislação e fiscalização. Brasília: Secretaria Nacional de Defesa Agropecuária, Divisào de Corretivos e Fertilizantes, 1982. 88p.

BUTING, A.H. Experiments on organic manures. Journal Agriculture Science, v.60, p.121-140, 1963.

CAMARGO, O.A.; MONIZ, A.C.; JORGE, J.A.; VALADARES, J.M.A.S. Métodos de análise química, mineralógica e física de solos do Instituto Agron6omico de Campinas. Campinas: IAC, 1986. 94p. (IAC. Boletim Técnico, 106) 
CANELLAS, L.P.; SANTOS, G.A.; BRASLL SOBRINHO, N.M. Reações da matéria orgânica do solo. In: SANTOS, G.A.; CAMARGO, F.A.O. (Eds) Fundamentos da matéria orgânica do solo: ecossistemas tropicais e subtropicais. Porto Alegre: Geneses, 1999, p.69-90.

CANTARELlA, H.; RAIJ, B. van.; QUAGGIO, J.A. Situação da análise de solo e planta no Brasil. In: REUNIÃO BRASLEIRA DE FERTILIDADE DO SOLO E NUTRIÇÃO DE PLANTAS, 21., Petrolina, 1994. Fertilizantes: insumo básico para agricultura e combate à fome; Anais. EMBRAPA-CPATSA-SBCS, 1995. p.9-33.

CARVALHO, P.C.T.; BARRAL, M.F. Aplicação de lodo de esgoto como fertilizante. Fertilantes, v.3, n.2, p.1-4, 1981.

CAST - Council for Agricultural Science and Technology. Aplication of sewage to croplano: appraisal of potential hazards of the heavy metais to plants and animais. Ames. IA., 1976. 77p. (Report, n.64)

CAST - Council for Agricultural Science and Technology. Organic anda conventional forming compared. Illinois, 1980. 32p. (Report, n.84)

CAVALlARO, N.; PADILLA, N. ; VILLARRUBIA, J. Sewege sludge effcts on chemical properties of acid soils. Soil Science, v.156, n.2, p.63-70, 1993.

CHANG, A.C.; HINESLY, T.D.; DONER, H.E.; DOWDY, R.H.; RYAN, J.A. Effects of long term sludge application on accumulation of trace elements by crops. In: PAGE, A.L.; LOGAN, T.J.; RYAN, J.A. Land application of sludge-food chain implications. Chelsea: Lewis Publisher, 1987. Cap.4, p.53-66. 
DIAS, F.L.F. Efeito da aplicação de calcário, lodo de esgoto e vinhaça em solo cultivado com sorgo granífero (Sorghum bicolor L.). Jaboticabal. 1994. 74p. Faculdade de Ciências Agrárias e Veterinárias, Universidade Estadual Paulista "Julio de Mesquita".

DOWDY, R.H.; LIBERATI, J.J.; HINESLY, T.D.; GROSSMAN, R.B.; SULLIVAN, D.L. Trace metal movement in a aeric ocharaqualf following 14 years of annual slude aplications. Journal of Environmental Quality, v.20, n. 1, p.119-123, 1991.

EGREJA FILHO, F.B. Avaliação da ocorrência e distribuição química de metais pesados na compostagem do lixo domiciliar urbano. Viçosa, 1993. 176p. (Dissertação) - Universidade Federal de Viçosa.

ELLIOT, H.A.; LIBERATTI, M.R.; HUANG, C.P. Effect of iron oxide removal on heavy metal sorption by acid subsoils. Water, Air, Soil, Pollution, v.37, p.379-389, 1986.

EMPRESA BRASILEIRA DE PESQUISA AGROPECUÁRIA. Manual de métodos de análise de solo 2. ed. Rio de Janeiro: EMBRAPA-CNPS, 1997. 212p.

FULLER, W.H.; WARRICK, A.W. Soils in waste treatment and utilization. Boca Ratoon: CRC Press, 1985. v.1, 268p.

GALLOWAY, H.M; JACOBS, L.W. Sewage slude. I. Caracteristics and management. Utilization municipal sewage was and sludges on land for agricultural production. In: NORTH CENTRAL REGIONAL EXTENSION PUBLICATION. Washington, D.C., 1977. p.3-17. 
GARCIA JUNIOR, O. O enxofre e suas transformações microbiológicas. In: CARDOSO, E.J.B.N.; TSAI, S.M.; NEVES, M.C.P (Ed.). Microbiologia do solo. Campinas: SBCS, 1992. Cap.22, p.319-340.

GIORDANO, P.M.; MAYS, D.A. Plant nutrientents municipal sewage sludes. Eng. Chem. Prod. Res. Dev., v.20, n.2, p.212-216, 1981.

HOODA, P.S.; ALLOWAY, B.J. The plant availability and DTPA extractability of trace metals in sludge-amended soils. The Science Total of the Environronment, v.149, p.39-51, 1993.

HOODA, P.S.; McNULTY, D; ALLOWAY, B.J; AITKEN, M.N. Plant availability of heavy metals in soils previously amended with heavy applications of sewage sludge. Journal Science Food Agriculture, v.73, p.446-454, 1997.

HUNGRIA, M.; URQUIAGA, S. Transformações microbianas de outros elementos (potássio, micronutrientes e metais pesados). In: CARDOSO, E.J.B.N.; TSAI, S.M.; NEVES, M.C. (Ed.) Microbiologia do solo. Campinas: SBCS, 1992. cap. 23, p.329-340.

KABATA-PENDIAS, A.: PENDIAS, H. Trace elements in soil and plants. Boca Raton: CRC Press, 1984. 315p.

KELLER, C.; VÉDY, J. C. Distribuition of copper and cadmium fractions in two forest soils. Journal of Environmental Quality, v.23, n.5, p.987-999, 1994.

KIEHL, E.J. Fertilizantes Orgânicos. Piracicaba: Ceres, 1985. 492p. 
KIM, S.J. CHANG, A.C.; PAGE, A.L.; WARNEKE, J.E. Relative concentrations of cadmium and zinc in tissue of selected food plants grown on sludge-treated soils. Journal of Environmental Quality, v. 17, n. 14, p.568-573, 1988.

KING, L.D.; HAJJAR, L.M. The residual effect of sewage sludge on heavy metal content of tabacco and peanut. Journal Environmental quality, v.19, p.738-748, 1990.

KLUTE, A. Water retention: Laboratory Methods. In: KLUTE, A. (Ed.), Methods of Soil Analysis: Physical and Mineralogical Methods, Chap. 26. American Society of Agronomy, Wisconsin- USA: Madison, 1986, 635-660p.

KOLTHOFF, J.M.; SADELL, E.B.; MEEHAN, E.J.; BRUCKENSTEIN, S. Quantitative Chemical Analysis. London: Macmillan, 1969. p.1199.

KORENTAJER, L. A review of the agricultural use of sewage sludge: benefits and potential hazards. Water A S, v.17, p.189-196, 1991.

LESCHBER, R.; DAVIES, R.D; L'HERMITE, P. Chemical methods for assessing bioavailability metals in sludge and soils. London, Elsevier, 1985. 96p.

LINDEN, D.R.; CLAPP, C.E.; DOWDOU, R.H. Hydrologic management: nutrients. In: PAGE, A.L.; GEASON, T.L.; SMITH, J.E.; ISKANDAR, J.K.; SOMMERS, L.E. Utilization od municipal wastewater and sludge on land. Riverside: University of California, 1983. p.79-103.

LINDSAY, W.L.; NORVELL, W.A. Development of DTPA soil test zinc, iron manganese and copper. Soil Science Society American Journal, v.42, p.421-428, 
LOGAN, T.J.; CHANEY, R.L. Utilization of municipal wastewater and sludge on land metals. In: PAGE, A.L.; GLEASON, T.L.; SMITH JR; J.E.; ISKANDAR, I.K.; SOMMERS; L.E. Proceedings of the 1983 workshop on utilization of municipal wastewater and sludge on land. Riversid: University of California, 1983, p.235323.

LOGAN, T.J.; LINDSAY, B.J.; GOINS, L.E.; RYAN, L.A. Field assessment of sludge metal bioavailability to crops: sludge rate response. Journal of Environmental Quality, v.26, n.2, p.534-550, 1997.

MAcGRATH, S.P.; CEGARRA, J. Chemical extractability of metals during and after long-term application of sewage sludge to soil. Journal of Soil Science, v.43, p.313-321, 1992.

MALAVOLTA, E. Fertilizantes e seu impacto ambiental: metais pesados, mitos, mistificação e fatos. São Paulo: ProduQuímica, 1994. 153p.

MALAVOLTA, E.; VITTI, G.C.; OLIVEIRA, S.A. Avaliação do estado nutricional das plantas: princípios e aplicações. 2. ed., Piracicaba: Potafos, 1997. 319p.

MARQUES, M.O. Efeitos da aplicação de lodo de esgoto na produtividade e qualidade da cana-de-açúcar. Piracicaba, 1990. 164p. Tese (Doutorado) - Escola Superior de Agricultra "Luiz de Queiroz", Universidade de São Paulo.

MARQUES. M.O. Incorporação de lodo de esgoto em solos cultivados com cana-deaçúcar. Jaboticabal, 1996. 111p. Tese (Livre Docência) - Faculdade de Ciências Agrárias e Veterinárias, Universidade Estadual Paulista "Julio de Mesquita Filho". 
MATTIAZZO-PREZOTTO, M.E. Química ambiental e agronomia. In: REUNIÃO BRASILEIRA DE FERTILIDADE DO SOLO E NUTRIÇÃO DE PLANTAS, 22.,Piracicaba, 1992. Anais. Piracicaba: Fundação Cargill, 1992. P.157-178.

MEHLICH, A. Mehlich-3 soil test extraction: A modification of Mehlich-2. Communications of Soil Science and Plant Analysis, v.15, p. 1409-1416, 1984.

MELO, W.J.; MARQUES, M.O; SANTIAGO, G.; CHELLI, R.A.; LEITE, S.A.S. Efeito de doses crescentes de lodo de esgoto sobre frações da matéria orgânica e CTC de um Latossolo cultivado com cana-de-açúcar. Revista Brasileira de Ciência do Solo, v.18, n.3, p.449-445, 1994.

MELO, W.J.; MARQUES, M.O.; SILVA, F.C.; BOARETTO, A.E. Uso de resíduos sólidos urbanos na agricultura e impactos ambientais (compact disc) In: CONGRESSO BRASILEIRO DE CIÊNCIA DO SOLO, 26., Rio de Janeiro, 1997. Anais: Trabalhos. Rio de Janeiro: SBCS, 1997.

MENGEL, K., KIRKY, E. A. Potassium. In: Principles of plant nutrition. Worblaufen-Bern/Switzerland: International Potash Institute, 1982. 655 p.

MULCHI, C.L.; ADAMU, C.A.; BELL, P.F.; CHANEY, R.L. Residual heavy metal concentrations in sludge-amended coastal plain soils- I. Comparason of extractants. Communications in Soil Science and Plant Analysis, v.22, p.919-941, 1991.

OLIVEIRA, F.C. Metais pesados e formas nitogenadas em solos tratados com lodo de esgoto. Piracicaba, 1995. 90p. Dissertação (Mestrado) - Escola Superior de Agricultura "Luiz de Queiroz", Universidade de São Paulo. 
OLIVEIRA, F.C. Disposição de lodo de esgoto e composto de lixo num Latossolo Vermelho-amarelo cultivado com cana-de-açúcar. Piracicaba, 2000. 247p. Tese (Doutorado) - Escola Superior de agricultura "Luiz de Queiroz", Universidade de São Paulo.

OLIVEIRA, F.C; MARQUES, M.O; BELLINGIERI, P.A.; PERECIN, D. Lodo de esgoto como fonte de macronutrientes para a cultura do sorgo granifero. Scientia Agricola, v.52, n.2, p.360-367, 1995.

PARR, J.F.; WILLSON, G.B. Recycling wastes to improve soil productivity. Hort Science, v. 15, n.2, p.162-166, 1980.

PEREIRA JUNIOR., A.B.; VALIM, M.C.A.; SOUZA, J.L.; GONÇALVES, R.F. Utilização de lodo de esgoto gerado em processo anaeróbio tipo tanque inhoff como insumo agrícola para a cultura do milho (Zea mays L.). In: COGRESSO BRASILEIRO DE ENGENHARIA SANITÁRIA E AMBIENTAL, 19.,Doz do Iguaçu, 1997. Anais. Rio de Janeiro: ABES, 1997. p.462-475.

PIETZ, R.I.; CARLSON, C.R.; PETERSON JÚNIOR, J.R.; ZENZ, D.R.; LUE-HING, C. Application of sewage sludge and other amendments to coal refuse material: III effects on percocolate water composition. Journal of Environmental Quality, v. 18, p. 174-179, 1989.

PIRES, A.M.M. Disponibilidade de $\mathrm{Zn}$ e $\mathrm{Cu}$ adicionados a solos via lodo de esgoto para plantas de arroz. Piracicaba, 1998. 55p. Tese (Mestrado) - Escola Superior de Agricultura "Luiz de Queiroz", Universidade de São Paulo.

PPI. 1978. Manual de Fertilidade do solo. Trad. E adap. De LOPES, A.S. Anda e POTAFOS. São Paulo, 156 p. 
RAIJ, B. van; QUAGGIO, J.A. Métodos de análise de solo para fins de fertilidade. Campinas: IAC, 1983. 40p. (IAC. Boletim Técnico, 81).

RAIJ, B. van; SILVA, N.M.; BATAGLIA, O.C.; QUAGGIO, J.A.; HIROCE, R.; CATARELLA, H.; BELLINAZZI JUNIOR, R.; DECHEN, A. R.; TRANI, P.E. Recomendação de adubação e calagem para o Estado de São Paulo. Campinas: Instituto Agronômico, 1996. 285p. (IAC. Boletim técnico, 100)

RAPPAPORT, B.D.; MARTENS, D.C.; RENAU JR., R.B.; SIMPSON, T.W. Metal availability in sludge-amended soils with elevated metals levels. Journal of Environmental Quality, v.17, n.1, p.42-47, 1988.

ROCA, J.; POMARES, F. Prediction of available heavy metals by six chemical extractants a sewage sludge-amended soil. Communications in Soil Science and Plant Analysis, v. 22, n.19-20, p.2129-2136, 1991.

ROS, C.O. da; AITA, C.; CERETTA, C.A.; FRIES, M.R. Lodo de esgoto: efeito imediato no milheto e residual na associação aveia-ervilhaca. Revista Brasileira de Ciência do Solo, v.17, n.3, p.257-261, 1993.

SABEY, B.R. The use of sewage as a fertilizer. In: BEWICK, M.W. Hand book of Organic Waste Conversion. Nostrand Reinhold, 1980. p.72-107.

SARRUGE, J.R.; HAAG, H.P. Análises químicas em plantas. Piracicaba, ESALQ, 1974. 56p.

SAUERBECK, D.R.; STYPEREK, P. Evaluation of methods for assessing the Cd and $\mathrm{Zn}$ availability from different soils and sources. In: LESCHBER, R.; DAVIES, $\mathrm{R}$. D.; L'HERMTTE, P. (Ed.). Chemical Methods for Assessind Biovailability Metal in Sludge and Soils. London: Elsevier, 1985. p. 49-66. 
SHUMAN, L.M. Adsoption of $\mathrm{Zn}$ by $\mathrm{Fe}$ and $\mathrm{Al}$ hydrous oxides as influenced by aging and pH. Soil Science Society American Journal, v.41, p. 70-76, 1977.

SHUMAN, L.M. Effect of ionic strength and anions on zinc adsorption by two soils. Soil Science Society of Amarica Jounal, v.50, 1438-1442, 1986.

SILVA, F.C. Uso do lodo de esgoto: efeitos em fertilidade do solo e qualidade da canade-açúcar. Piracicaba, 1995. 159p. Tese (Doutorado) - Escola Superior de Agricultura "Luiz de Queiroz", Universidade de São Paulo

SILVA, F.C.; BOARETTO, A.E.; BERTON, R.S.; ZOTELLI, H.B.; PEXE, C.A.; MENDONÇA, E. Cana-de-açúcar cultivada em solo adubado com lodo de esgoto: nutrientes, metais pesados e produtividade. Pesquisa Agropecuária Brasileira, v.13, n.1, p.1-8, 1998.

SILVA, L.S.; CAMARGO, F.A. de O.; CERETTA, C.A. Composição da fase sólida orgânica do solo. In: MEURER, E.J. Fundamentos de Química do Solo. Porto Alegre: Genesis, 2000, p. 45-62.

SIMEONI, L.A.; BARBARICK, K.A.; SABEY, B.R. Effect of samall-scale composting of sewage sludge on heavy metal availability to plants. Journal of Environmental quality, v.13, n.2, p.264-268, 1984.

SINGH, R.S.; SINGH, R.P.; RAI, R.K. Relationship between soil test methods and uptake of copper and zinc by grasses on polluted soils. Communications in Soil Science and Plant Analysis, v. 25, n. 9-10, p.1313-1320, 1994.

SLOAN, J.J.; BASTA, N.T. Remediation of acid soils by using alkaline biosolids. Journal of Environmental Quality, v.24, p. 1097-1103, 1995. 
SOLTANPOUR, P.N.; JONES JUNIOR, J.; WORKMAN, S.M. Optical emission spectrometry. In: PAGE, A.L.; MILLER, R.H.: KEENEY, D.R. (Ed). Methods of soil analysis. Madison:ASA,SSSA, 1982. P.29-65.

SOMMERS, L.; VOLK, V.V.; GIORDANO, P.M.; SOPPER, W.E.; BASTIAN, R. Effects of soil properties on accumulation of trace elements by crops. In: PAGE, A.L.; LOGAN, T.J.; RYAN, J.A. Land application of sludge - food chain implications. Chelsea: Lewis Publishers, 1987. Cap.2, p.5-24.

SOUZA, W.J.O. de; MELO, W.J. de; MARQUES, M.O.; TSUTIYA, M.T. Efeito da aplicação de lodo de esgoto sobre a produção de matéria seca e rendimento de grãos pela cultura do milho em dois tipos de solo. In: SEMINÁRIO SOBRE GERENCIAMENTO DE BIOSSÓLIDOS DO MERCOSUL, 1, Curitiba, 1998. Anais. Curitiba: SANEPAR; ABEAS, 1998. P.313-314.

STARK, S.A.; CLAPP, C.E. Residual nitrogen availability from soils treated with sewage sludge in a field experimente. Journal of Environmental Quality, v.9, n.3, p.505-512, 1980.

STREET, J.J.; LINDSAY, W.L.; SABEY, B.R. Solubility and plant uptake of cadmium in soils amended with cadmium and sewage sludge. Journal of Environmental Quality, v.6, n.1, p.72-77, 1977.

SUI, Y.; THOMPSON, M.L. Phospurus sorption, desorption, and buffering capaciry in a biosolids-amented mollisol. Soil Science American Journal, v.64, p. 164-169, 2000 .

TAYLOR, R.W.; IBEABUCHI, I.O.; SISTANI, K.R.; SHUFORD, J.W. Heavy metal concentration in forage and extractabilility from some acid mine spoils. Water, Air and Soil Pollution, v.68, p.363-372, 1993. 
TEDESCO, M.J.; VOLKWEISS, S.J.; BOHNEN, H. Análises de solo, plantas e outros materiais. 2. ed. Porto Alegre: Universidade Federal do Rio Grande do Sul, 1995. 174 p. (Boletim técnico: 5).

TISDALE, S.L.; NELSON,W.L.; BEATON, J.D. Soil Fertility and Fertilizers, 4.ed. New York: Macmillan,1985, 754p.

TRAN, T.S.; GIROUX, M.; GUILBEAUT, J.; AUDES, P. Evaluation of Mehlich-III extractant to estimate the available $\mathrm{P}$ in Quebec Soils. Communications Soil Science Plant Analysis, v.21, p.1-28, 1990.

USDA. United States Departament of Agriculture. Report and Recommendations on Organic Forming. Washington: D.C.U.S, Government, 1980. 94p. (620-220/3641).

U. S. ENVIRONMENTAL PROTECTION AGENCY 1995. EPA/832-B-93-005. A Guide to the Biosolids Risk Assessments for the EPA Part 503 Rule. Fed. Reg. p. 143 p.

VALADARES, J.M.A.S.; GAL, M.; MILGELGRIN, V.; PAGE, A.I. Some heavy metais in soils treated with sewage sludge, their effects on yield, and their uptake by plants. Journal of Environmental Quality, v.12, p.49-57, 1983.

VAZ, L.M.S. Crescimento inicial, fertilidade do solo e nutrição de um povoamento de Eucalyptus grandis fertilizado com biossólido. Piracicaba, 2000. 41p. Tese (Mestrado) - Escola Superior de Agricultura "Luiz de Queiroz", Universidade de São Paulo.

VITTI, G.C. Avaliação e interpretação do enxofre no solo e na planta. Jaboticabal: FUNEP, 1988. 37p. 
APÊNDICE 
Apêndice 1. Valor F, probabilidade $>\mathrm{F}$ e coeficiente de variação (C.V.) das análises de variância $^{(1)}$ realizadas à partir das variáveis determinadas no solo, 30 dias após aplicação de lodo de esgoto. Valores para a causa de variação "dose de lodo de esgoto"

\begin{tabular}{|c|c|c|c|}
\hline Causa de variação & Valor F & Probabilidade $>\mathrm{F}$ & C.V. \\
\hline $\mathrm{pH}$ & 21,06 & 0,00001 & 3,08 \\
\hline Matéria orgânica (MO) & 45,06 & 0,00001 & 8,09 \\
\hline Alumínio trocável (Al) & 15,26 & 0,00001 & 85,89 \\
\hline $\begin{array}{l}\text { Porcentagem de saturação por } \\
\text { alumínio }(m)\end{array}$ & 14,28 & 0,00001 & 88,61 \\
\hline Fósforo disponível (P) & 36,76 & 0,00001 & 20,90 \\
\hline $\mathrm{S}$ disponível $\left(\mathrm{S}-\mathrm{SO}_{4}\right)$ & 37,18 & 0,00001 & 38,52 \\
\hline Potássio trocável (K) & 4,81 & 0,00007 & 18,27 \\
\hline Cálcio trocável (Ca) & 38,05 & 0,00001 & 12,08 \\
\hline Magnésio trocável (Mg) & 9,67 & 0,00001 & 10,13 \\
\hline Sódio trocável (Na) & 42,32 & 0,00001 & 21,45 \\
\hline Soma de bases (SB) & 36,36 & 0,00001 & 10,24 \\
\hline $\mathrm{H}+\mathrm{Al}$ & 15,04 & 0,00001 & 12,70 \\
\hline $\begin{array}{l}\text { Capacidade de troca de cátions } \\
(\mathrm{CTCpH} 7)\end{array}$ & 64,95 & 0,00001 & 6,99 \\
\hline $\begin{array}{l}\text { Capacidade de troca de cátions } \\
\text { (CTC efetiva) }\end{array}$ & 36,27 & 0,00001 & 10,42 \\
\hline $\begin{array}{l}\text { Porcentagem de saturação por } \\
\text { bases (V) }\end{array}$ & 1,38 & 0,2400 & 10,34 \\
\hline
\end{tabular}


Apêndice 2. Valor F, probabilidade $>\mathrm{F}$ e coeficiente de variação (C.V.) das análises de variância ${ }^{(1)}$ realizadas à partir das variáveis ferro, manganês, zinco e cobre determinadas no solo por diferentes extratores. Valores para a causa de variação "dose de lodo de esgoto"

\begin{tabular}{|c|c|c|c|}
\hline Causa de variação & Valor d e F & Probabilidade $>$ F & C.V. \\
\hline & & DTPA a pH 7 & \\
\hline Ferro $(\mathrm{Fe})$ & 120,91 & 0,00001 & 12,61 \\
\hline Manganês (Mn) & 24,91 & 0,00001 & 22,23 \\
\hline Zinco (Zn) & 1291,92 & 0,00001 & 7,53 \\
\hline \multirow[t]{2}{*}{ Cobre $(\mathrm{Cu})$} & 244,73 & 0,00001 & 5,27 \\
\hline & & Mehlich- 3 & \\
\hline Ferro $(\mathrm{Fe})$ & 209,18 & 0,00001 & 7,62 \\
\hline Manganês (Mn) & 383,21 & 0,00001 & 3,67 \\
\hline Zinco $(Z n)$ & 455,55 & 0,00001 & 11,51 \\
\hline \multirow[t]{2}{*}{ Cobre $t(\mathrm{Cu})$} & 44,08 & 0,00001 & 15,01 \\
\hline & & $\mathrm{HCl} \mathrm{0,1} \mathrm{mol} \mathrm{L}^{-1}$ & \\
\hline Ferro $(\mathrm{Fe})$ & 72,71 & 0,00001 & 22,96 \\
\hline Manganês (Mn) & 151,08 & 0,00001 & 7,23 \\
\hline Zinco $(Z n)$ & 669,14 & 0,00001 & 10,66 \\
\hline Cobre $(\mathrm{Cu})$ & 210,64 & 0,00001 & 10,36 \\
\hline
\end{tabular}

(1) Graus de liberdade: Dose de lodo de esgoto = 5; Resíduo = 90; Total 95. 
Apêndice 3. Valor F, probabilidade $>F$ e coeficiente de variação (C.V.) das análises de variância $^{(1)}$ realizadas à partir dos resultados obtidos para as variáveis ferro, manganês, cobre e zinco extraídos por diferentes extratores

\begin{tabular}{|c|c|c|c|}
\hline Causa de variação & Valor d e F & Probabilidade $>\mathrm{F}$ & C.V. \\
\hline & & Ferro & \\
\hline Dose de lodo & 894,51 & 0,00101 & 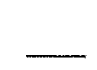 \\
\hline Método & 4497,94 & 0,00001 & $\ldots$ \\
\hline \multirow[t]{3}{*}{ Dose $\mathrm{x}$ método } & 289,58 & 0,00001 & $\underline{-}$ \\
\hline & & & 5,05 \\
\hline & & Manganês & \\
\hline Dose de lodo & 108,10 & 0,00101 & 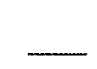 \\
\hline Método & $40,86,25$ & 0,00001 & $\underline{-}$ \\
\hline \multirow[t]{3}{*}{ Dose $\mathrm{x}$ método } & 45,25 & 0,00001 & $\underline{-}$ \\
\hline & & & 6,24 \\
\hline & & Cobre & \\
\hline Dose de lodo & 94,86 & 0,00101 & $\underline{-}$ \\
\hline Método & 95,85 & 0,00001 & - \\
\hline \multirow[t]{3}{*}{ Dose $\mathrm{x}$ método } & 15,48 & 0,00001 & $\underline{-}$ \\
\hline & & & 9,29 \\
\hline & & Zinco & \\
\hline Dose de lodo & 1998,36 & 0,00101 & - \\
\hline Método & 624,56 & 0,00001 & $\underline{-}$ \\
\hline \multirow[t]{2}{*}{ Dose $\mathrm{x}$ método } & 53,20 & 0,00001 & $\underline{-}$ \\
\hline & & & 5,59 \\
\hline
\end{tabular}


Apêndice 4. Graus de Liberdade Valor F, probabilidade $>$ F e coeficiente de variação (C.V.) das análises de variância realizadas à partir dos resultados obtidos para as variáveis Matéria seca da parte aérea das plantas e para o nitrogênio acumulados pelas plantas

\begin{tabular}{|c|c|c|c|}
\hline Causa de variação & G.L. & Valor d e F & Probabilidade $>F$ \\
\hline & \multicolumn{3}{|c|}{ Produção de matéria seca } \\
\hline K & 1 & 51,68 & 0,00001 \\
\hline $\mathrm{P}$ & 1 & 428,13 & 0,00001 \\
\hline Lodo & 5 & 76,09 & 0,00001 \\
\hline $\mathrm{K} \times \mathrm{P}$ & 5 & 10,98 & 0,00181 \\
\hline $\mathrm{K} \times$ lodo & 5 & 2,83 & 0,02166 \\
\hline P x lodo & 5 & 0,92 & 0,52238 \\
\hline $\mathrm{K} \times \mathrm{P} \times$ lodo & 5 & 1,36 & 0,24990 \\
\hline Total & 95 & & \\
\hline \multicolumn{4}{|l|}{ C.V. $(12,33 \%)$} \\
\hline & \multicolumn{3}{|c|}{ Nitrogênio acumulado } \\
\hline $\mathrm{K}$ & 1 & 6,38 & 0,01315 \\
\hline $\mathrm{P}$ & 1 & 10,69 & 0,00202 \\
\hline Lodo & 5 & 89,62 & 0,00001 \\
\hline$K \times P$ & 5 & 5,12 & 0,02510 \\
\hline $\mathrm{K} \times$ lodo & 5 & 6,09 & 0,00021 \\
\hline P x lodo & 5 & 2,58 & 0,03282 \\
\hline $\mathrm{K} \times \mathrm{P} \times$ lodo & 5 & 2,87 & 0,02016 \\
\hline Total & 95 & & \\
\hline C.V. $(15,78 \%)$ & & & \\
\hline
\end{tabular}


Apêndice 5. Graus de Liberdade Valor F, probabilidade $>\mathrm{F}$ e coeficiente de variação (C.V.) das análises de variância realizadas à partir dos resultados obtidos para as variáveis Fósforo e Enxofre acumulados pelas plantas

\begin{tabular}{|c|c|c|c|}
\hline Causa de variação & G.L. & Valor d e F & Probabilidade $>F$ \\
\hline & \multicolumn{3}{|c|}{ Fósforo } \\
\hline $\mathrm{K}$ & 1 & 1,08 & 0,30184 \\
\hline $\mathbf{P}$ & 1 & 453,13 & 0,00001 \\
\hline Lodo & 5 & 77,48 & 0,00001 \\
\hline$K \times P$ & 5 & 2,17 & 0,14169 \\
\hline $\mathrm{K} \times$ lodo & 5 & 4,54 & 0,00149 \\
\hline $\mathrm{P} \times$ lodo & 5 & 0,99 & 0,56853 \\
\hline $\mathrm{K} \times \mathrm{P} \times$ lodo & 5 & 1,00 & 0,42317 \\
\hline Total & 95 & & \\
\hline \multicolumn{4}{|l|}{ C.V. $(15,98 \%)$} \\
\hline & \multicolumn{3}{|c|}{ Enxofre } \\
\hline $\mathrm{K}$ & 1 & 98,98 & 0,00001 \\
\hline $\mathrm{P}$ & 1 & 74,38 & 0,00001 \\
\hline Lodo & 5 & 110,26 & 0,00001 \\
\hline $\mathrm{K} \times \mathrm{P}$ & 5 & 8,78 & 0,00438 \\
\hline $\mathrm{K} \times$ lodo & 5 & 3,71 & 0,00512 \\
\hline P $x$ lodo & 5 & 1,92 & 0,10160 \\
\hline $\mathrm{K} \times \mathrm{P} \times$ lodo & 5 & 0,68 & 0,64380 \\
\hline Total & 95 & & \\
\hline C.V. $(21,50 \%)$ & & & \\
\hline
\end{tabular}


Apêndice 6. Graus de Liberdade Valor F, probabilidade > F e coeficiente de variação (C.V.) das análises de variância realizadas à partir dos resultados obtidos para as variáveis Potássio e Cálcio acumulados pelas plantas

\begin{tabular}{|c|c|c|c|}
\hline Causa de variação & G.L. & Valor d e F & Probabilidade $>\mathrm{F}$ \\
\hline & \multicolumn{3}{|c|}{ Potássio } \\
\hline $\mathrm{K}$ & 1 & 903,35 & 0,00001 \\
\hline $\mathrm{P}$ & 1 & 15,27 & 0,00043 \\
\hline Lodo & 5 & 13,13 & 0,00001 \\
\hline $\mathrm{K} \times \mathrm{P}$ & 5 & 9,03 & 0,00395 \\
\hline $\mathrm{K} \times$ lodo & 5 & 0,78 & 0,56804 \\
\hline P $x$ lodo & 5 & 1,11 & 0,36444 \\
\hline $\mathrm{K} \times \mathrm{P} \times$ lodo & 5 & 2,43 & 0,04260 \\
\hline Total & 95 & & \\
\hline \multicolumn{4}{|l|}{ C.V. $(13,41 \%)$} \\
\hline & \multicolumn{3}{|c|}{ Cálcio } \\
\hline $\mathrm{K}$ & 1 & 25,48 & 0,00004 \\
\hline $\mathrm{P}$ & 1 & 37,26 & 0,00001 \\
\hline Lodo & 5 & 52,58 & 0,00001 \\
\hline $\mathrm{K} \times \mathrm{P}$ & 5 & 0,21 & 0,64994 \\
\hline $\mathrm{K} \times$ lodo & 5 & 2,89 & 0,01953 \\
\hline P $x$ lodo & 5 & 1,30 & 0,27382 \\
\hline $\mathrm{K} \times \mathrm{P} \times$ lodo & 5 & 0,21 & 0,95442 \\
\hline Total & 95 & & \\
\hline C.V. $(22,35 \%)$ & & & \\
\hline
\end{tabular}


Apêndice 7. Graus de Liberdade Valor F, probabilidade $>$ F e coeficiente de variação (C.V.) das análises de variância realizadas à partir dos resultados obtidos para as variáveis Magnésio e Ferro acumulados pelas plantas

\begin{tabular}{lccc}
\hline \multicolumn{1}{c}{ Causa de variação } & G.L. & Valor d e F & Probabilidade $>$ F \\
\hline & & \multicolumn{3}{c}{ Magnésio } \\
K & 1 & 79,70 & 0,00001 \\
P & 1 & 53,85 & 0,00001 \\
Lodo & 5 & 77,36 & 0,00001 \\
K x P & 5 & 1,07 & 0,30426 \\
K x lodo & 5 & 7,36 & 0,00006 \\
P x lodo & 5 & 0,66 & 0,66107 \\
K x P x lodo & 5 & 0,40 & 0,84653 \\
Total & 95 & & \\
C.V. (17,85 \%) & & & \\
& & & \\
K & 1 & 0,29 & 0,59722 \\
P & 1 & 6,50 & 0,01240 \\
Lodo & 5 & 5,42 & 0,00047 \\
K x P & 5 & 0,06 & 0,80450 \\
K x lodo & 5 & 1,33 & 0,25987 \\
P x lodo & 5 & 0,71 & 0,61698 \\
K x P x lodo & 5 & 0,22 & 0,95153 \\
Total & 95 & & \\
C.V. (65,32 \%) & & & \\
\hline
\end{tabular}


Apêndice 8. Graus de Liberdade Valor F, probabilidade $>$ F e coeficiente de variação (C.V.) das análises de variância realizadas à partir dos resultados obtidos para as variáveis Manganês e Cobre acumulados pelas plantas

\begin{tabular}{|c|c|c|c|}
\hline Causa de variação & G.L. & Valor d e F & Probabilidade $>\mathrm{F}$ \\
\hline & \multicolumn{3}{|c|}{ Manganês } \\
\hline $\mathrm{K}$ & 1 & 0,03 & 0,85703 \\
\hline$P$ & 1 & 30,78 & 0,00001 \\
\hline Lodo & 5 & 75,14 & 0,00001 \\
\hline$K \times P$ & 5 & 0,34 & 0,56695 \\
\hline $\mathrm{K} \times$ lodo & 5 & 2,62 & 0,03076 \\
\hline $\mathrm{P} \times$ lodo & 5 & 0,89 & 0,50531 \\
\hline $\mathrm{K} \times \mathrm{P} \times$ lodo & 5 & 0,48 & 0,79320 \\
\hline Total & 95 & & \\
\hline \multicolumn{4}{|l|}{ C.V. $(32,63 \%)$} \\
\hline & \multicolumn{3}{|c|}{ Cobre } \\
\hline $\mathrm{K}$ & 1 & 1,45 & 0,293789 \\
\hline$P$ & 1 & 0.75 & 0,60309 \\
\hline Lodo & 5 & 12,93 & 0,00001 \\
\hline $\mathrm{K} \times \mathrm{P}$ & 5 & 1,76 & 0,31275 \\
\hline $\mathrm{K} \times$ lodo & 5 & 1,28 & 0,28113 \\
\hline $\mathrm{P} \times$ lodo & 5 & 0,69 & 0,60336 \\
\hline $\mathrm{K} \times \mathrm{P} \times$ lodo & 5 & 1,31 & 0,26787 \\
\hline Total & 95 & & \\
\hline C.V. (\%) & & & \\
\hline
\end{tabular}


Apêndice 9. Graus de Liberdade Valor F, probabilidade $>$ F e coeficiente de variação (C.V.) das análises de variância realizadas à partir dos resultados obtidos para a variável Zinco acumulado pelas plantas

\begin{tabular}{lccc}
\hline \multicolumn{1}{c}{ Causa de variação } & G.L. & Valor d e F & Probabilidade $>$ F \\
\hline K & \multicolumn{3}{c}{ Zinco } \\
P & 1 & 25,82 & 0,00003 \\
Lodo & 1 & 1,64 & 0,20195 \\
K x P & 5 & 153,14 & 0,00001 \\
K x lodo & 5 & 1,26 & 0,26457 \\
P x lodo & 5 & 6,20 & 0,00019 \\
K x P x lodo & 5 & 0,86 & 0,51141 \\
Total & 5 & 0,86 & 0,51193 \\
C.V. $(28,10 \%)$ & 95 & & \\
\hline
\end{tabular}

